UNIVERSIDADE DE SÃO PAULO

ESCOLA DE EDUCAÇÃO FÍSICA E ESPORTE DE RIBEIRÃO PRETO

CAMILA MOTTA ESTEVAM

Representação dos Jogos dos Povos Indígenas na mídia brasileira

RIBEIRÃO PRETO

2020 
CAMILA MOTTA ESTEVAM

\title{
Representação dos Jogos dos Povos Indígenas na mídia brasileira
}

\author{
Versão Corrigida
}

Dissertação apresentada ao Programa de PósGraduação em Educação Física e Esporte da Escola de Educação Física e Esporte de Ribeirão Preto da Universidade de São Paulo, para Exame de Defesa nível mestrado.

Linha de Pesquisa: Dimensões pedagógicas e socioculturais envolvidas no processo de desenvolvimento da carreira esportiva de atletas, treinadores e consumidores.

Orientador: Prof. Dr. Claudio Miranda Rocha

RIBEIRÃO PRETO 
Autorizo a reprodução e divulgação total ou parcial deste trabalho, por qualquer meio convencional ou eletrônico, para fins de estudo e pesquisa, desde que citada a fonte.

Estevam, Camila Motta

Representação dos Jogos dos Povos Indígenas na mídia brasileira. Ribeirão Preto, 2020.

88 p. : il. ; $30 \mathrm{~cm}$

Dissertação de Mestrado, apresentada à Escola de Educação Física e Esporte de Ribeirão Preto/USP. Área de concentração: Gestão Esportiva.

Orientador: Rocha, Claudio Miranda.

1. Jogos. 2. Jogos dos povos indígenas. 3. Mídia. 
Nome: Camila Motta Estevam

Título: Representação dos Jogos dos Povos Indígenas na mídia brasileira

Dissertação apresentada ao Programa de PósGraduação em Educação Física e Esporte da Escola de Educação Física e Esporte de Ribeirão Preto da Universidade de São Paulo, para obtenção do título de mestre nível em Educação Física.

Aprovado em:

Banca Examinadora

Profa. Dra.

Instituição:

Julgamento:

Profa. Dra.

Instituição:

Julgamento:

Prof. Dr.

Instituição:

Julgamento: 


\section{AGRADECIMENTOS}

À Nossa Senhora do Perpétuo Socorro ao qual sou devota.

À minha família por todo apoio e incentivo. Ao meu esposo Tiago pela paciência, incentivo e compreensão em todos os processos desta caminhada.

Aos meus amigos e amigas de mestrado, em especial Taislaine por todo apoio e tempo dedicados com todo carinho.

Gratidão ao meu orientador Prof. Dr. Claudio Miranda, que mesmo morando em outro país, esteve comigo a todo momento, posicionando-se sempre de forma cordial, positiva e segura em todas as fases da elaboração deste projeto.

Ao Prof. Dr. Rafael Pombo pela gentileza em aceitar o convite da minha banca de qualificação e pela compreensão referentes às mudanças ocorridas no decorrer desta pesquisa. À Profa. Dra. Marina Vinha pela gentileza em aceitar o convite para a composição da minha banca de qualificação, por seus apontamentos extremamente necessários para o desenvolvimento desta pesquisa e por sempre estar disponível em contribuir no que fosse necessário. 


\section{RESUMO}

ESTEVAM, Camila Motta. Representação dos Jogos dos Povos Indígenas na mídia brasileira. 2020. 88 f. Dissertação (Mestrado em Educação Física e Esporte) - Escola de Educação Física e Esporte de Ribeirão Preto, Universidade de São Paulo, Ribeirão Preto, 2020.

O objetivo desta pesquisa é compreender como a mídia brasileira tem representado os Jogos dos Povos Indígenas (JPI). Estes jogos foram criados com o apoio do extinto Ministério de Estado do Esporte e do Comitê Intertribal (ITC). Os Jogos dos Povos Indígenas é considerado como um evento não mega e ao longo de suas 12 edições, acumularam um patrimônio cultural diverso que oportuniza a pesquisa sobre seus legados de forma única. Os JPI podem ser considerados como evento Entender com a mídia brasileira representa os JPI pode trazer benefícios para as populações indígenas, que deveriam ser os principais beneficiários de tal evento. Trata-se de uma pesquisa qualitativa. Como método de coleta de dados optou-se pela técnica de análise de conteúdo. Os meios de comunicação e fontes utilizados foram jornais, revistas, arquivos e internet que abordaram as 12 edições dos Jogos dos Povos Indígenas. Resultados desta análise mostram que a mídia possui pouco conhecimento e interesse no aprofundamento de temáticas indígenas. $\mathrm{O}$ tratamento dos dados mostrou, que além do despreparo destes meios de comunicação, as reportagens muitas vezes estavam arraigadas de preconceito. Embora a expressão "jogos" usada para classificar os JPI, tenha sido a mais utilizada, dentro do contexto das matérias ela estava mais ligada a um conceito de esporte padronizado do que o significado do jogo para estes povos.

Palavras-chave: Jogos. Jogos dos povos indígenas. Mídia. 


\begin{abstract}
ESTEVAM, Camila Motta. Representation of Indigenous Peoples Games in the Brazilian media. 2020. 88 f. Dissertação (Mestrado em Educação Física e Esporte) - Escola de Educação Física e Esporte de Ribeirão Preto, Universidade de São Paulo, Ribeirão Preto, 2020.

The purpose of this study is to describe how the Brazilian media has represented the Indigenous People Games (IPG). These games are supported by the Ministry of Sport and the Intertribal Committee (IC). Throughout its 12 editions, the Games have accumulated a diverse cultural heritage that makes it possible to uniquely research their legacies. Understanding how the Brazilian media represents the IPG can bring benefits to indigenous populations, who should be the main beneficiaries of such an event. It is a qualitative research. The content analysis technique was chosen to analyze the data. The media and sources used were newspapers, magazines, archives and the internet that addressed the 12 editions of the Indigenous People Games. Results of this analysis show that the media has little knowledge or interest in deepening indigenous themes. The treatment of the data showed that, in addition to the unpreparedness of these media, the reports were often fraught with prejudice. Although the term "games" used to classify IPG was the most widely used term, within the context of the material it was more linked to a concept of standardized sport than the meaning of the game to these people.
\end{abstract}

Keywords: Games. Indigenous peoples games. Media. 


\section{LISTA DE QUADROS}

Quadro 1 - Número de reportagens por meio de comunicação...........................51

Quadro 2 - Número de reportagens por edição........................................53 


\section{LISTA DE FIGURAS}

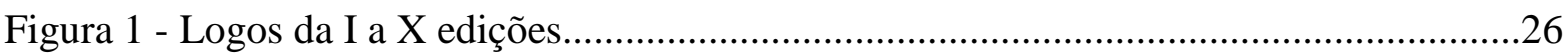

Figura 2 - Esquema explicativo sobre as terminologias indígena, autóctone, primitivo e

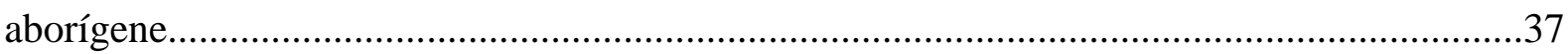

Figura 3- Esquema de desenvolvimento de uma

análise. .48 


\section{LISTA DE GRÁFICOS}

Gráfico 1 - Frequência das conceituações dos JPI realizadas nas reportagens...............57

Gráfico 2 - Número de reportagens por edição.......................................65 


\section{SUMÁRIO}

1 INTRODUÇÃ̃

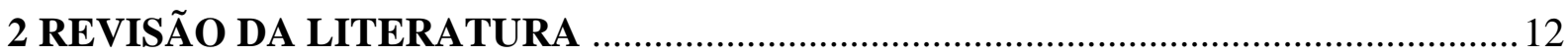

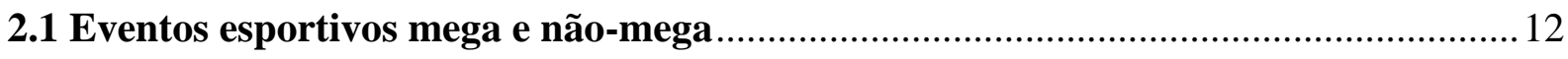

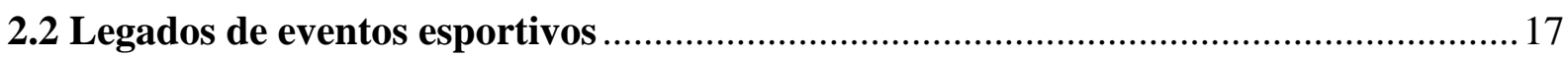

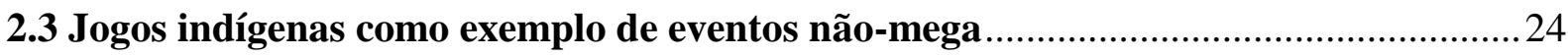

2.3.1 A importância do legado de participação para os povos indígenas .........................28

2.3.2 A importância do legado cultural para os povos indígenas ................................... 30

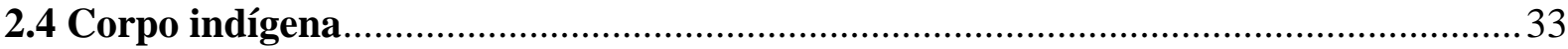

2.4.1 As práticas corporais das etnias brasileiras: quais jogos se jogam? ...................... 38

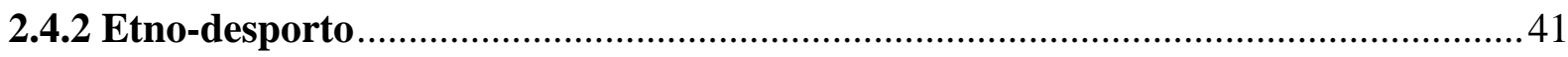

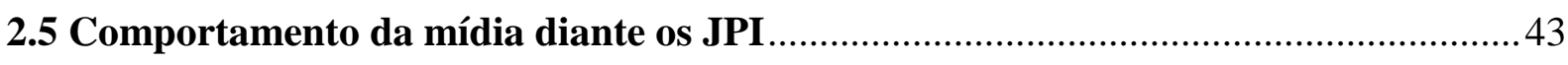

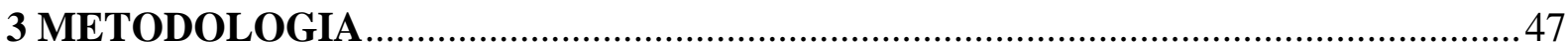

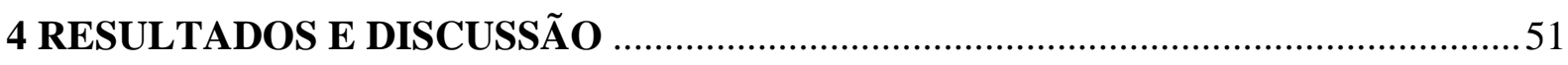

4.1 Temas principais e secundários abordados nas reportagens …..............................53

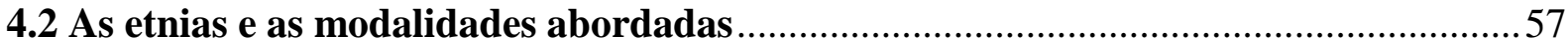

4.3 A classificação dos JPI e a visão sobre os povos indígenas e sua cultura. .................. 60

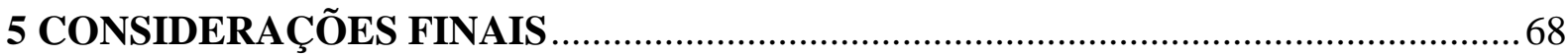

5.1 Limitações e perspectivas para pesquisas futuras ............................................... 70

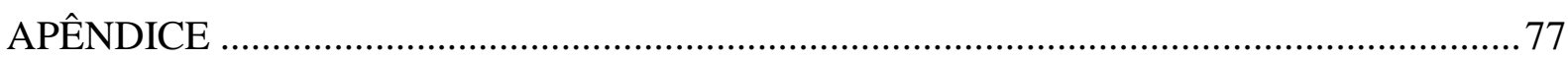

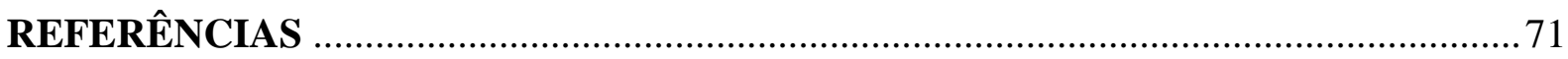


O interesse do homem pelas variedades de jogos surge na antiguidade e perdura até os tempos modernos. Com relação aos eventos esportivos, é possível dizer que sua relevância surgiu inicialmente pela necessidade humana de interagir uns com os outros; porém, atualmente esta relevância está muito ligada a interesses políticos, de mercado ou de administradores (POIT, 2006). Neste sentido, não é surpreendente que pesquisas relacionadas a eventos esportivos têm focado principalmente em mega-eventos esportivos, tais como a Copa do Mundo e os Jogos Olímpicos. Contudo, recentemente, a comunidade acadêmica internacional tem direcionado um maior enfoque para os legados de eventos esportivos de menor porte, os quais têm sido chamados de "non-mega events" ou eventos não mega (TAKS, 2013).

O Brasil recentemente ganhou projeção internacional no cenário esportivo por sediar a Copa do Mundo de 2014 e os Jogos Olímpicos de 2016. Contudo, o país também tem sediado eventos esportivos internacionais e nacionais que podem ser classificados como eventos não mega. No contexto internacional, por exemplo, o país sediou os Jogos Mundiais Militares (2011) no Rio de Janeiro e os Jogos Mundiais dos Povos Indígenas (2015) em Palmas, Tocantins.

$\mathrm{O}$ interesse do presente projeto encontra-se em um evento genuinamente brasileiro com nuances muito específicas e culturalmente rico. Estas características estão ligadas a vários componentes, um deles tem a ver com o fato da sua constituição ser formada e estar envolvida com comunidades indígenas de todo o Brasil. Os JPI possuem características de um evento não mega, com nuances únicas quando comparado aos demais eventos desta natureza. Os JPI são uma idealização dos irmãos Carlos Justino Terena e Mariano Marcos Terena. Foram criados em 1996, como uma iniciativa indígena do Comitê Intertribal - Memória e Ciência Indígena (ITC), com o apoio do Ministério do Esporte do Brasil. As modalidades presentes nos JPI são divididas entre jogos tradicionais (por exemplo, a canoagem, arco e flecha, arremesso de lança, corrida de tora e cabo de força) e jogos ocidentais (como o futebol, o vôlei e a natação). Além destes jogos, estão presentes no evento apresentações culturais de dança, luta e rituais sagrados.

Atualmente, os JPI já estão na sua décima segunda edição. A última edição ocorreu em 2013 na cidade de Cuiabá em Mato Grosso, onde estiveram reunidos cerca de 1,6 mil representantes indígenas de 48 etnias brasileiras, entre homens e mulheres, jovens e idosos, além da presença de lideranças de povos indígenas de outros países, que vieram prestigiar o evento e participar do lançamento da $1^{\mathrm{a}}$ edição dos Jogos Mundiais dos Povos Indígenas. Os 
JPI brasileiros foram os precursores da primeira edição dos Jogos Mundiais dos Povos Indígenas (JMPI) ocorrida no ano de 2015 em Palmas-TO, onde estavam presentes 23 etnias brasileiras e delegações de 22 países. A segunda edição dos JMPI aconteceu no ano de 2017 Maskwascis província de Alberta, no Canadá, com a participação de mais de 2000 atletas de 30 países.

Considerando-se os grandes investimentos sociais e financeiros necessários para se organizar e sediar eventos, espera-se que estes deixem legados para diferentes grupos envolvidos no processo (ROCHA, 2017). Dentre estes grupos, podem estar a comunidade sede, os participantes, os espectadores, ou outros diretamente ou indiretamente envolvidos. Legados têm sido definidos como todas estruturas planejadas e não planejadas, positivas e negativas, intangíveis e tangíveis, que foram/serão criadas através de um evento esportivo e permanecerão após o evento (PREUSS, 2007). Neste intuito, o primeiro direcionamento do estudo foi compreender os aspectos da gestão esportiva e simultaneamente tomar como base a concepção diferenciada das práticas corporais de seus participantes, por meio da perspectiva do etno-desporto. Segundo Fassheber (2006), o etno-desporto indígena representa a possibilidade de transformações e adaptações das culturas indígenas. O entendimento da concepção diferenciada de corpo indígena com o suporte nos autores Mauss (2003) e Viveiro de Castro (1979) permitiu uma visão mais nítida sobre as práticas corporais que acontecem nos jogos. Além disso, esta compreensão permitiu um melhor enfretamento da análise sobre a abordagem da mídia com relação aos JPI.

Entender e classificar os JPI, com embasamento da gestão esportiva, considerando-o como um evento com características únicas, que demandam uma conceituação ampla no sentido de considerar as vivências, as práticas e culturas específicas destas comunidades proporciona uma melhor compreensão dos seus possíveis impactos e legados. A partir deste pressuposto, analisar como a mídia aborda os JPI pode apontar direcionamentos para o desenvolvimento de possíveis pesquisas que visem intervenções para alavancar legados e impactos destes tipos de evento.

Nesse sentido, o objetivo geral desta pesquisa é compreender como a mídia brasileira tem representado os Jogos dos Povos Indígenas (JPI). Os objetivos específicos são: analisar temas principais e secundários das reportagens, a incidência de reportagens relacionado à proximidade da cidade e número de povos indígenas naquela área, a visão do jornal sobre o conteúdo dos jogos, a descrição das etnias e modalidades, percepções positivas e negativas da mídia 
Em uma trajetória histórica, os eventos têm suas origens na antiguidade e desde os tempos mais primórdios, até os tempos modernos, têm como característica o envolvimento de várias pessoas nas diversas fases do seu planejamento e organização, além de atrair diversos tipos de participantes (POIT, 2006). Para este mesmo autor, os eventos apresentam-se como importante atividade econômica e social. Os Jogos Olímpicos da Era Antiga, datados de 776 a.C., podem ser considerados como a origem dos demais eventos esportivos.

Os Jogos Olímpicos tiveram a maior contribuição na organização de eventos esportivos, servindo de modelo para várias festas esportivas da época e padrão técnico e organizacional para a maioria dos eventos antigos e contemporâneos (POIT, 2006). Os eventos podem ainda ser definidos como:

[...] acontecimentos previamente planejados, com objetivos claramente definidos. Tem um perfil marcante: esportivo, social, cultural, filantrópico, religioso, entre outros. Sua realização obedece a um cronograma e uma de suas metas é a interação entre seus participantes, público, personalidades e entidades (POIT, 2006, p. 19).

No contexto esportivo, Santovito (2006) diz que:

Evento esportivo é uma competição de uma ou mais modalidades esportivas, destinada ao público consumidor desse esporte. Pode envolver ampla divulgação, organização, regulamentos específicos, homenagens a personalidades significativas de cada modalidade, cerimonial e protocolos oficiais de cada país, premiações diversas, interesse de empresas potenciais patrocinadoras, investimentos do poder público e parcerias relevantes da iniciativa privada (p. 3).

Segundo Poit (2006), pode-se dizer que a história nos fornece exemplos que incentivam a evolução dos eventos, talvez por uma necessidade humana de unir pessoas, comemorar vitórias, ou por outras necessidades. Ao se olhar por este prisma, é possível realizar uma ponte entre essas necessidades humanas e as expectativas do público dos eventos esportivos, tais como emoção, lazer, disputa e competição. Por outro lado, ou concomitante a este processo, o aumento dos eventos esportivos não se restringe apenas às necessidades do homem comum, mas também se vincula a interesses de empresários, administradores e políticos (TAVARES, 2011).

Neste contexto, a exemplo de grande expansão, destacam-se os megaeventos esportivos (MEE). O termo megaevento é recente em estudos acadêmicos e seu primeiro uso pode ser atribuído ao $37^{\circ}$ Congresso da Associação Internacional de Cientistas Especialistas 
em Calgary, em 1987, com o tema "O papel e o impacto dos megaeventos e atrações no desenvolvimento turístico regional e nacional" (MÜLLER, 2015). O surgimento do termo megaevento neste congresso e o fato dele ser considerado como uma atração turística pode explicar o foco em muitos estudos na área do turismo e do lazer (GETZ, 2008). Segundo Marris (1987), há três formas de definir os megaeventos: uma maneira é em volume, outra é por alguma medida de dinheiro e uma terceira via é em termos psicológicos:

\begin{abstract}
Uma definição de volume poderia estipular que, por exemplo, pelo menos um milhão de visitantes participa. Uma definição de valor pode ser o valor da receita para a localidade ou, como sugerido aqui, o custo de capital da construção de instalações. A terceira definição sugerida é psicológica, derivada dos sentimentos de turistas que vão ao evento ou atração. É tão importante que está em sua lista de coisas para visitar, então isso faz uma mega atração ou evento (Marris, 1987, p. 3).
\end{abstract}

Embora Müller (2015) considere que o número de ingressos vendidos seja a melhor variável de representatividade para atratividade de visitantes, para a qual os dados estão disponíveis em uma grande quantidade de eventos, ele ressalta que esta medida pode superestimar o número de visitantes únicos, pois alguns visitantes participam de várias competições. Outro ponto destacado pelo autor que apresentaria uma falha a esta medida, é o fato desses consumidores participarem sem a necessidade de estarem presentes no local, ou seja, assistirem na frente de uma tela. Isto significa dizer, que o telespectador tem a possibilidade de assistir ao evento, por exemplo, por meio da televisão, do computador ou pelo celular.

Müller (2015) propõe uma categorização heurística, onde é considerado que para um evento ser realmente "mega", ele deverá ser grande em quatro dimensões: um grande número de visitantes, grande alcance da mídia, grandes custos e grandes impactos no ambiente construído e na população. A exemplo desta classificação, Müller (2015) cita os Jogos Olímpicos (de verão) como evento giga. Como exemplo de megaeventos, Müller (2015) cita a Euro Copa de Futebol, a Copa do Mundo FIFA (masculina) e os Jogos Olímpicos de Inverno. Como exemplos de eventos principais (menores que mega, mas ainda com um apelo internacional), Müller (2015) cita os Jogos da Comunidade Britânica, as Universidades, os Jogos Panamericanos, a Copa do Mundo de Rugby e o "Super Bowl" de futebol americano. Müller (2015) propõe uma diferenciação de cada uma das quatro dimensões em três intervalos de tamanho, onde é estabelecido pontuações para cada tipo de evento. Portanto, para um evento ser um evento giga, segundo a classificação de Müller (2015), ele tem que alcançar 3 pontos em cada quatro das dimensões, com um total final de 11 a 12 pontos. O evento giga tem que ter mais de 3 milhões de tickets vendidos, o que equivale à dimensão do número de 
visitantes, ter o valor acima de 2 bilhões de dólares em direitos de transmissão, o que corresponde à dimensão do alcance da mídia, ter um custo maior que 10 bilhões de dólares, o que equivale à dimensão dos custos totais do evento e ter um capital de investimento maior que 10 bilhões de dólares, referente à dimensão dos impactos no ambiente construído e na população. Nesta mesma classificação, para o evento ser considerado um megaevento, ele tem que possuir 2 pontos em cada uma das quatro dimensões, com um total final de 7 a 10 pontos. O megaevento tem que ter mais de 1 milhão de tickets vendidos, ter o valor acima de 1 bilhão de dólares em direitos de transmissão, ter um custo de mais de 5 bilhões e um capital de investimento maior que 5 bilhões. Para ser considerado um evento principal, o evento deve alcançar 1 ponto em cada uma das quatro dimensões, com um total final de 1 a 6 pontos. Um evento principal deverá ter mais de 5 milhões de tickets vendidos, ter o valor acima de 1 bilhão de dólares em direitos de transmissão, ter um custo maior que 1 bilhão e um capital de investimento maior que 1 bilhão de dólares. Sendo assim, para o autor "megaeventos têm diferentes dimensões em que podem ser 'mega', mas nem todos os eventos são 'mega' nas mesmas dimensões e no mesmo grau. Portanto, não se deve perguntar se um evento é mega, mas como ele é. Para uma melhor visualização, segue abaixo a tabela de pontuação para classes de eventos de acordo com o tamanho, criada por Müller (2015, p. 9).

Em uma abordagem menos abrangente, Roche (2000) diferencia os eventos de acordo com seu tipo e dimensão, ao tentar classificar os eventos através de seu alcance de mídia e mercado. Embora Roche (2000) não apresente um estudo mais sistemático sobre os megaeventos, como realizado por Müller (2015), amplas explorações sócio históricas e relatos do fenômeno do megaevento na modernidade são mostrados. Roche (2000) realiza uma reflexão sobre os principais significados pessoais e interpessoais sobre os megaeventos, bem como alguns dos principais elementos do papel sociológico desempenhado pelos megaeventos no desenvolvimento da sociedade mundial. $\mathrm{O}$ autor ressalta ainda o aumento da popularidade dos megaeventos no século XXI, relacionando-o com a possibilidade dos megaeventos possuírem o papel de fornecer "alguns recursos e oportunidades culturais significativos para as pessoas da sociedade moderna abordarem as suas necessidades humanas básicas para os indivíduos (e também grupo) identidade...” (ROCHE, 2000, p. 218).

Horne $(2007$, p. 1) relata que as características centrais pelos quais os megaeventos são vistos "são consideradas como tendo consequências significativas para a cidade, região ou nação anfitriã em que ocorrem e, em segundo lugar, atrairão uma cobertura considerável da mídia”. Embora a caracterização de Horne (2007) seja classificada por Müller (2015) como sendo baseada apenas no alcance da mídia e no impacto transformador, ela faz uma reflexão 
sobre a necessidade de um olhar mais crítico sobre os efeitos econômicos e também para além dos efeitos econômicos que os megaeventos têm. Horne e Manzenreiter (2006) sugerem uma análise mais crítica sobre os pressupostos, crenças e desentendimentos que muitas vezes são reprimidos quanto à abordagem sobre megaeventos.

Horne (2007) parece concordar com Roche (2000), ao relatar que o desenvolvimento nas tecnologias da comunicação de massa, especialmente o desenvolvimento da televisão por satélite, criaram públicos internacionais sem precedentes para eventos como os Jogos Olímpicos e a Copa do Mundo. Ambos ressaltam que o atrativo estratégico para patrocinadores corporativos está diretamente relacionado ao tamanho do público da televisão. Horne (2007) questiona quem realmente se beneficia com os megaeventos, em que de um lado está "a redistribuição social" e do outro estão os interesses corporativos capitalistas. Esta abordagem é imprescindível para desmistificar a qualidade sedutora dos megaeventos e conduzir nossa visão por um prisma mais crítico, em que Horne (2007) afirma que os megaeventos são uma parte importante da experiência da modernidade, mas que é necessário manter uma posição independente para avaliar esses eventos.

A maioria dos eventos esportivos que acontecem não pode ser classificada como mega. Nesta direção, outros autores têm investigado organização, impactos e legados de eventos esportivos que eles chamam de "não-mega" - EENM (AGHA; TAKS, 2015; TAKS; CHALIP; GREEN, 2015). Estes eventos sempre existiram e recebiam outras denominações como eventos de médio porte, evento de pequeno porte, ou eram caracterizados de acordo com a sua abordagem geográfica (eventos locais, eventos estaduais, eventos nacionais, etc.). A denominação de um evento como não mega parece funcionar para diferenciá-los dos MEE, que captam a maior parte da atenção, principalmente da mídia.

Em uma reflexão sobre impactos sociais, Taks (2013) diferencia megaeventos de eventos não mega, onde em uma dimensão menor, os eventos não mega também atraem a atenção e o patrocínio da mídia em todos os níveis, e em relação ao número de participantes, a diferença consiste mais no tipo de participantes que os eventos não mega atendem do que na quantidade, que no caso dos megaeventos é maior. No que diz respeito à relação de poder, os eventos não mega parecem oportunizar uma maior participação da comunidade local na criação e no desenvolvimento do evento. Referente à regeneração urbana, Taks (2013) diz que os eventos não mega, embora em alguns casos possam necessitar de adaptações nas instalações esportivas, geralmente não requerem grandes projetos de infraestrutura urbana. Concernente ao capital humano, Taks (2013) expõe que as chances de desenvolvimento para residentes locais são maiores no contexto de eventos não mega. 
Em uma perspectiva diferente, Gibson, Kaplanidou e Kang (2012) investigam os eventos não mega, no contexto da sustentabilidade econômica, ambiental e social, por meio do turismo de esporte. Eventos de média escala é outro termo usado para definir eventos não mega. A distinção de megaeventos e eventos não mega segundo Gibson, Kaplanidou e Kang (2012) consiste nas mudanças ecológicas provocadas pela atividade turística e pelo desenvolvimento de infraestrutura, que no caso de eventos não mega, geralmente não necessitam de mudanças na infraestrutura utilizando as estruturas existentes. Desta forma, estes eventos teriam um saldo ecológico mais positivo, ao contrário da realização de megaeventos, que necessariamente precisam da construção de novas estruturas. O estudo conclui que embora este modelo de turismo sustentável possa não funcionar para todos os tipos de comunidade, pode funcionar para seus pilares econômicos, sociais e ambientais.

Sob uma ótica econômica houve o desenvolvimento de uma tipologia para analisar o impacto significativo dos principais eventos esportivos (GRATTON; DOBSON; SHIBLI, 2000). A tipologia consiste em seis divisões: o tipo A que são eventos de espectadores internacionais irregulares, únicos e importantes, gerando atividade econômica significativa e interesse na mídia (por exemplo, Jogos Olímpicos, Copa do Mundo de Futebol, Campeonato Europeu de Futebol); o tipo B que são os principais eventos de espectadores, gerando atividade econômica significativa, interesse da mídia e parte de um ciclo doméstico anual de eventos esportivos (por exemplo, final da Copa de Futebol da Inglaterra a FA Cup, o torneio "Six Nations Rugby Union International”, o torneio Open de golfe da Associação Profissional de Golfe (PGA), e o torneio de tênis em Wimbledon); o tipo C que consiste eventos regulares, únicos, principais eventos internacionais de espectadores / concorrentes que geram atividade econômica limitada (por exemplo, Campeonato Europeu de Boxe Júnior, Campeonato Europeu de Natação Júnior, Campeonato Mundial de Badminton, Grande Prêmio da Associação Internacional das Federações de Atletismo); e o tipo D que são os principais eventos de concorrentes gerando atividade econômica limitada e parte de um ciclo anual de eventos esportivos (por exemplo, Campeonatos Nacionais na maioria dos esportes). Embora este estudo tenha características exclusivamente econômicas, ele apresenta uma ferramenta importante na compreensão dos eventos esportivos e mostra "uma grande variação entre os eventos esportivos em sua capacidade de gerar impacto econômico na cidade anfitriã" (GRATTON; DOBSON; SHIBLI, 2000, p. 27).

Com o objetivo contrário à divagação em conceitos ou definições rigorosas, esse caminho inicial é importante para se entender um pouco da dimensão dos megaeventos e dos eventos não mega, pois são acontecimentos distintos que podem ser vistos por muitos 
prismas. Em geral, estes prismas variam de acordo com a avaliação dos impactos dos eventos, os quais têm focado em aspectos diversos, tais como o econômico, o turístico, o social ou o da participação no esporte (AGHA; TAKS, 2015). Uma conceituação mais acadêmica acerca dos eventos esportivos é importante para se evitar o senso comum, onde genericamente o termo megaevento é empregado como sinônimo de grandes competições. Referente aos conceitos de megaeventos e eventos não mega, Tavares (2011) relata que alguns autores já consideram a distinção entre estes como entendimento tácito, que dispensaria definições mais rigorosas. Porém, tais definições não são tão simples assim. É necessário estabelecer claramente os limites que separam os megaeventos dos demais, principalmente porque os impactos que os eventos têm em suas comunidades e economias variam de acordo com o tamanho e apelo da mídia do mesmo (TAKS; CHALIP; GREEN, 2015).

A questão dos impactos e dos legados tem recebido substancial atenção por parte de organizadores e da classe acadêmica. Esse direcionamento dos autores aos impactos e legados dos eventos esportivos são tão importantes quanto o entendimento de suas definições. Vários autores têm abordado a questão dos impactos e dos legados em função da característica do evento (megaevento vs. evento não mega). Contudo, a literatura tem sido consistente ao considerar a natureza multidimensional dos impactos e dos legados, os quais têm sido abordados sem seus aspectos econômicos, sociais, ambientais e/ou culturais (HORNE; MANZENREITER, 2006; TAKS, 2013; MÜLLER, 2015; AGHA; TAKS, 2015; TAKS; CHALIP; GREEN, 2015). A seguir, os principais legados dos megaeventos e os eventos não mega serão discutidos.

Etimologicamente o significado da palavra legado não representa o contexto em que é usado na literatura de eventos. Para Preuss (2007), uma definição geral de legado deve ser independente de exemplos qualitativos. Preuss (2007) propõe que legado são todas as estruturas planejadas e não planejadas, positivas e negativas, intangíveis e tangíveis, que foram/serão criadas através de um evento esportivo e permanecerão após o evento. Para Preuss (2007) o significado de legados de eventos esportivos na literatura não é satisfatório, pois ao contrário do que é exposto, o legado de eventos esportivos não pertence a alguém, como os organizadores dos eventos ou entidades políticas, mas é considerado um bem público. Os eventos também causam legados que não são planejados, como externalidades positivas e/ou negativas. No âmbito dos megaeventos, as externalidades podem ser entendidas 
como os efeitos das decisões sobre aqueles indivíduos que não participam diretamente delas, ou seja, é uma atividade que envolve a imposição involuntária de custos ou benefícios. A construção da Vila Olímpica em Barcelona pode ser entendida como uma externalidade negativa, pois segundo Bronstein (2012), houve uma grande valorização da área residencial, após a construção da vila, o que inviabilizou o objetivo inicial do projeto que era fornecer abrigo à população de classe média. Porém, em um outro aspecto, na perspectiva de Roche (2000), apesar dos debates locais sobre um processo de gentrificação ligados à construção da Vila Olímpica, o mesmo evento pode ser considerado como exemplo de uma externalidade positiva por ter se tornado um polo turístico de grande importância para a cidade.

Ainda sobre legados, Preuss (2007) diz que para sua mensuração devem ser considerados como resultados de eventos únicos que envolvem diversas áreas como as sociais, as econômicas, que fazem parte de um processo dinâmico e sofrem variações quando realizado em diferentes cidades, eventos e horários. Nesse contexto, Preuss (2007) relata que o mesmo evento ocorrido na mesma cidade gera legados diferentes, pois o evento e o mundo sofrem mudanças. Diferentes eventos ocorridos na mesma cidade também podem gerar legados diferentes, embora em alguns casos os legados possam ser os mesmos. Concernente à construção de legados em eventos esportivos, "a estratégia se concentra nas estruturas adicionais criadas por um evento e na necessidade de longo prazo dessas estruturas" (PREUSS, 2007, p. 7).

Historicamente pode-se dizer que o planejamento de legados teve seu início em 2002, quando o Comitê Olímpico Internacional (COI) sofreu uma série de críticas devido aos prejuízos causados às cidades anfitriãs dos eventos esportivos (SOUZA; PAPOUS, 2013). Com a participação de mais de 150 experts na comunidade internacional sobre Jogos Olímpicos, elaborou-se um documento que relata as necessidades de planejamento dos legados, no qual o COI começou a enquadrar o conceito de legado juntamente com o conceito de desenvolvimento sustentável do esporte. Assim, legado tornou-se parte essencial do vocabulário do COI e dos Comitês Organizadores dos Jogos Olímpicos (COJOs) (GIRGINOV; HILLS, 2008). Os COJOs são criados pelo Comitê Nacional Olímpico (CON) e juntamente com a cidade anfitriã, segundo a Carta Olímpica, são conjunta e solidariamente responsáveis por todos os compromissos contraídos individual ou coletivamente em relação à organização e ao desenrolar dos Jogos Olímpicos, salvo no que concerne à responsabilidade financeira da organização e do desenrolar dos Jogos, que será inteiramente assumida conjunta e solidariamente pela cidade anfitriã e pelo COJO.

Contudo, até recentemente no plano internacional, os estudos de megaeventos e 
legados tinham suas bases assentadas nos chamados Estudos Olímpicos (EO), que são:

[...] uma área, de teorias e práticas desenvolvidas em universidades e entidades afins como centros de informação, museus de esporte, etc., voltada para os Jogos Olímpicos, o Movimento Olímpico e o Olimpismo. Esta especialização foi proposta pelo Barão Coubertin nos anos de 1930, antes de seu falecimento, e posteriormente foi promovida pela Academia Olímpica Internacional - IOA, sediada em Olímpia, Grécia, e por suas entidades filiadas, as Academias Olímpicas Nacionais vinculadas aos Comitês Olímpicos Nacionais.[...] (Da COSTA; MIRAGAYA, 2008, p. 33-46).

Em relação aos legados dos eventos esportivos podemos destacar também, como um dos estudos pioneiros, as dimensões propostas por Brent Ritchie (1984), são elas: econômicas, turismo/comercial, físico, sociocultural, psicológica e política.

As pesquisas decorrentes parecem derivar destas dimensões, concentrando-se na maior parte na área turística e econômica (TAKS, 2013). Podemos destacar, ainda, um redirecionamento nas pesquisas sobre impactos menos tangíveis, como os sociais e de participação no esporte, com os megaeventos como protagonistas (TAKS, 2013). Na abordagem de impactos sociais, sobre as diferenças de megaeventos e eventos não mega, Taks (2013, p. 124) afirma que ambos os eventos podem gerar "impactos sociais de curto ou longo prazo, positivos ou negativos, que podem levar a resultados sociais positivos ou negativos". Para o autor, esses resultados podem tornar-se legados se perdurarem, ou seja, se eles forem sustentados. Nesta perspectiva parece ser importante observar os impactos desses eventos como possibilidade de futuros legados. Os impactos são tangíveis e, embora tenham grande expressividade em megaeventos, eles diferem dos legados pois os impactos possuem uma curta duração e a sua medição, devido ao seu aspecto tangível, é usada como uma justificativa política para investimentos de recursos escassos em eventos deste porte. Segundo Preuss (2007), a movimentação econômica gerada pelos visitantes do megaevento é considerada como um impacto econômico pois eles são de curto prazo. Porém, se as melhorias nas estruturas da cidade anfitriã atraíssem um número fixo de turistas que gerassem um influxo de capital a longo prazo esta atividade seria considerada um legado econômico.

O conceito de legado no contexto de megaeventos é complexo. Os legados de megaeventos têm a sua construção baseada na multidimensionalidade positiva, no qual as suas dimensões estariam de alguma forma correlacionadas entre si (ROCHA; BARBANTI; CHELLADURAI, 2016). Segundo Rocha, Barbanti e Chelladurai (2016), essa característica multidimensional positiva tem sido utilizada para promover o apoio popular aos megaeventos.

Neste sentido, com base na teoria da troca social, Rocha, Barbanti e Chelladurai 
(2016), relacionaram as expectativas de legados multidimensionais positivos e o trabalho do governo na preparação ao receber o evento com o apoio dos residentes locais às Olimpíadas de 2016 no Rio de Janeiro. O estudo constatou que quanto mais os residentes do Rio de Janeiro acreditavam nos benefícios multidimensionais advindos do evento mais eles estavam dispostos a apoiar o evento.

A outra relação foi entre uma melhor percepção do trabalho do governo e uma maior intenção dos residentes em apoiar o evento. No entanto, a intenção em apoiar o evento foi menor em pessoas com baixo poder aquisitivo, pois segundo Rocha, Barbanti e Chelladurai (2016) talvez os cidadãos de baixa renda do Rio de Janeiro tenham a consciência que não vão ter benefícios advindos dos Jogos como os cidadãos de alta renda. Um outro fator importante a se destacar sobre as maiores expectativas dos residentes em relação ao legado de turismo quando comparado as expectativas do legado ambiental. De acordo com Rocha, Barbanti e Chelladurai (2016) a baixa expectativa com relação aos legados ambientais, pode ser decorrente dos problemas ambientais ocorridos em edições anteriores e a falta de legados positive nestas edições. Outro fator está ligado aos impactos ambientais ocorridos no Rio de Janeiro durante a preparação dos eventos. Como exemplo, os autores citam a construção de um campo de golfe nas Olimpíadas de 2016 no Rio de Janeiro, construída em área de preservação ambiental, no qual teoricamente nada poderia ser construído.

Em uma abordagem econômica, Agha e Taks (2015) criaram uma estrutura que considera as características do evento e da cidade, enfatizando a importância dos requisitos de recursos, físicos, financeiros e humanos. O estudo apresenta o conceito de Demanda de Recursos de Eventos (DRE) como uma medida multivariada dos recursos totais necessários para organizar um evento. Em relação às cidades, é apresentado o conceito de Fonte de Recursos da Cidade (FRC) como uma medida multivariada dos recursos totais que uma cidade fornece para organizar o evento (locais, voluntários, funcionários, etc.). Segundo Agha e Taks (2015) o tamanho do evento é determinado pelos recursos locais necessários. Os recursos humanos, financeiros e físicos são representados respectivamente por funcionários e voluntários, investimentos privados e governamentais, alojamento, transporte público e privado e serviços de alimentação. Por meio desta abordagem os autores concluíram que há um nível igual de benefícios para pequenos eventos em cidades pequenas e grandes, mas custos são geralmente mais altos para pequenos eventos nas pequenas cidades do que nas grandes cidades.

Outro ponto a destacar da pesquisa de Agha e Taks (2015), é que segundo eles, quanto maior a deficiência de recursos, maior a redução do impacto econômico indicando que 
eventos menores com uma menor demanda de recursos têm maior potencial de impacto econômico ótimo em comparação com eventos maiores com maiores demandas de recursos. Em suma, parece que mesmo no caso de pequenos eventos em que o FRC seja menor que o DRE, esses eventos estão mais próximos de alcançar o impacto econômico ótimo que os grandes eventos.

Porém, para Taks, Chalip e Green (2015), por meio dessa ótica, parece ser óbvio que os eventos de menor escala exijam menos recursos e, portanto, sejam mais propensos a gerar resultados econômicos mais positivos (ou menos negativos) do que os megaeventos esportivos. Contudo, em relação aos eventos não mega, os autores parecem concordar com o fato que esses eventos proporcionam oportunidades para impactos e resultados sociais mais positivos (ou menos negativos) para comunidades anfitriãs do que os megaeventos esportivos. A probabilidade maior da ocorrência de impactos sociais mais positivos em eventos não mega ocorreria devido à maior reciprocidade nas comunidades anfitriãs. Segundo Taks, Chalip e Green (2015), o voluntariado em eventos não mega é uma experiência coletiva e um resultado direto do capital social, o que parece gerar um maior capital humano nas comunidades anfitriãs. Outro fator importante no que tange capital social, é o legado de participação, que pode ser gerado pelo impacto de participação. Taks, Chalip e Green (2015) relatam que as infraestruturas nos eventos não mega geralmente são atualizadas ou construídas visando a comunidade anfitriã, o que pode proporcionar a utilização destes espaços a longo prazo para a participação no esporte de uma forma mais sustentável.

A expressão capital social utilizada por Taks, Chalip e Green (2015), pode ser entendida como sinônimo de legado de participação, contudo segundo Portes (2000), o alargamento deste conceito pode colocar seu valor heurístico em risco. Portes (2000) diz que dentre as teorias sociológicas o capital social foi uma das mais utilizadas e usadas em diferentes contextos. De acordo com Portes (2000, p. 153) para a abordagem sobre o capital social é necessário reconhecer “... suas diferentes fontes e os seus diferentes efeitos, e que os seus aspectos negativos sejam examinados com a mesma atenção." Neste mesmo direcionamento D'Araújo (2003) diz que o conceito de capital social quando mal compreendido pode desqualificá-lo como instrumento conceitual e prático para a consolidação de políticas públicas. Segundo D’Araújo (2003, p. 10) capital social tem haver com a capacidade de cooperação e confiança para a produção do bem público, no qual a autora o define como “... a argamassa que mantém as instituições em contato entre si e as vincula ao cidadão visando à produção do bem comum."

No que tange o estudo sobre o legado de participação, os resultados mostram-se 
contraditórios, pois segundo Wicker e Sotiriadou (2013) os resultados apresentados na literatura são em geral resultados intangíveis e controversos. Nessa acepção, um dos efeitos abordados na literatura acadêmica referentes ao legado de participação em megaeventos é o "trickle-down effect", expressão em inglês que seria equivalente ao "efeito cascata". O "trickle-down effect" é um efeito que inspira os indivíduos a participar mais de atividades físicas e esporte através da inspiração gerada pelo esporte de elite em grandes eventos (WICKER; SOTIRIADOU, 2013).

Nesse sentido, é possível observar uma grande parte da literatura de megaeventos que aborda a participação esportiva (WEED et al., 2009; POTWARKA; LEATHERDALE, 2016; CHALIP et al., 2017). Em relação aos Jogos Olímpicos, a maioria dos estudos apresenta evidências inconclusivas, mas que dizem que o esporte de alto rendimento parece ter um resultado contrário à inspiração da participação, devido à diferença de competência percebida (WEED et al., 2009). Contudo, Reis, de Sousa-Mast e Gurgel (2013) ressaltam a necessidade de planejamento para alavancar os legados de participação dos eventos principais, os eventos esportivos necessitam ser melhor planejados, para que tenham maior possibilidade de gerar legados de participação, pois apenas a sua realização não é garantia “[...] para aumentar a participação em atividades físicas e esportivas, ou para incentivar comportamentos saudáveis de saúde" (WEED et al., 2009, p. 57). Porém, de acordo Wicker e Sotiriadou (2013), é importante analisar o "trickle-down effect" em grupos específicos, pois seria possível identificar os grupos que se beneficiariam mais do que outros e por quais motivos.

Sob o mesmo ponto de vista de Wicker e Sotiriadou (2013), Potwarka e Leatherdale (2016) relatam a importância de se investigar o efeito cascata em segmentos particulares de uma população e sobre a necessidade desta investigação ocorrer com comunidades próximas ao evento. Para Potwarka e Leatherdale (2016, p. 243), em direção ao que relata Weed et al. (2009) a deficiência na literatura acadêmica sobre o "trickle-down effect" decorre da falta de dados apropriados. Isso ocorreria, na opinião destes autores, devido ao fato de os estudos serem realizados a nível macro, abrangendo toda a nação, estado ou província, pois as pesquisas “[...] devem considerar dados de participação mais localizados entre subpopulações particulares dos anfitriões do evento". Potwarka e Leatherdale (2016) utilizaram dados do Canadian Institute for Health Information para analisar os possíveis níveis de participação de jovens de ambos os sexos gerados pelas Olimpíadas de Inverno de Vancouver 2010, onde foi observado um aumento significativo na taxa de mulheres ativas/moderadamente ativas de 2007-2008 (pré-evento) para 2009-2010 (ano anterior ao evento e ano em que o evento foi encenado). Outro dado importante desta pesquisa, foi o fato da mudança em relação ao 
aumento da participação ser sustentado por pelo menos dois anos. Embora tal estudo ainda não seja suficiente para fornecer dados definitivos sobre o "trickle-down effect", pela falta de dados longitudinais, a pesquisa é uma das pioneiras a encontrar níveis de atividade física e de lazer que podem ser atribuídos a um megaevento.

O legado de participação é uma constante nos discursos das autoridades ao se tentar promover os megaeventos. Contudo, se o "trickle-down effect" for uma realidade, seja em comunidades e grupos específicos mais próximos à realização do evento, como defende Potwarka e Leatherdale (2016) ou se o "trickle-down effect" proporcionar um resultado contrário à motivação para a população tornar-se mais ativa como relata Weed et al. (2009), o aumento da participação da população no esporte a partir de eventos esportivos necessita ser planejado. $\mathrm{O}$ método de debate e construção de ideias para a alavancagem da participação esportiva a partir dos megaeventos proposto por Chalip et al. (2017), parece ser uma boa alternativa. O estudo desenvolvido por Chalip et al. (2017) formou um grupo de especialistas que estavam envolvidos e/ou se beneficiariam do evento para identificar os desafios e propor alternativas no processo de alavancagem da participação. Um dos maiores desafios encontrados foi o contraste entre as habilidades dos atletas e a percepção da população em relação às suas próprias habilidades (CHALIP et al., 2017). Como alternativa para este desafio, o grupo de especialistas sugeriu que um sentimento de conexão fosse desenvolvido a partir da construção de uma imagem mais realista ou humana dos atletas por meio do apoio da mídia (CHALIP et al. 2017). Contudo, a alavancagem da participação necessita da aliança entre as organizações esportivas e os organizadores do evento.

O capital social parece ser um dos legados mais importantes dos eventos esportivos. Este tem sido estudado na literatura acadêmica em concepções referentes às questões civis, bem-estar, identidades coletivas, regeneração urbana, capital humano e participação no esporte (DJABALLAH; DESBORDES; HAUTBOIS, 2015). Segunto Taks (2013) os eventos não mega tendem a gerar um capital social mais horizontal em relação aos megaeventos, ou seja, uma forma de capital social que representa igualdade entre os cidadãos, no qual ocorreira uma maior participação cívica e o um aumento no nível de confiança social.

A pesquisa de Ruhanen e Whitford (2011) sobre o Festival Esportivo e Cultural Anual que ocorre na cidade de Brisbane, na Austrália, reafirma a premissa que eventos não mega tendem a gerar um capital social mais positivo, principalmente referente ao legado de participação. Este festival é um evento esportivo indígena, com comunidades em torno da Austrália e do Pacífico Sul, que ocorre anualmente desde 1993. Segundo Ruhanen e Whitford (2011), os aborígenes australianos mesmo já possuindo um histórico de atividades esportivas 
e de lazer anterior ao evento, possuem benefícios mais amplos, como exemplo a experiência canadense de comunidades francófonas minoritárias demonstra o sucesso da promoção de identidades indígenas através da organização de eventos esportivos. De acordo com Ruhanen e Whitford (2011, p. 43), o Festival Esportivo e Cultural Anual proporcionou "uma ocasião para se envolver em atividades esportivas e de lazer, uma oportunidade de compartilhar e fortalecer a cultura e a identidade da comunidade, e o desenvolvimento do capital social".

Nesse contexto, no qual os eventos não mega tem um maior potencial para o desenvolvimento de capital social, os Jogos dos Povos Indígenas (JPI) podem e devem ser entendidos com uma relevante oportunidade para as comunidades indígenas brasileiras. Classificar os JPI no meio científico significa sair do campo de definições do senso comum e possibilitar a construção de conceitos mais sólidos.

Como afirma Gruppi (2013, p. 85), “os Jogos dos Povos Indígenas são ações idealizadas pelos irmãos Mariano Marcos Terena e Carlos Justino Terena por meio do Comitê Intertribal de Memória e Ciência Indígena em parceria com o Ministério do Esporte [...]”. De acordo com dados do Ministério do Esporte (http://www.esporte.gov.br/), a primeira edição dos Jogos dos Povos Indígenas ocorreu em 1996 em Goiânia, com a participação de mais de 30 etnias. Os jogos têm sido organizados pelo Comitê Intertribal Memória e Ciência Indígena (ITC) e patrocinados pelo Ministério do Esporte. Os jogos estão na sua XIII edição, que ocorreu em 2013 na cidade de Cuiabá, no qual estiveram presentes 48 etnias. Algumas das modalidades presentes nos jogos são: canoagem, arco e flecha, arremesso de lança, corrida de tora, cabo de força e futebol. O principal lema dos jogos é “celebrar e não competir”, seja nas atividades tradicionais ou não tradicionais, assim relatada por Gruppi (2013, p. 110):

\footnotetext{
As práticas corporais consideradas pelos indígenas como tradicionais são as que fazem parte de seus rituais, e as práticas ocidentais como o futebol compõem os Jogos dos Povos Indígenas e revelam as manifestações culturais desses povos, com intenção de celebrar o encontro das etnias sem se preocuparem com resultados ou performances.
}

De acordo com Gruppi (2013), os Jogos dos Povos Indígenas ao longo das edições de 1996 a 2011 tiveram como organizadores os seus idealizadores representantes do Comitê Intertribal Memória e Ciência Indígena, bem como o apoio de setores como os Ministérios da Educação, Cultura, Justiça, Esportes, e das Secretarias Estaduais e Municipais. As edições XI e a XII dos jogos também foram realizados com o apoio do Comitê Intertribal - Memória e 
Ciência Indígena (ITC), dos governos locais das cidades anfitriãs e com o patrocínio do Ministério do Esporte. Desde 2019 com a extinção do Minsitério do Esporte, a pasta do esporte foi incorporada ao Ministério da Cidadania, Ministério da Cultura e Ministério do Desenvolviemnto Social. Após estas mudanças, teoricamente, o apoio aos JPI estariam submetidos a estes ministérios, porém até o fechamento desta pesquisa nenhuma informação sobre realizações futuras dos JPI foram relatadas. Os JPI não possuem uma periodicidade regular, pois a sua realização está vinculada à diversos fatores, o mais determinante deles está veiculdao aos embates dos seus idealizadores e organizadores com as decisões da gestão federal vigente.

O lema dos jogos, acima colocado, nos remete à ideia da concepção diferenciada que os povos indígenas têm das práticas corporais e a importância de reconhecer as especificidades de cada etnia. Nessa visão, caracterizar o evento JPI como não mega nos remete a uma reflexão mais profunda, que abarcará o envolvimento de áreas tais como a sociologia e a antropologia. Contudo, o foco do presente trabalho ao classificar os JPI como não mega se encontra na possibilidade de verificar legados positivos que estes trazem para os principais beneficiários, os indígenas (RAMCHANDANI et al, 2015; AGHA; TAKS, 2015). Quanto aos possíveis legados no aspecto político, Pinto (2015, p. 38) relata que com a iniciativa dos irmãos Marcos e Carlos Terena foi possível abrir caminho para garantia de alguns direitos indígenas:

[...] consagrados pelos artigos 231 e 232 da Constituição federal brasileira de 1988. Direitos também legitimados pela Convenção n.169 da Organização Internacional do Trabalho (OIT), de 07/06/1989, homologada pelo Governo Brasileiro por meio do Decreto Presidencial 5.051, de 19 de abril de 2004; a Política Nacional de Esporte (Brasil, 2005); e a Declaração das Nações Unidas sobre os Direitos dos Povos Indígenas de 07/09/2007.

Outro legado importante atribuído aos JPI por Pinto (2015), é a revitalização da ludodiversidade cultural por meio da inclusão de modalidades tradicionais relacionadas à sobrevivência e rituais sagrados. O legado da valorização da visão de mundo indígena, da sua espiritualidade e de suas memórias está apoiado por meio do uso nos JPI de símbolos da natureza como a água, o fogo e as sementes. A escolha dos temas e das logos, onde sempre estão presentes aspectos da cultura indígena, também reforçam este legado (PINTO, 2015).

Em entrevista concedida para Pinto (2015), Marcos Terena, diz que os JPI têm como um dos seus objetivos conscientizarem a população que o evento não se trata apenas de um campeonato de índios, de esportes indígenas, mas que os Jogos têm toda uma celebração, uma 
tradição, um rito que se faz na aldeia e que precisava ser trazido para a cidade. Ainda, para Pinto (2015), os JPI são festas que têm por objetivo celebrar vidas humanas e sua relação com a natureza: terra e meio ambiente. Dentro desta perspectiva, pode-se dizer que esses eventos têm características singulares, ilustrado, por exemplo, pela escolha dos temas, como relatado acima, em cada edição, como explana Pinto (2015, p. 48):

I JPI: Goiânia/GO, 1996: Programa do Índio - Os povos indígenas vão mostrar que esporte não é reserva de branco. II JPI: Guaíra/PR, 1999 (na fronteira ArgentinaParaguai): A Terra de todas as Tribos. III JPI: Marabá/PA, 2000 (na Amazônia brasileira): A União das Tribos. IV JPI: Campo Grande/MS, 2001 (região do Pantanal): Compromisso com nossas Tribos. V JPI: Marapanim/PA, 2002: Jogos do Homem-Natureza. VI JPI: Palmas/TO, 2003: Esta Terra é Nossa. VII JPI: Porto Seguro/BA, 2004 (local da chegada dos "caraíbas" portugueses): 1994/2004 Década Internacional do Índio. VIII JPI: Fortaleza/CE, 2005: O importante não é competir e, sim, celebrar. IX JPI: Recife e Olinda/PE, 2007: Água é vida, direito sagrado que não se vende. X JPI: Paragominas/PA, 2009: O importante não é ganhar e, sim, celebrar. XI JPI: Porto Nacional/TO, 2011: Importante não é ganhar e, sim, celebrar. XII JPI: Cuiabá/MT, 2013: Soberania alimentar: alimentação e respeito à Mãe Terra (Fontes: Site do ITC; banco de dados LABJOR/Unicamp).

Abaixo os logos compilados por Ferreira e Vinha (2015, p. 48).

Figura 1 - Logos da I a X edições dos JPI

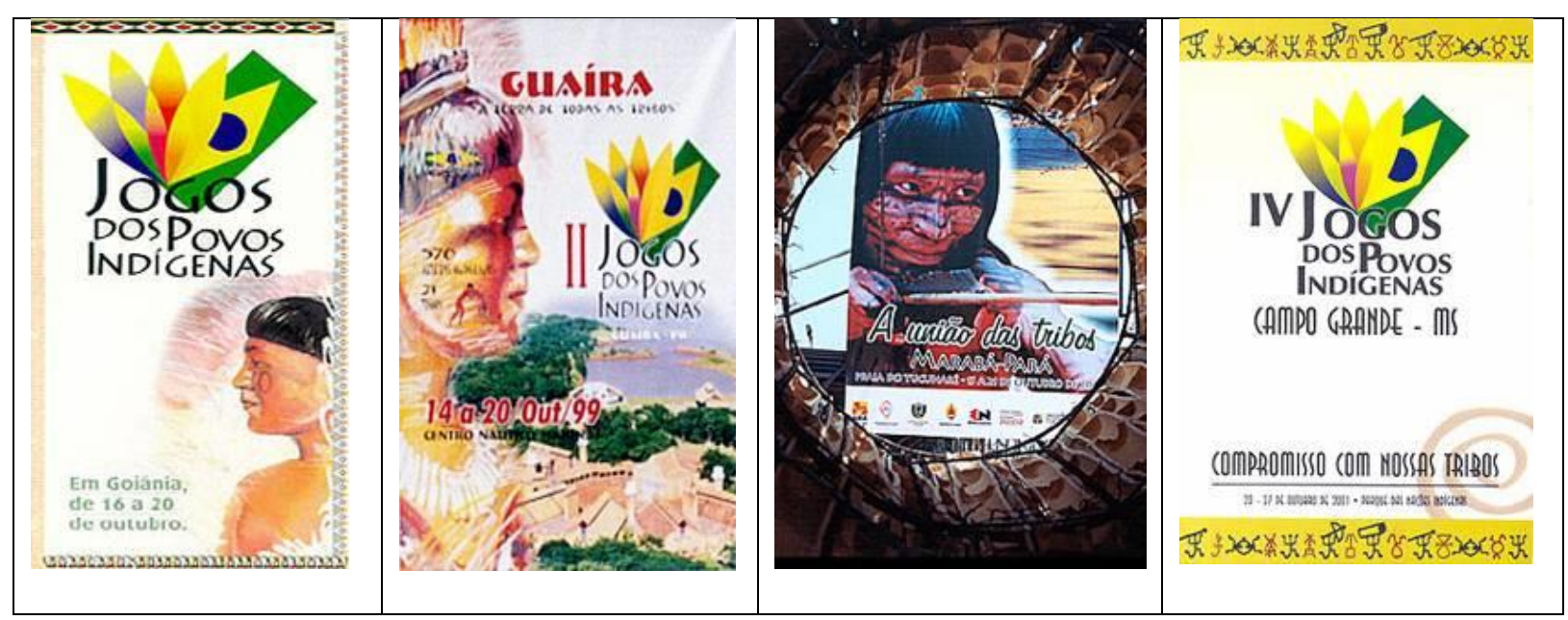




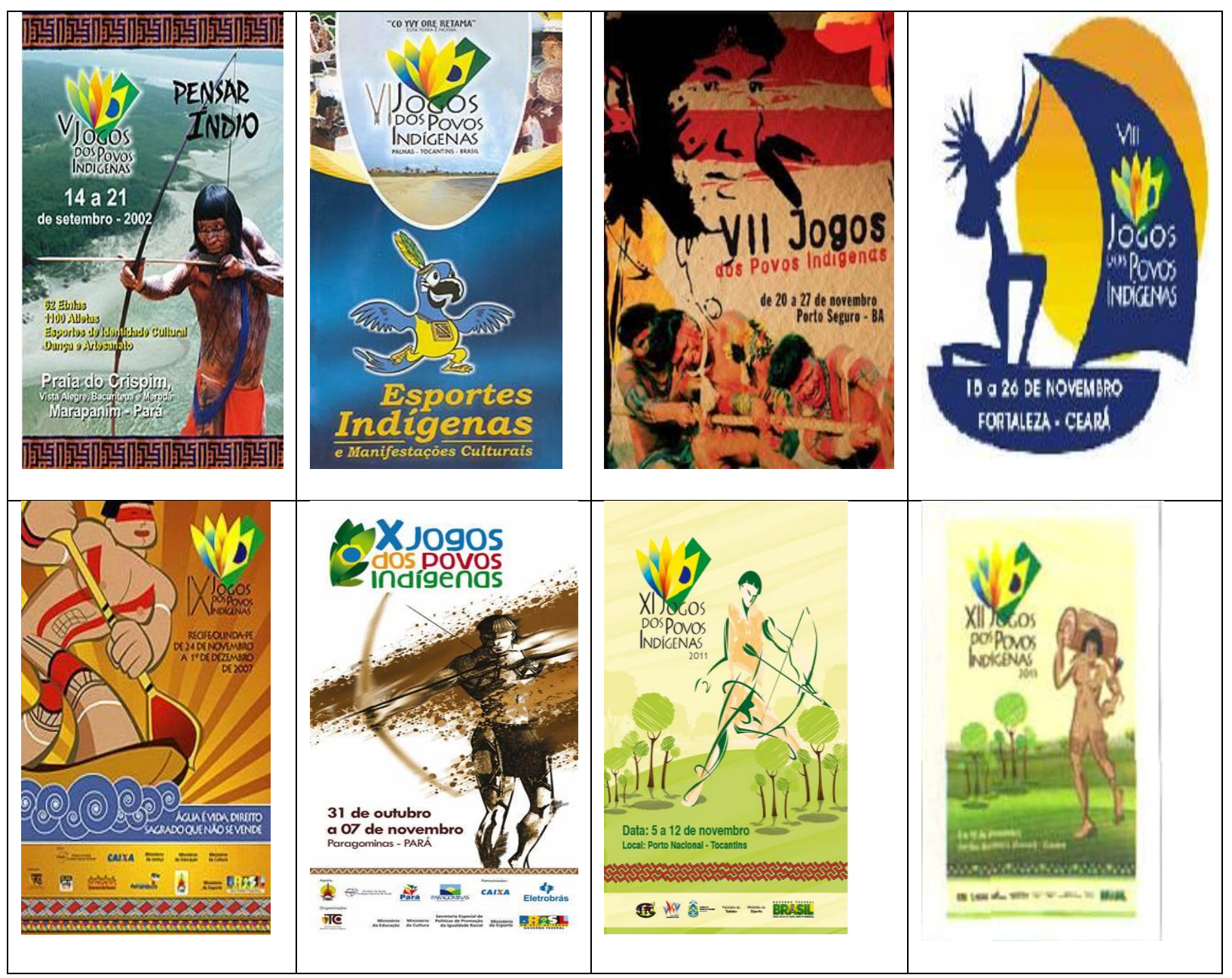

Segundo Almeida (2008), os Jogos nasceram de uma demanda dos povos indígenas brasileiros aos órgãos governamentais e, de acordo com o Regulamento Geral, têm por finalidade fortalecer a identidade cultural das sociedades indígenas, procurando obedecer à concepção e à filosofia tradicional de cada etnia participante. Contudo, os JPI são um evento esportivo amparado por lei, previsto na Constituição Federal Brasileira de 1988, no Artigo 217, que diz que é dever do Estado fomentar práticas esportivas formais e não-formais, como direito de cada um especialmente o inciso IV que trata sobre a proteção e o incentivo às manifestações esportivas de criação nacional.

Além desse artigo, os JPI são uma via para garantir também os direitos previstos nos artigos 231 e 232 da Constituição Federal Brasileira que tratam sobre garantias à cultura e o direito às terras dos índios. A Declaração da ONU (Organização das Nações Unidas) dos Direitos dos Povos Indígenas reconhece e afirma direitos fundamentais e universais no contexto das culturas, realidades e necessidades indígenas. No momento denominado como “Década Internacional do Índio" a primeira edição dos JPI ocorrida em Goiânia (1996) foi considerada como o evento mais importante realizado em nível nacional e internacional 
(GRUPPI, 2013). O pioneirismo brasileiro em reafirmar e promover os direitos dos povos indígenas por meio da promoção dos JPI vem ao encontro com os propósitos e princípios da Declaração das Nações Unidas sobre os Direitos dos Povos Indígenas.

No quadro em que os indígenas brasileiros são um grupo em risco de exclusão social os JPI se apresentam como uma alternativa para conquista de legados nas áreas políticas; na revitalização da ludodiversidade cultural; na valorização da visão de mundo indígena, na sua espiritualidade e memórias; e nas trocas entre indígenas e destes com os não indígenas (PINTO, 2015, p. 39). Nessa linha de considerações, Harvey (2001) diz que a participação em eventos esportivos e de recreação tem benefícios positivos no desenvolvimento emocional, físico e social, especialmente em grupos com risco de exclusão social. A despeito disso, os JPI como evento não mega e com protagonismo indígena têm maiores probabilidades de legados positivos.

Sendo assim, o propósito de apresentar um breve histórico dos JPI e explanar sobre seus objetivos foi tentar construir uma base para caracterizá-lo como um evento não mega, com potencial de deixar legados para os seus principais beneficiários. A seguir uma amostra da situação indígena em que a perspectiva dos legados pode estar inserida.

O contato cultural da população indígena de todo mundo com pessoas não indígenas é formado por uma história de preconceito e discriminação, que afeta profundamente seu bemestar físico, social e psicológico. Segundo Trovato (2001), existe uma grande mortalidade nestas comunidades por morte prematura por acidentes, violência e suicídio, enquanto, ao mesmo tempo, nas últimas décadas houve uma crescente incidência de doenças crônicas degenerativas. De acordo com Cardoso, Mattos e Souza (2001), fatores que colaboram para essa baixa qualidade de vida estão ligados às mudanças alimentares, estresse psicológico, sedentarismo, obesidade, hereditariedade e mudanças socioeconômicas. O estudo realizado por Cardoso, Mattos e Koifman (2001) diz que em decorrência do processo de crise de identidade cultural, destruição dos ecossistemas, onde os indígenas vivem, e mudanças de hábito acarretaram um aumento das doenças de diabetes, cardiovasculares e transtornos mentais. Em relação à saúde mental, Oliveira e Lotufo Neto (2003) relatam que a maioria da população indígena apresenta problemas como depressão e abuso de substâncias químicas como a exemplo dos índios norte-americanos do sudoeste dos EUA, dos esquimós do oeste do Alaska e dos nativos do Canadá, principalmente os indígenas da etnia Cree. 
O estudo realizado por Ferreira, Matsuo e Souza (2011) mostra que a realidade da população indígena no Brasil não é diferente. As mudanças do seu estilo de vida, da sua relação com a terra, a incorporação de novos hábitos culturais e a diminuição das atividades físicas também acarretou um aumento em doenças crônico-degenerativas como diabetes mellitus, obesidade e hipertensão. A pesquisa realizada com indígenas do Mato Grosso do Sul, onde se concentra a segunda maior população indígena do país, mostrou a existência de doenças cardiovasculares atribuídas principalmente às alterações no estilo de vida e na diminuição das atividades físicas (FERREIRA; MATSUO; SOUZA, 2011). Em concordância com o quadro mundial, foram detectadas também altas taxas de suicídio na população indígena, que para Ferreira, Matsuo e Souza (2011, p. 2336) ocorrem devido “...à destruição da cultura causada pela perda de seus antigos territórios e aos problemas gerados pelo confinamento compulsório em pequenas áreas de terra em que se encontram atualmente".

Neste contexto, a investigação do legado de participação nos JPI é oportuna, pois eventos dessa dimensão que possuem os indígenas como protagonistas podem oferecer algum retorno aos povos e às comunidades indígenas ao estimular a prática de atividades esportivas (RUHANEN; WHITFORD, 2011). Referente à saúde mental é viável dizer que “...a inclusão de performances culturais indígenas, alimentos, arte e artesanato no festival, ao lado do componente esportivo, reforçam a identidade cultural, o orgulho da comunidade e o sentimento de pertença” (RUHANEN; WHITFORD, 2011, p. 46).

O estudo de Ruhanen e Whitford (2011) citado anteriormente, sobre o Festival Anual de Esportes e Cultura realizado na Austrália, apresenta como duas das principais características citadas dos entrevistados a participação esportiva e a oportunidade de se envolver em atividades físicas. Isto significa dizer que se houver um legado de participação resultante dos JPI, isso poderá contribuir positivamente na saúde física das comunidades indígenas como uma maneira de combater possíveis doenças crônicas-degenerativas. Em concordância, Ferreira e Vinha (2015, p. 243) destacam que os JPI podem ter influências positivas sobre a saúde social dos indígenas, pois representam um contexto onde é possível realizar "[...] vínculos com o ambiente de pertencimento, no qual todos se conhecem, se influenciam mutuamente e cuja participação está carregada de significados, promovendo experiências que são incorporadas pelo grupo e pelo indivíduo.”

A visão amplificada sobre saúde e a não restrição do conceito apenas aos aspectos mentais ou físicos é importante. A importância dos legados dos JPI também está direcionada à saúde social, como citado acima. A autora Vinha (2015, p. 230) ressalta a necessidade do afastamento do conceito de saúde de uma visão eurocêntria e reducionista, no qual "[...] a 
valorização de ambos os saberes, indígena e ocidental, com suas semelhanças e diferenças, é o caminho que possibilita o diálogo intercultural [...]".

Vinha (2015) relaciona os jogos tradicionais com a saúde social, os quais podem contribuir para o fortalecimento das comunidades e das identidades culturais destes povos. Segundo a autora, os JPI têm suas raízes fortemente vinculadas à saúde social de cada povo participante, onde Vinha (2015, p. 243) diz:

"[...] conhecimento tradicional presente nos jogos tradicionais requer, também, vínculos com o ambiente de pertencimento, no qual todos se conhecem, se influenciam mutuamente e cuja participação está carregada de significados, promovendo experiências que são incorporadas pelo grupo e pelo indivíduo."

Segundo Levi (2015), contraditoriamente à previsão histórica que as culturas indígenas se extinguiriam com a completa adesão aos sistemas culturais impostos, eventos como os jogos indígenas contribuem para potencializar a indianidade destes povos por meio de elementos de inovação e criatividade presentes nos jogos. Neste contexto, Levi (2015) destaca o desenvolvimento da autoconsciência étnica e cultural como uma necessidade para a continuidade dos povos indígenas. Levi (2015) propõe que os jogos indígenas estão situados no movimento de afirmação cultural indígena.

Ruhanen e Whitford (2011) relatam que eventos esportivos indígenas possibilitam o desenvolvimento do capital social, da interação social, melhoram a autoestima, tem a capacidade de diminuir o tédio e aumentar o sentimento de pertença, possibilita a reunião com outras comunidades indígenas, além de ser um espaço para promoção e preservação da cultura. Segundo Ruhanen e Whitford (2011) eventos esportivos indígenas são mais passíveis de contribuir no capital social e na qualidade de vida do que eventos esportivos comuns, pelo menos no que consta na literatura acadêmica. Esta alegação é defendida com base na mistura positiva de dois componentes: a cultura e o esporte.

Pertinente ao legado cultural dos JPI a ludodiversidade é preservada no momento em que se incluem modalidades tradicionais relacionadas à sobrevivência, rituais sagrados e outras atividades (FERREIRA; VINHA, 2015). Contudo, o futebol mesmo sendo uma modalidade não indígena, muito praticado nas aldeias, também é um instrumento de preservação da cultura indígena uma vez que a sua prática passa por uma ressignificação em 
cada grupo. Os JPI buscam a celebração e o jogo lúdico com organização, mas sem a rigidez de regras como acontece no esporte ocidental, com o intuito de valorizar a identidade cultural indígena (FERREIRA; VINHA, 2015).

Neste mesmo direcionamento, em um estudo da atração indígena pelo futebol, Vianna (2001) reflete sobre a possível influência do futebol na adesão de outros sentidos e significados na tradicional corrida de toras praticada pelos Xavante. Vianna (2001) reconhece que as práticas socioculturais passam por uma ressignificação, ou seja, adquirem significados distintos conforme os contextos históricos, e que nos processos de "bolização" das toras e "torização" das bolas (expressões usadas pelo autor) o que menos importa é a dimensão da esportivização. Isso significa dizer que se o futebol não é uma prática tradicional, contudo “... isso não impede o surgimento de formulações e iniciativas que apontam para a potencial existência de um futebol xavante..." (VIANNA 2001, p. 321). Com esta denominação de futebol xavante trazida por Vianna (2001), ele reflete que o significado do futebol para estas comunidades vai muito além de uma ameaça à identidade indígena, no qual o futebol ressignificado é transformado como meio em potencial para expressar ainda mais a cultura Xavante.

Sob o mesmo ponto de vista, em um estudo sobre jogos indígenas, desenvolvido com professores indígenas em formação no Curso de Licenciatura, Grando (2010) traz uma reflexão com intuito de verificar as relações entre a cultura lúdica e as mudanças socioculturais da comunidade. Este estudo foi realizado por meio do levantamento de memórias com os parentes dos professores que tinham entre 25 e 92 anos de idade. A característica que mais difere o jogo do futebol, citado acima por Vianna (2001), está no seu aspecto lúdico. Uma das características gerais entre todos os povos, percebida por meio dos jogos analisados nas entrevistas é o reconhecimento da importância do brincar (jogo) pelos os mais velhos na educação dos mais jovens nas tradições do seu povo. Embora algumas brincadeiras tenham tido influência da comunidade não indígena, elas assumem significados diferentes quando vivenciadas pelos indígenas. Por exemplo, o brincar da natação e da canoagem praticada pelo Povo Rikbatsa está ligada à sua sobrevivência, à história de seu povo e à identificação com seus antepassados (GRANDO, 2010).

A chegada do esporte nas comunidades indígenas pode gerar tensões entre as opiniões dos mais velhos e a opinião dos mais jovens. Como relata Vinha e Ferreira (2003), a chegada do esporte para o grupo indígena Kadwéu, na opinião dos mais idosos, estava se igualando ao interesse pelas práticas culturais ou até mesmo se sobrepondo a elas. Vinha e Ferreira (2003), relatam um aumento do interesse dos indígenas Kadwéu mais jovens pelo futebol em 
comparação às práticas corporais, no qual foi constatado que $70 \%$ dos jogos tradicionais estavam em desuso. Contudo, para Vinha e Ferreira (2003, p.155), esta preferência parece estar mais relacionada “... pelos desafios que o esporte promove do que pela rejeição à cultura". Neste processo a interculturalidade também acarretou mudanças no estilo de vida, como referenciado anteriormente, trazendo doenças hipocinéticas, no qual segundo Vinha (2004, p. 250), o xamã não consegue mais solucionar, o que "requer que lhes sejam asseguradas construções de novos saberes, vindos da interculturalidade". Vinha e Ferreira (2003, p. 155), refletem que o esporte pode trazer mudanças como o afastamento dos jovens dos valores tradicionais, mas que no caso dos Kadiwéu eles seriam superiores a estas ameaças, ao compreenderem estas tensões e ressignificá-las que "certamente movimentarão a dinâmica mitológica, trazendo novos sentidos para os sujeitos Kaiwéu”.

Existem algumas mudanças quando algumas práticas são realizadas dentro das comunidades e nos JPI. Como ocorre com a corrida, que nos JPI foram disputadas competitivamente, mas nas aldeias elas têm outro significado onde "....as capacidades por elas exigidas, como velocidade e resistência, estão relacionadas com mitos de diversas culturas, nas quais os dons que são recebidos pelas pessoas indígenas constituem sua identidade de acordo com as representações sociais" (ALMEIDA; ALMEIDA; GRANDO, 2010, p. 68). As características de esporte de alto rendimento presentes nos JPI geram alterações nas práticas sociais das aldeias, como observado nas entrevistas realizadas com um indígena Bororo e um Xavante, que relatam o treinamento de algumas modalidades para a participação nos JPI. De acordo com Almeida, Almeida e Grando (2010) as mudanças culturais são naturais nestes processos de interação com outras culturas, porém a cultura de alto rendimento do esporte presente nos JPI no processo de ressignificação das práticas corporais sofre a incorporação de valores modernos, alterando o significado das práticas corporais tradicionais.

Segundo Gruppi (2013), a afirmação de Almeida, Almeida e Grando (2010) sobre a esportivização das práticas corporais nos JPI, suscitou debates entre os idealizadores e pesquisadores dos jogos, pois o objetivo das práticas tradicionais, segundo os idealizadores dos JPI, é a representação de elementos da vida social, de rituais e cerimônias. Por meio da pesquisa de Gruppi (2013) é possível observar que os organizadores não indígenas são cuidadosos na administração e contam com o auxílio dos indígenas para que se priorizem as características das práticas tradicionais no evento, embora em algumas entrevistas com os envolvidos nos JPI, é observado a contradição entre os termos competição e tradicional relacionados à maneira como vão ser desenvolvidas. Gruppi (2013) não considera que as práticas desenvolvidas nos JPI se constituam ou sejam consideradas como esportivizadas, pois 
as práticas corporais vão além do conceito de esporte de alto rendimento, mas um momento de celebração com outros povos.

Dentro deste aspecto, Vinha (2004) reflete sobre possíveis mudanças ocorridas na apresentação de jogos tradicionais, no qual estas apresentações são realizadas a partir de um filtro permitido de pajés e lideranças indígenas. Um dos exemplos citados por Vinha (2004) é o jogo popular cabo-de-guerra, que na IV e V edição passou a ser a dotado por todos os grupos indígenas participantes. Para Vinha (2004, p. 202), quando a expressão "nossos esportes tradicionais" é usada pelos indígenas, é importante compreender que ela é construída por sentidos oriundos das:

[...] forças da mídia [marketing, economia, espetáculo, entre outros], por políticas públicas que a justificam e por leis que trabalham esse imaginário, configurando a forma de expressar. Indica também um novo processo, ainda esboçante, o da esportização. São vestígios da influência do fenômeno esporte, mas ainda não totalmente claros, carecendo de estudos.

Contudo, é importante entender os significados diferenciados do mundo indígena e ao mesmo tempo ter a compreensão sob uma perspectiva intercultural e que este mundo possui influências externas (BUITRAGO, 2013). A reflexão sobre o corpo no contexto dos JPI é um caminho para a construção do entendimento sobre práticas corporais, pois "a concepção de corpo nas sociedades indígenas corresponde e está ligada à sua concepção de pessoa que não é a mesma das sociedades ocidentais urbanas" (MALUF, 2001, p. 93). Ao mesmo tempo que conceber esta ideia de corpo diferenciada, permite um caminho para entender os possíveis legados de participação advindos dos JPI.

O objetivo desta pesquisa é descrever como a mídia brasileira tem representado os Jogos dos Povos Indígenas. Neste contexto, entender o corpo indígena, as práticas corporais das etnias brasileiras e etno-desporto se torna importante. A mídia pode ter uma visão única ou várias visões do corpo indígena e da associação deste com as práticas esportivas.

O objetivo da abordagem do corpo, com o aporte da antropologia, possui o intuito de tentar compreender os fenômenos culturais específicos destes povos e refletir sobre as noções chamadas ocidentais e modernas. Como relata Maluf (2001, p. 91) este tipo de abordagem “[...] pode nos ajudar ir além de uma comparação limitada às formas do fazer, às técnicas do corpo, para uma comparação sobre as próprias concepções e pensamentos culturais em torno do corpo." 
Nesta concepção, na antropologia um dos autores pioneiros é o francês Marcel Mauss. Em sua obra "As técnicas do corpo", Mauss (2003) reflete sobre a necessidade de ter um tríplice ponto de vista sobre o que é o corpo, ou seja, ter uma a visão do que ele denomina de homem total. Esta visão inclui além da dimensão biológica, a dimensão social e psicológica. Para Mauss (2003), a arte de se dominar o corpo humano está relacionada mais à educação do que a imitação. Mauss (2003) discorre, que mesmo um ato sendo exclusivamente biológico, o ato é imposto de fora, no qual não existiria uma maneira natural de se realizar determinado movimento, mas uma maneira aprendida. O corpo humano seria o primeiro instrumento o qual incidem técnicas e o mais natural objeto do ser humano (MAUSS, 2003).

No que tange a abordagem acerca dos povos indígenas sul-americanos é importante destacar o Simpósio de Antropologia com o tema: A pesquisa etnológica no Brasil. Viveiros de Castro (1979), apresenta o trabalho intitulado "A fabricação do corpo na sociedade Xinguana", no qual o autor trata o corpo como algo fabricado, literalmente fabricado, modelado pela cultura. Este trabalho é de grande importância, pois os conceitos clássicos da Antropologia já não eram suficientes para explicar os traços estruturais dos povos deste continente. O desenvolvimento do trabalho de Viveiros de Castro (1979), pode ser visto como um olhar mais atento às características destes povos, no qual é possível realizar uma análise mais flexível.

Para Viveiros de Castro (1979) existe um sistema de três termos na produção do corpo xinguano. O primeiro deles é a fabricação do corpo, que ocorreria no espaço social denominado periferia, ou seja, no espaço doméstico privado. Neste processo a elaboração do corpo acontece com a reclusão para mudança do corpo. Na fabricação do corpo a manipulação de substâncias, ou simplesmente a entrada ou saída delas é de interesse da sociedade. Por exemplo, segundo os Xinguano os jovens em reclusão pubertária devem se abster de sexo, pois a perda de sêmen pode enfraquecê-los, sob pena de ficarem mais baixos. Outro exemplo, é o tabaco, uma substância considerada xamanística pelos Xinguano, mediadora entre o mundo espiritual e o mundo atual. Sendo assim, é por meio deste processo que os papéis sociais são assumidos.

O segundo processo, denominado metamorfose, ocorre fora da aldeia, quando os Xinguano estão isolados da sociedade. De acordo com Viveiros de Castro (1979, p. 41), assim como a fabricação a metamorfose é também criação: 
como transcendência."

A decoração é o terceiro processo que ocorre no espaço social praça. Este processo consiste na apresentação à vida publica, o confronto com outras aldeias da região e o cerimonial. As pinturas e os adornos vão definir sexo, idade e papel cerimonial. Este processo é o oposto ao da fabricação, pois no momento da reclusão os Xinguano não se pintam e nem se adornam, estão nus.

Em um trabalho mais contemporâneo, Lima (2002), no artigo sobre a noção de corpo para os Juruna, relata sobre o corpo não representar a parte visível por oposição a uma parte invisível. Esta dicotomia de corpo e alma, presente no trabalho de Viveiros de Castro (1979), não é um a realidade para os Juruna. Lima (2002) exemplifica, que na cosmologia Juruna, entre uma piranha ${ }^{1}$ e um guariba ${ }^{2}$, não há diferença entre a alma e o corpo. De acordo com Lima (2002), na etnografia Juruna é possível um homem se transformar em onça ou arara, já que é possível vestir uma outra pele, onde a visibilidade ou invisibilidade do corpo vai depender da capacidade do observador. Neste contexto a alma é uma parte do corpo ou um componente da pessoa, enquanto a pele é um invólucro que unifica as partes e confere ao corpo uma identidade específica.

O fato é que a construção do corpo na concepção destes povos tem características únicas que contribuem para a formação de um processo social, no qual é importante o reconhecimento destas diferenças. A compreensão destas especificidades é um caminho para o entendimento sobre as práticas corporais. Segundo Fassheber (2006) todos estes mecanismos (perfurações, tatuagens, amputações, naturezas desumanizadas, roupas sociais, marginalidades xamanísticas e o uso de psico-ativos) são formas que cada povo indígena possui para construir sua noção de corpo aliada à sua própria noção de pessoa.

Antes de se tentar definir o que são práticas corporais é preciso entender primeiramente que os indígenas brasileiros pertencem a variadas etnias e cada etnia tem sua vivência cultural específica. É necessário desfazer os estereótipos de uma visão uniformizadora (ALMEIDA; ALMEIDA; GRANDO, 2010), que vê os povos indígenas como uma caricatura de cocar e penacho, desconsiderando a diversidade cultural das etnias.

Segundo dados do Instituto Brasileiro de Geografia e Estatística (IBGE) do Censo de 2010, o Brasil tem 896,9 mil indígenas em todo o território nacional, somando a população

\footnotetext{
${ }^{1}$ peixe (Serrasalmus nattereri) encontrado nas bacias do Amazonas, Paraná e São Francisco, vermelho, com cabeça e dorso acinzentados e até $20 \mathrm{~cm}$ de comprimento.

${ }^{2}$ Denominação comum a vários macacos da América do Sul e Central, com cinco espécies no Brasil.
} 
residente tanto em terras indígenas $(63,8 \%)$ quanto em cidades (36,2\%). Do total, 817,9 mil se autodeclararam índios no quesito cor ou raça e 78,9 mil, embora se declarassem de outra cor ou raça, principalmente parda $(67,5 \%)$, se consideram indígenas pelas tradições e costumes.

Em relação às etnias, o IBGE (2010) investigou pela primeira vez no último censo o número de etnias indígenas, encontrando 305 etnias. Do total de indígenas declarados ou considerados, 672,5 mil (75\%) declararam o nome da etnia, 147,2 mil (16,4\%) não sabiam e 53,8 mil (6\%) não declararam.

A maior etnia é a Tikúna, com $6,8 \%$ da população indígena. Também foram identificadas 274 línguas, sendo a Tikúna a mais falada (34,1 mil pessoas). Dos 786,7 mil indígenas de 5 anos ou mais, 37,4\% falam uma língua indígena e 76,9\% falam português.

Neste caminho, a elucidação das terminologias Indígena, Autóctone, Primitivo e Aborígene também são necessárias, pois segundo Buitrago (2013) estas definições possuem conceitos muito próximos.

Outro ponto a ser destacado, é o fato destas terminologias serem usadas de forma equivocada, tendo como base apenas o senso comum, arraigado muitas vezes de preconceito (XIMENES, 2011). Sendo assim, a diferenciação entre estas terminologias são importantes. Para melhor visualização, segue abaixo figura que explica sobre as definições destas terminologias elaboradas (BUITRAGO, 2013, p. 46). 
Figura 2 - Esquema explicativo sobre as terminologias indígena, autóctone, primitivo e aborígene

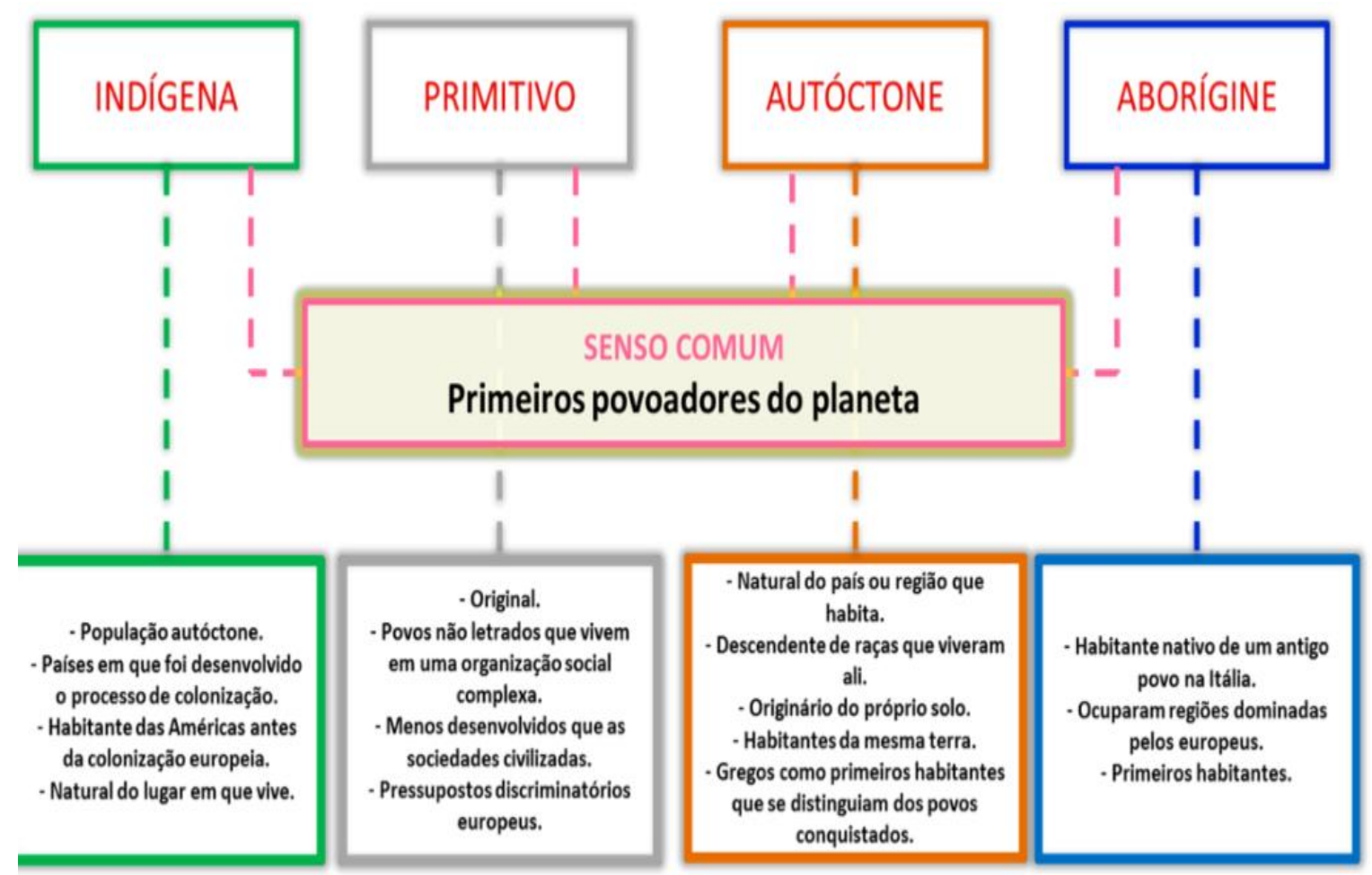

1 Todas as acepções fazem referência a algo próprio, de habitantes de um país ou local determinado.

2 Tanto o conceito Indígena quanto o Aborígine ressaltam particularmente o sentido daqueles habitantes da América colonizados pelos países europeus.

3 antiguidade, como distinção daqueles povos invadidos e conquistados da Europa. Porém deixa-se entrever que na época se apresentavam várias dicotomias (civilizado/bárbaro estrangeiro/local).

O Primitivo faz referência aos habitantes e povos originários de um local determinado,

4 apresentando um sentido desdenhoso com relação à falta de humanidade (inumanidade) representada por raças (povos) não civilizadas, razão suficiente para ser invadidos pelos países europeus.

Fonte: Buitrago (2013, p. 46). 
Retomando o conceito de práticas corporais é possível dizer que este termo é pesquisado com maior frequência no campo da Educação Física, no qual os artigos e periódicos o utilizam realizando uma ligação com as ciências humanas e sociais, porém em cada área que é abordado recebe um significado diferente (LAZZAROTTI FILHO et al., 2010). Na área da saúde, o termo "práticas corporais" aparece relacionado com preocupações ligadas ao corpo, mas quando vinculado à antropologia aparece como sinônimo de técnicas corporais (LAZZAROTTI FILHO et al., 2010). Em uma visão geral o conceito de práticas corporais vem sendo atribuído a movimentos ou atividades que:

[...] vão desde as mais tradicionais (práticas adestradoras; precisas e sistematizadas de marcante caráter racional e higiênico; competitivas; práticas corporais mais remotas), até as ressignificadas, indicando ou não uma relação com a Educação Física (práticas corporais diárias; cotidianas; humanas; na maternidade; de diferentes culturas, ocidentais e orientais) (LAZZAROTTI FILHO et al., 2010, p. 24).

Concernente aos JPI, as práticas corporais podem ter significados dentro de determinados contextos, no qual se pode pensar no esporte por meio de outra abordagem (GRUPPI, 2013). A exemplo de práticas corporais formais ou tradicionais indígenas e às práticas ocidentais realizadas nos JPI, Gruppi (2013, p. 110) relata que as primeiras "são as que fazem parte de seus rituais" enquanto que as práticas 'ocidentais' são aquelas importadas de outras culturas, tais como o futebol, voleibol e a natação. As práticas corporais tradicionais são trazidas das aldeias com autorização dos caciques e quando realizadas nos JPI atendem ao objetivo do local onde acontecerão, ou seja, se elas acontecerão em uma arena ou outro lugar determinado pelos organizadores. As práticas corporais intencionam representar a cultura no JPI proporcionando a troca de conhecimento entre os indígenas e os não indígenas (GRUPPI, 2013).

Em concordância com o exposto acima, as práticas corporais foram divididas por Pinto e Grando (2011), como: a) práticas corporais tradicionais ou jogos autóctones, que são aquelas onde não há possibilidades para normatização, por serem restritas a determinados grupos e por terem se desenvolvido em forma de apresentação; e b) atividades competitivas, que são as atividades esportivas e passíveis de promover desafios entre etnias (como arco e flecha e a canoagem). As práticas corporais tradicionais que ocorrem nos JPI estão relacionadas à sobrevivência indígena e aos rituais sagrados (como lutas e corrida de tora), às brincadeiras e aos jogos demonstrativos; bem como outras atividades do dia a dia como: jogos com bola, cabo de guerra/de força, natação e zarabatana. As atividades competitivas incluem 
modalidades esportivas não indígenas que são vivenciadas nas aldeias como, por exemplo, o futebol (PINTO; GRANDO, 2011).

Segundo Almeida, Almeida e Grando (2010, p. 67) os jogos e brincadeiras tradicionais podem ser compreendidos como:

[...] um conjunto de hábitos e práticas que têm como significado uma relação simbiótica entre corpo e espírito, posto que algumas lutas corporais, as corridas e alguns jogos tradicionais presumem uma explicação mitológica para sua realização; são meios de interação entre o mundo dos espíritos e o mundo real que ocorre durante os rituais indígenas.

Neste contexto, o termo tradicional está relacionado à maneira como o jogo é adquirido e usado, a prática dos jogos tradicionais para os indígenas está ligada à sua vivência cotidiana, como define Rocha Ferreira et al. (2005, p. 33):

Os jogos tradicionais indígenas são atividades corporais, com características lúdicas, pelas quais permeiam os mitos e valores culturais. Eles requerem um aprendizado específico de habilidades motoras, estratégias e/ou chances. Geralmente, são jogados em rituais, para agradar a um ser sobrenatural e/ou para obter fertilidade, chuva, alimentos, saúde, condicionamento físico, sucesso na guerra, entre outros. Visam, também, a preparação do jovem para a vida adulta, a socialização, a cooperação e/ou a formação de guerreiros.

Outra diferenciação importante a ser estabelecida é entre jogo popular e jogo tradicional. De acordo com Vinha (2013), o jogo popular está para a sociedade não indígena enquanto o jogo tradicional estaria voltado para as sociedades indígenas. Segundo Vinha (2013, p. 61) o jogo popular pode ser entendido como:

\footnotetext{
"[...] jogo que marca uma sociedade ou grupo social, sendo repassado intra e intergerações, realizado nos espaços da rua, da escola, entre familiares e na vizinhança. Sua origem é pouco buscada, podendo vir de uma ou de diversas culturas, contudo é disseminado e praticado em diferentes povos, sociedades e grupos, adaptando-se aos espaços, materiais, quantidade de participantes, normas e com alteração dos cânticos e ritmos[...]"
}

Vinha (2013) destaca ainda, outro tipo de jogo, o jogo denominado adotado. A autora realiza uma análise sobre a compreensão dos jogos serem criações externas e internas. No qual as criações externas estariam envolvidas às atividades criadas no interior da situação existencial. Neste contexto, Vinha (2013) caracteriza o jogo cabo-de-guerra como um jogo adotado.

Contudo, para Buitrago (2013) existe diferença entre jogos autóctones e jogos tradicionais. $\mathrm{O}$ autor expõe o relato de um colaborador com um tipo de jogo realizado no rio 
Amazonas com botos cor de rosa para exemplificar os jogos autóctones. Na narrativa do colaborador, o jogo consistia em brincar no rio e quando supostamente os botos cor de rosa se aproximassem eles tentariam fugir. Segundo algumas crenças estes animais têm poderes mágicos, que possibilitam o boto se transformar em homem quando está fora da água. Segundo Buitrago (2013, p. 92), estes jogos possuem características de relação interacional com animais, seres mitológicos, onde está presente o extra humano, “[...] processo que articula cosmologia, natureza e lendas que se visualizam neste tipo de animal." Sendo assim, de acordo com Buitrago (2013) no sentido de levar a manifestação extra-humana presente nos jogos autóctones o autor coloca esta característica como diferenciadora dos jogos tradicionais.

Para a construção dos JPI, Carlos Justino Terena, em entrevista para Camargo et al. (2010), relata que foram anos de pesquisas para conhecer a peculiaridade cultural de cada povo, formatar e organizar o evento, sob todos os aspectos: organização social, língua, danças, cantos, filosofias, ritos, crenças, espiritualidades e, principalmente, os esportes tradicionais. Almeida, Almeida e Grando (2010) afirmam que no contexto dos JPI, as práticas corporais assumem características de esporte de alto rendimento o que pode modificar a relação do indígena com uso de seu corpo. Para os indígenas, os jogos e brincadeiras, ou seja, as práticas corporais, "são entendidas como elementos da cultura corporal de cada etnia indígena, portanto assumem sentidos e significados de acordo com o contexto social no qual são vivenciadas" (ALMEIDA; ALMEIDA; GRANDO, 2010, p. 3).

De acordo com Buitrago (2013, p.49), estas elucidações sobre as práticas corporais indígenas são importantes para uma melhor interpretação do mundo acadêmico dos significados do mundo indígena:

“[...] a finalidade de atribuir inteligibilidade às manifestações corporais próprias dos diversos povos da comunidade pesquisada, razão pela qual é necessário seu uso para tentar fazer compreender/traduzir o significado que estas práticas têm na construção dos seus bens culturais.” Buitrago (2013, p. 49)

Pode-se observar que alguns dos jogos presentes nos JPI apresentam características de quantificação, racionalização e até mesmo a busca por recordes, consideradas por Guttman (2004) como qualidades do esporte moderno. Um exemplo, é quando nos JPI procura-se usar canoas fabricadas com o mesmo tipo de madeira em um mesmo formato, embora em algumas aldeias a fabriquem de forma diferente. Este pode ser considerado um tipo de padronização para que todos possam competir de forma igualitária. Com base no exposto, pode não ser equivocado dizer que os JPI seriam um evento esportivo, mas talvez uma classificação 
incompleta. Assim, devido as suas nuances muito específicas, pode ser mais apropriado, ao tentar classificar os JPI e entender seus possíveis legados de participação, não conceituá-lo apenas desta forma, colocando-o juntamente à classificação com outros eventos esportivos. A conexão pra entender um evento desta natureza, pelo olhar da gestão esportiva, talvez seja considerá-lo, com suporte antropológico, como sendo um evento esportivo não mega denominado como etno-desporto. Este conceito já é conhecido pela literatura acadêmica como etno-esporte ou endocultura (Vinha, 2004).

Conforme foi visto nas formulações acima arguidas, o fenômeno esporte moderno está imbricado nos JPI com outros sentidos e significados. Como exemplo, do estudo de Vianna (2001) sobre o futebol e a corrida com toras, no qual se fala sobre a "bolização" das toras ou a "torização" das bolas ou por meio de outros processos de esportivização das práticas corporais indígenas. Fassheber (2006) explica estes processos dinâmicos de transformações das práticas tradicionais indígenas e a introdução de esportes modernos na maioria das comunidades indígenas presentes nos JPI, fazendo uma relação entre o etno-desporto com o processo de mimesis.

O etno-desporto indígena pode ser entendido como as manifestações culturais de cada povo ou grupo (VINHA, 2004). Segundo Fassheber (2006), o etno-desporto indígena representa a possibilidade de transformações e adaptações das culturas indígenas assim como as adaptações e transformações das culturas provenientes de fora do seu âmbito social, onde está presente a coexistência do passado com o presente.

A relação de etno-desporto e mimesis pode ser compreendida por meio da obra "A busca da excitação" de Elias e Dunning (1992). Segundo os autores, os sentimentos de excitação são favorecidos pela prática de atividades de lazer e/ou um jogo ao criarem tensões. Os sentimentos como raiva, medo e paz de espírito são dinamizados numa situação imaginária, aflorados em uma situação real representando a mimesis. De acordo com os autores, a mimesis pode ser entendida como a capacidade de proporcionar experiências de emoções vividas em diferentes contextos, onde existe uma excitação controlada mas agradável. Elias e Dunning (1992) discorrem que os esportes de forma geral são uma forma de combate mimético controlado e não violento. De acordo com os autores, esta tensão gerada de forma controlada é finalizada com a liberação da tensão, atendendo à necessidade humana de uma excitação agradável e segura para os outros e para si mesmo. Neste contexto, é possível observar a mimesis da guerra relatado no estudo de Vinha (2013). A autora destaca a 
participação de uma anciã na IV edição (2001) nacional dos JPI. Vinha (2013) reflete sobre o relato da anciã ao ganhar o jogo cabo-de guerra. O relato consiste na comparação feita pela anciã entre a força usada durante o jogo e a força que foi usada durante os 60 anos para a recuperação de suas terras tradicionais.

Ao relacionar o processo de mimesis com o futebol, Fassheber (2006) diz que a mimesis age nas identidades que o jogo pode gerar, ou seja, cria uma segunda natureza do jogo de acordo com cada interpretação e/ou apropriação específicas de cada cultura. Segundo Fassheber (2006), estas identidades seriam "naturalizações" que cada povo realiza para a correspondência com a sua cultura, no qual esta segunda natureza caracteriza o etno-desporto. É importante salientar, que este processo não é mera cópia de um esporte, mas um processo de ressignificação, no qual segundo Fassheber (2006), o esporte ganha significados próprios segundo cada cultura indígena específica.

A mimesis da organização é outra característica dos JPI, onde o contexto em que ele é desenvolvido possui qualidade de eventos esportivos não indígenas. Segundo Fassheber (2006), estão presentes três pontos a partir desta concepção. O primeiro deles está na comunicação entre as comunidades indígenas, onde há a troca de conhecimento de jogos tradicionais entre estas comunidades. O outro ponto, consiste na mudança de algumas características de alguns tipos de jogos, por exemplo os jogos que seriam demonstrativos e/ou cooperativos passam a ter características competitivas. Esta mudança pode ser decorrente da tentativa de chamar a atenção dos não indígenas para o evento com intuito de torná-lo mais próximo de um evento esportivo não indígena. Segundo Fassheber (2006, p. 103), “[...] a mimesis ocorre da necessidade de grafar tradições ágrafas e, não obstante, padronizá-las sob a forma de regras e regulamentos."

O último ponto é o que Fassheber (2006) denomina de duplo mimético. Que ocorreria no momento do contato dos indígenas com a cultura dos "brancos" e no caminho inverso, o contato dos "brancos" com a cultura indígena. O interesse mútuo pelo diferente da outra cultura é observado durante os JPI, ao se analisar o interesse dos indígenas por bens de consumo do comércio local e por outro lado o interesse pelo artesanato indígena pelos "brancos".

Diante deste aprofundamento sobre os JPI e da sua relevância com relação ao legado de participação, a mídia tem potencial de desempenhar um papel de influência na alavancagem deste legado (CHALIP et al. 2017). Nesta concepção, é importante entender como a mídia realiza a construção da imagem dos indígenas. 
Além da possibilidade de ferramenta para alavancagem do legado de participação como relatado acima por Chalip et al. (2017), a mídia também possui um papel social (IJUIM, 2009, p. 32). É importante refletir sobre a abordagem da mídia frente aos povos indígenas, pois a mesma possui um forte poder na formação de opiniões.

Para Ximenes (2011), as imagens feitas do imaginário dos povos indígenas, que os considera como primitivos, preguiçosos, inocentes, indefesos ou visões que os desconsideram da sua posição de indígena devido as mudanças culturais que sofreram são contruções realizadas ao longo da história. Ximenes (2011, p. 1), relata três momentos:

\footnotetext{
O primeiro item refere-se à expansão europeia, principalmente portuguesa, via Atlântico e o imaginário dos primeiros contatos com os indígenas. O segundo item abrange as mudanças do pensamento ocidental e as novas considerações sobre os índios neste paradigma. O terceiro e último item apresenta uma reflexão acerca do imaginário sobre os povos indígenas no Brasil contemporâneo.
}

Por outro lado, como relata Ximenes (2011), é importante dismistificar também a concepção que caracteriza os indígenas como vítimas ou agentes passivos nestes processos históricos, pois os indígenas foram e são sujeitos da sua trajetória. Para Ximenes (2011), embora a história tenha os renegado a um papel menor, os indígenas também se mobilizaram em função dos seus projetos de vida.

Neste contexto, em um estudo sobre as representações sociais e o discurso midiático sobre indígenas, Melo (2008) realiza uma abordagem de dois jornais de Pernambuco com relação à visibilidade que os indígenas conseguem ter acerca de seus sistemas de valores. Segundo Melo (2008), se a discussão na esfera pública ideal se alinhasse ao discursso da mídia, minorias teriam maior espaço de fala. Contudo, de acordo com Melo (2008), o discurso da mídia reforça a ideologia dominante, no qual os grupos excluídos só têm abertura nas concessões que a imprensa faz, apresentando uma realidade fragmentada. Melo (2008, p. 5), em análise dos jornais Diário de Pernambuco e Jornal do Commercio no período de julho de 2001 a abril de 2002, diz que apenas temáticas indígenas muito específicas entram em vigor nas reportagens:

[...] em primeiro lugar, quando é vítima ou autor de violência; em segundo, quando representa algo exótico ou inusitado, ou seja, no enfoque do inesperado. Questões como saúde, educação, ciência, terra e cultura indígenas não são enfocadas ou são tratadas segundo o senso comum formado sobre o índio, conceitos concebidos a partir da ideologia da classe dominante, no qual vigora um senso comum que reflete o pensamento e as idéias dessa classe dominante. 
Segundo Melo (2008), isso decorreria em virtude de uma leitura do indígena baseada no senso comum e arraigada de preconceito, no qual os indígenas são uma fonte passiva na abordagem da mídia, ou seja, não conseguem verbalizar seu discurso.

A pesquisa de Freire (2019a), que resultou no livro "A construção de um réu: Payakã e os índios na imprensa Brasileira", parece reforçar o que diz Melo (2008), quando se fala na visão da mídia com base na ideologia dos grupos dominantes. Freire (2019a) também realiza uma abordagem sobre uma visão estereotipada com relação aos indígenas. De acordo com Freire (2019a), as construções são oportunamente realizadas pela imprensa, assim como os indígenas são tratados como selvagens, eles também são tratados como ricos e privilegiados, como no caso da cobertura da imprensa no crime imputado pelo indígena Payakã. No caso de Payakã, Freire (2019b) observou que não houve um tratamento especial às questões éticas, assim como não foi constatado o interesse da imprenssa em fontes alternativas para o tratamento do caso.

No mesmo direcionamento de Melo (2008), Batista, Silva e Simas (2015) analisaram a imagem do indígena no portal Notícias Agrícolas, onde foi constatado mais uma vez, por parte da mídia, uma construção estereotipada. Batista, Silva e Simas (2015) relatam que as reportagens abordaram os indígenas como violentos ou reforçaram a ideia de que os indígenas não existem mais. Segundo Batista, Silva e Simas (2015), para reafirmar este pensamento, as reportagens usaram expressões como "indigenóides", ou seja, o que eles consideram como invenções de indígenas, com o objetivo de deslegitimar os direitos deste grupo. Batista, Silva e Simas (2015) dizem que o Notícias Agrícolas utiliza dos estereótipos historicamente construídos para manipular as informações com o objetivo de atender aos grupos dominantes.

Pode parecer óbvio que as análises das reportagens do Notícias Agrícolas seriam tendenciosas, uma vez que este portal de notícias atende a interesses do agronegócio, contudo esta propensão não é exclusiva deste tipo de mídia. O trabalho de Klein (2008) também corrobora o que foi proposto por Melo (2008), a respeito da baixa possibilidade de protagonização na mídia e a construção da imagem dos indígenas com base no imaginário formado pelo senso comum.

Dentro desta mesma perspectiva, mas com o foco na recorrência de publicações negativas em torno das temáticas indígenas, Costa e Santos (2015) abordam sobre o tratamento editorial dado pelo jornal impresso Gazeta de Alagoas a estas temáticas. Costa e Santos (2015), relatam que as reportagens em sua maioria trataram sobre os indígenas em zonas de conflito e usaram adjetivos como brigões, invasores e desordeiros para retratá-los.

Uma população indígena pouco expressiva, seria um outro ponto a ser especulado na 
interferência da cobertura da mídia, porém o que é observado, é que este tipo de cobertura da mídia está relacionada com a construção histórica baseada em estereótipos e difundida pelos meios de comunicação desde seus primórdios. Ao encontro desta premissa, Pacheco e Munaro (2015) analisaram reportagens de oito edições do jornal imprenso Folha de Boa Vista entre os dias 13 a 20 de abril. Este jornal pertence à capital Boa Vista do Estado de Roraima que, segundo Pacheco e Munaro (2015), é possuidor de uma população indígena que corresponde a 13\% da população, ou seja, uma população indígena expressiva. Pacheco e Munaro (2015) parecem concordar que uma população indígena expressiva não resulta em uma cobertura mais positiva da imprensa sobre temáticas indígenas:

\footnotetext{
De uma forma mais ampla, é possível perceber como, mesmo Roraima sendo o estado com maior parcela de indígenas na sua população e, ao mesmo tempo, onde as heranças indígenas estão presentes de forma fundamental, o jornalismo adota uma postura distante e quase formal, dando pouca voz, em sua estrutura, para o próprio indígena. Quando muito, são convocadas à fala lideranças institucionais, membros de associações urbanas e universitários. (PACHECO; MUNARO, 2015, p. 12)
}

Com o objetivo de salvaguardar as edições dos JPI entre os anos de 1996 a 2009, Gomes (2011) analisou a cobertura da mídia. De acordo com Gomes (2011), a maioria das reportagens abordou temas como disputas e personalidades, mas que temas como saúde também foram tratados. Gomes (2011) relata que algumas reportagens cobriram os JPI de forma pejorativa, como no caso da reportagem "Algumas etnias acreditam que poderão perder a força para a competição caso sejam vacinadas e estão protelando para depois dos jogos”, no qual a autora diz:

\footnotetext{
Ora, isso em parte é querer creditar aos costumes indígenas, e de forma um pouco pejorativa, algo que é perfeitarnente normal, uma vez que temos conhecimento que as vacinas muitas vezes trazem reações alérgicas que deixam o organismo mais debilitado. Também em muitas matérias observamnos a tentativa de dar um ar "jocoso" aos costumes indígenas, e por isso as classificamos como "pitorescas", pois não se tratavam de uma cobertura isenta e objetiva do evento. Identificamos 4 delas como pitorecas, o que corresponde a $10 \%$ do total para os jogos daquele ano (GOMES, 2011, p. 101).
}

Além desta construção estereotipada com relação aos indígenas a mídia também pode ser responsável por fabricações de visões inadequadas quando fazem referências aos JPI. Vinha (2004) discorre sobre estas inadequações que a mídia realiza ao atribuir o nome de esporte ao jogo. Vinha (2004) ressalta como exemplo a reportagem do jornal Folha do Povo ao retratar o jogo tradicional zarabatana como esporte, pois o que ocorre na verdade é uma apresentação do povo Matis, uma vez que este jogo tradicional é pertencente apenas a este povo. De acordo com Vinha (2004), quando a mídia tem o poder de interferir nas regras, 
como as alterações realizadas nos uniformes dos participantes dos JPI, decorrente de uma exigência televisiva, ela possui um potencial tendencioso em tornar tudo um espetáculo vendável. Vinha (2004) considera que o fenômeno esporte também é influenciador na padronização de qualquer atividade física. 
A metodologia usada para elucidação do objetivo da pesquisa foi a análise de conteúdo de reportagens dos meios de comunicação que cobriram os JPI. Segundo Bardin (1977), ao realizar um panorama histórico, o surgimento da análise de conteúdo ocorreu nos Estados Unidos. De acordo com Bardin (1997, p. 11), Harold Dwight Lasswell “...fez análises de imprensa e propaganda desde 1915 aproximadamente. Em 1927 é editado: "Propaganda Technique in the World War". E pode ser considerado como primeiro nome que de fato demonstra a história da análise de conteúdo da mídia.

A opção pela análise de conteúdo para a metodologia desta pesquisa está direcionada ao seu caráter social, ou seja, à sua capacidade de incorporar o significado e a intencionalidade às relações e estruturas sociais (BARDIN, 1977), característica importante devido às especificidades do tema. Outro ponto, é que segundo Bardin (1977), a comunicação de massa, como por exemplo os jornais, são um dos domínios possíveis da aplicação da análise de conteúdo. De acordo com Bardin (1977), a análise de conteúdo contém três fases: a) a pré- análise, b) a exploração do material e c) o tratamento dos resultados, a inferência e a interpretação. A Figura 3 representa o esquema proposto por Bardin (1977, p. 102).

Em concordância com a pré-análise, o primeiro passo realizado foi a leitura flutuante proposta por Bardin (1977). Neste momento foi realizado o contato com diferentes documentos, onde foi permitido ter impressões e realizar anotações relevantes para a pesquisa. A escolha dos documentos, foi realizada mediante a uma pesquisa exploratória, no qual os meios de comunicação e fontes utilizados foram jornais, revistas, arquivos e internet. Informações e documentações também foram consultadas do Comitê Intertribal - Memória e Ciência Indígena e Memorial dos Povos Indígenas e do projeto intitulado "Jogo, Celebração, memória e Identidade: Reconstrução da trajetória de criação, implementação e difusão dos Jogos Indígenas no Brasil (1996 - 2009)"3.

A partir deste momento foi constituído um corpus, definido por Bardin (1977, p. 96) como "o conjunto dos documentos tidos em conta para serem submetidos aos procedimentos analíticos." Contudo, é importante ressaltar a reflexão realizada sobre as quatro regras do corpus, propostas por Bardin (1977), seguidas nesta fase da pesquisa.

\footnotetext{
${ }^{3}$ Acessível em http://www.labjor.unicamp.br
} 
Figura 3 - Esquema de desenvolvimento de uma análise

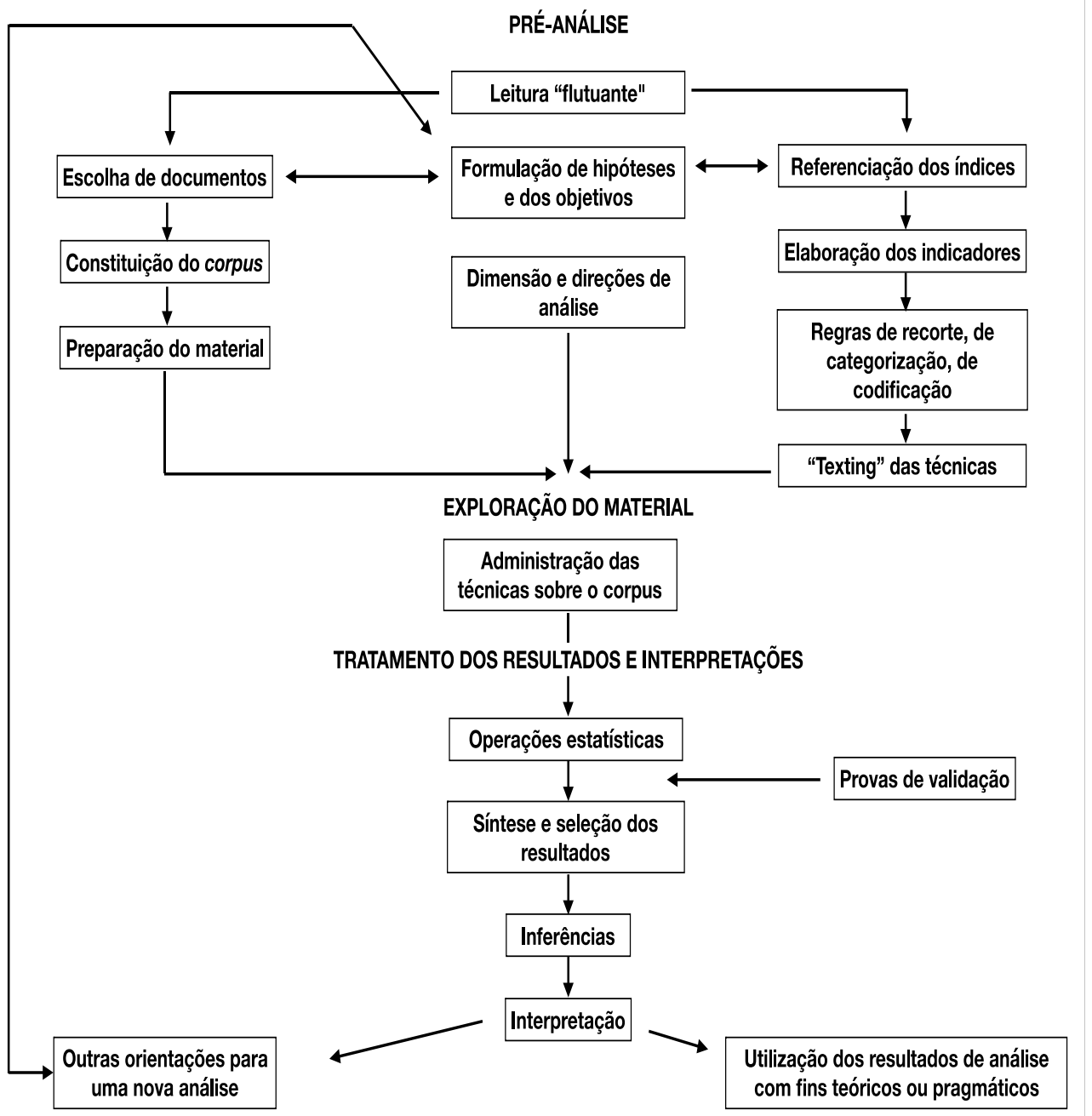

Fonte: Bardin (1977, p. 102).

A primeira delas é a exaustividade. Durante a realização desta fase foi considerado todo elemento do corpus, ou seja, não se excluiu nenhum elemento de forma não justificada ou subjetiva.

A segunda regra é a da representatividade, esta fase teve como entendimento que o corpus retirado representou o universo inical investigado.

A terceira é a regra da homogeineidade, que indica que os documentos devem obedecer à critérios de escolha rigorosos e não apresentar demasiadas singularidades.

Na quarta regra, da pertinência, Bardin (1977) diz que os documentos devem ser adequados de forma a corresponder ao objeto de análise.

Como resultado desta fase as reportagens incluídas atenderam pelo menos um dos cinco critérios dentro das condições possíveis:

1) edições das cidades anfitriãs dos JPI; 
2) edições das cidades próximas à dos JPI;

3) edições de grande circulação;

4) jornais, revistas e portais de grande circulação auditados pelo IVC (Instituto Verificador de Circulação).

5) A cobertura das reportagens das edições dos JPI entre os anos de 1996 a 2013.

$\mathrm{O}$ acesso às reportagens foi realizado integralmente pela Internet entre os dias 07/05/2019 a 12/08/2019. Grande parte do material analisado foi obtido no site do Labjor ( Laboratório de Estudos Avançados em Jornalismo). Este site possui um acervo compilado de reportagens escaneadas que fizeram a cobertura da I edição à X edição dos JPI. O Labjor foi criado na Unicamp, em 1994, como órgão integrante da estrutura do Núcleo de Desenvolvimento da Criatividade (Nudecri) e desenvolve atividades de pós-graduação, pesquisa, extensão, treinamento e consultoria.

Para a seleção das outras reportagens foi realizado um esquema de coleta de dados nas websites google, yahoo, uol, terra e bing. Estes sites foram selecionados por serem considerados alguns dos principais sites de busca. No primeiro passo foi realizada uma pesquisa com as palavras-chaves "jogos indígenas", "jogos dos povos indígenas" e "povos indígenas". Após foram utilizadas palavras-chaves contendo o ano e/ou edição de todas as edições dos JPI, por exemplo, "1996 jogos indígenas”, “1996 jogos dos povos indígenas”, "I edição dos Jogos dos Povos Indígenas”, “I 1996 edição dos Jogos dos Povos Indígenas”.

Nos casos no qual reportagens de jornais acessados pela Internet estavam limitadas, foram realizadas solicitações via e-mail para o acesso total à estas reportagens. Alguns emails não foram respondidos, os que foram respondidos informaram que o acesso total às reportagens seria possível somente diante o pagamento destas reportagens. Sendo assim, é importante relatar que devido a estes fatores o levantamento de dados pode ter sido limitado, o que significa dizer que esta amostra pode não representar a totalidade

Foi formulada uma tabela por edição dos JPI para a coleta de dados. Esta tabela foi dividida em: mídia, data, tema principal, temas secundários, as etnias e modalidades relatadas durante as reportagens. A percepção da reportagem foi considerada positiva ou negativa, dependendo da impressão da pesquisadora se a matéria tratava sobre os JPI, a cultura indígena e/ou os participantes do evento de forma estereotipada (Apêndice A).

Na reflexão sobre a conceituação de Fassheber (2006) e com suporte nas definições discutidas acima, as expressões "evento", "evento cultural" e "jogos" foram consideradas na 
análise de dados como uma definição mais próxima da classificação dos JPI. A utilização desta proximidade foi realizada apenas para tornar a análise mais exequível. Com base na profundidade do conceito de etno-desporto estas classificações não possuem o intuito de serem consideradas totalmente corretas ou erradas, mas simplesmente mais próximas do conceito. As expressões "modalidades esportivas" e "evento esportivo" foram igualadas à classificação "esporte". A expressão "demonstração de ritual” foi igualada a "ritual". Com relação à percepção do conteúdo das reportagens, com base no exposto por Ximenes (2011), esta definição de "real" ou "mais próxima" dos JPI, está relacionada com o conceito contrário à dimensão imaginária da mente humanana, ou seja, o imaginário sobre os povos indígenas. 
Os resultados são apresentados de acordo com os pontos verificados nas reportagens: tema principal e tema secundário abordados nas reportagens, as etnias e modalidades relatadas durante as reportagem, a visão dos meios de comunicação sobre os JPI, ou seja, como os JPI foram classificados pelas reportagens e a percepção que a matéria passou para a pesquisadora - positiva (descrição apropriada dos JPI e da cultura indígena) ou negativa (descrição estereotipada). Foram analisadas 240 reportagens de 60 meios de comunicação diferentes como mostra o Quadro 1 abaixo.

Quadro 1 - Número de reportagens por meio de comunicação

\begin{tabular}{|l|l|l|}
\hline \multicolumn{1}{|c|}{ Jornal } & \multicolumn{1}{|c|}{$\begin{array}{c}\text { Ano da } \\
\text { Edição }\end{array}$} & $\begin{array}{c}\text { No } \\
\text { Reportagens } \\
\text { por Jornal }\end{array}$ \\
\hline Jornal do Tocantins (TO) & 2003 & 45 \\
\hline Ministério do Esporte & 2009 & 21 \\
\hline O Popular (GO) & 1996 & 14 \\
\hline Folha Popular (TO) & 2003 & 14 \\
\hline Jornal Commercio (Recife-PE) & 2007 & 12 \\
\hline Folha de Londrina & 1999 & 11 \\
\hline Correio do Estado (Campo Grande-MS) & 2001 & 11 \\
\hline Portal Stylo (Tocantins-Palmas) & 2011 & 8 \\
\hline $\begin{array}{l}\text { SETRAS (Informativo Mensal Secretaria do Trabalho e Ação } \\
\text { Social da Bahia) }\end{array}$ & 2004 & 7 \\
\hline Olhar Direto (Cuiabá-MT) & 2013 & 7 \\
\hline O Girassol (Palmas-TO) & 2003 & 6 \\
\hline Jornal de Brasília & 1996 & 5 \\
\hline Folha do Povo (Campo Grande-MS) & 2001 & 5 \\
\hline Diário da Manhã (Goiânia) & 1996 & 4 \\
\hline Folha de São Paulo & 1996 & 4 \\
\hline Diário do Pantanal (Campo Grande-MS) & 2001 & 4 \\
\hline O Liberal (Belém-PA) & 2002 & 4 \\
\hline O Popular (Goiania-GO) & 2003 & 4 \\
\hline O Liberal (Belém-PA) & 2000 & 3 \\
\hline O Estadão (RO) & 2003 & 3 \\
\hline Diário do Pará & 2009 & 3 \\
\hline Isto É & 1996 & 2 \\
\hline O Progresso (Dourados-MS) & 2001 & 2 \\
\hline Zero Hora (RS) & 2003 & 2 \\
\hline O Sollo (Porto Seguro) & 2004 & 2 \\
\hline Diário do Nordeste (Ceará) & 2005 & 2 \\
\hline O Liberal (Belém-PA) & 2007 & 2 \\
\hline & & \\
\hline
\end{tabular}




\begin{tabular}{|l|l|l|}
\hline O Liberal (Belém-PA) & 2009 & 2 \\
\hline Arab Times (Estados Unidos) & 1996 & 1 \\
\hline Jornal do Brasil (Rio de Janeiro) & 1996 & 1 \\
\hline O Dia (RJ) & 1996 & 1 \\
\hline O Estadão (MA) & 1996 & 1 \\
\hline O Globo & 1996 & 1 \\
\hline A Notícia (Redenção-PA) & 2000 & 1 \\
\hline Agência Pará & 2000 & 1 \\
\hline O Independente (Conceição do Araguaia-PA) & 2000 & 1 \\
\hline Jornal Web RMT Online (Campo Grande-MS) & 2001 & 1 \\
\hline O Liberal (Belém-PA) & 2001 & 1 \\
\hline Primeira hora (Campo Grande-MS) & 2001 & 1 \\
\hline A Crítica (AM) & 2003 & 1 \\
\hline A Gazeta (ES) & 2003 & 1 \\
\hline Folha de São Paulo & 2003 & 1 \\
\hline Gazeta do Povo (PR) & 2003 & 1 \\
\hline Jornal de Brasília & 2003 & 1 \\
\hline Jornal dos Sports & 2003 & 1 \\
\hline O Estado de São Paulo & 2003 & 1 \\
\hline Globo Rural & 2009 & 1 \\
\hline Inbrapi (Instituto Indígena Brasileiro para Propriedade & 2009 & 1 \\
\hline Intelectual) & & \\
\hline Jornal Local (Campinas) & 2009 & 1 \\
\hline Jornal O Rebate & 2009 & 1 \\
\hline Nossacara (Jornal online Bahia) & 2009 & 1 \\
\hline The Observer (Reino Unido) & 2009 & 1 \\
\hline UOL & 2009 & 1 \\
\hline Portal Terra & 2011 & 1 \\
\hline G1 & 2011 & 1 \\
\hline O Globo & 2011 & 1 \\
\hline Correio Cacerense (Cáceres/MT) & 2013 & 1 \\
\hline Gazeta Digital (Cuiabá/MT) & 2013 & 1 \\
\hline Hipernotícias (Cuiabá / MT) & 2013 & 1 \\
\hline TOTAL & & 240 \\
\hline & & \\
\hline
\end{tabular}

Contudo é importante relatar que devido a fatores como solicitações não atendidas por parte de alguns meios de comunicação e a exigência de pagamento para acesso à algumas reportagens limitaram o levantamento de dados, o que significa dizer que esta amostra pode não representar a totalidade. Abaixo está o Quadro 2, com o número de reportagens por edição e a porcentagem equivalente. 
Quadro 2 - Número de reportagens por edição

\begin{tabular}{|l|l|l|}
\hline Edição & Número de reportagens & Porcentagem \\
\hline I edição dos JPI & 34 & $14,16 \%$ \\
\hline II edição dos JPI & 11 & $4,58 \%$ \\
\hline III edição dos JPI & 6 & $2,5 \%$ \\
\hline IV edição dos JPI & 25 & $10,41 \%$ \\
\hline V edição dos JPI & 4 & $1,66 \%$ \\
\hline VI edição dos JPI & 82 & $34,1 \%$ \\
\hline VII edição dos JPI & 9 & $3,75 \%$ \\
\hline VIII edição dos JPI & 2 & $0,83 \%$ \\
\hline IX edição dos JPI & 14 & $5,83 \%$ \\
\hline X edição dos JPI & 35 & $14,58 \%$ \\
\hline XI edição dos JPI & 12 & $5 \%$ \\
\hline XII edição dos JPI & 10 & $4,16 \%$ \\
\hline
\end{tabular}

Da I edição dos JPI, ocorrida em 1996, foram abordadas 34 reportagens. Destas, 3 reportagens falavam sobre Edson Arantes do Nascimento conhecido como Pelé, o então Ministro de Estado Extraordinário do Esporte na época. As reportagens restantes trataram sobre os jogos e a diversidade cultural dos JPI. Uma característica que foi observada em algumas reportagens é o teor político dos JPI. Principalmente na realização dos fóruns. Na edição do jornal "O Popular” de Goiás do dia 19 de outubro de 1996, diante das notícias do governo em extinguir a FUNAI, os indígenas se organizaram para aproveitar o espaço proporcionado pelos JPI para reivindicar seus direitos e chamar a atenção para as suas questões sociais como direito a terra, o alto índice de suicídios e a defesa da continuidade da FUNAI. Novamente é possível observar as nuances políticas presentes nos JPI, ao ser relatado a participação ativa da mulher por meio da entrevista de uma indígena. No relato, a mulher indígena comenta que não é submissa, que esta imagem é equivocada e formada, segundo ela, pelo homem branco.

Na II edição dos JPI ocorrida no Paraná, foi encontrado o Jornal de Londrina que realizou 11 reportagens entre os dias 30/09/1999 a 21/10/1999, o equivalente a 4,58\% do total da amostra. A cidade de Guaíra fica a $645 \mathrm{~km}$ da capital Curitiba, o jornal de Londrina, da cidade de Londrina fica a uma distância de aproximadamente $513 \mathrm{~km}$. A longa distância entre as cidades principais e a cidade anfitriã pode ser um fator que explique a baixa cobertura desta edição. Segundo dados do censo 2010, o IBGE aponta o estado do Paraná com 3,2\% do total 
da população autodeclarada indígena do país, este pode ser um outro fator que explique a baixa cobertura da imprensa nesta edição. Os temas principais e secundários abordaram basicamente as programações dos jogos, algumas modalidades e etnias. Ao contrário da primeira edição não foi observado pautas políticas. Contudo, é importante destacar que embora as reportagens não tenham retratado este tema, nos fóruns que aconteceram nos jogos foram tratados temas referentes à direitos indígenas.

A III edição ocorrida na ilha do Tucunaré, na cidade de Marabá-PA teve uma cobertura de seis reportagens. Os meios de comunicação que fizeram a cobertura foram: Os jornais O Liberal (Belém-PA), Notícia (Redenção-PA), O Independente (Conceição do Araguaia-PA) e a Agência Pará. Os temas abordaram poucos dias dos JPI, somente os dias 17 e 18. A maioria das matérias falaram sobre os JPI de uma forma geral, onde foi mostrado a programação e alguns jogos tradicionais. O tema secundário "Lideranças indígenas dos Estados Unidos e da Guatemala foram convidadas especiais do Fórum Social" chamou a atenção e reforçou o aspecto político dos JPI.

A IV edição foi sediada pela cidade de Campo Grande-MS e foram encontradas reportagens em seis jornais: Correio do Estado (Campo Grande), Primeira Hora (Campo Grande), Diário do Pantanal (Campo Grande), Folha do Povo (Campo Grande), O Progresso (Dourados /MS) e o Jornal Web RMI Online (Campo Grande). Esta edição teve a terceira maior quantidade de reportagens com 10,41\%. Os temas principais e secundários trouxeram informações gerais como a programação dos JPI. A reportagem do dia 21/10/2001 do jornal Correio do Estado teve como tema Marçal de Souza ${ }^{4}$, um dos indígenas mortos na luta pela terra, reforçou o fato dos JPI ter características políticas. ${ }^{5}$

Da V edição dos JPI ocorrida em Marapanin-PA entre os dias 14 a 21 de setembro de 2002, foram apuradas 5 reportagens, todas do jornal O Liberal (Belém-PA). Os temas principais e secundários trataram dos JPI de forma bem geral. Ao contrário desta edição, com 82 reportagens ou o equivalente a $34,16 \%$ a VI edição dos JPI sediada pela cidade de Palmas no Tocantins, representou a maior cobertura de todas as edições. Os preparativos e organização antes e durante dos JPI foram assuntos dos temas principais e secundários.

\footnotetext{
${ }^{4}$ Marçal de Souza foi um líder militante indígena guarani na década de 1970, foi um dos líderes precurssores pela recuperação e pelo reconhecimento de seus territórios ancestrais. Por lutar pelos direitos indígenas, principalmente pelos direitos indígenas ligados às terras, Marçal foi assassinado no dia 25 de novembro de 1983, no município de Antônio João, Mato Grosso do Sul

${ }^{5}$ SALES, O.S. Marçal de Souza: um índio militante marcado para morrer. In: SEMINÁRIO DE PESQUISA DA PÓS-GRADUAÇÃO EM HISTÓRIA, 6., 2013, Goiânia. Resumos... Goiânia: PUC-GO/UFG, 2013.
} 
Dentro dos temas, foram retratados alguns aspectos como a estrutura, a programação completa, a cultura, o envolvimento dos telespectadores com os JPI e as brincadeiras das crianças indígenas. As reportagens do jornal O Girassol dos dias 11 a 17/11/2003 "Dívida de colonizadores ainda não foi paga" e "Povos indígenas recuperando 500 anos" representaram o teor político dos JPI.

Da VII edição ocorrida em Porto Seguro-BA, foram coletadas 10 reportagens realizadas pelo jornal O Sollo (Porto Seguro-BA) com duas reportagens e da SETRAS (Informativo Mensal Secretaria do Trabalho e Ação Social da Bahia) com 8 reportagens. Os temas principais e secundários discorreram sobre os JPI de forma sucinta, nada específico. $\mathrm{O}$ teor político esteve presente na matéria que apresentou as cotas adotadas pela Universidade do Tocantins como conquista política dos JPI.

Foram encontradas apenas duas reportagens do jornal "Diário do Nordeste" a respeito dos VIII edição dos JPI realizada no estado do Ceará. Os dois temas principais foram: "Eventos Rituais marcam a abertura dos $8^{\circ}$ Jogos Indígenas" e "Jogos dos Povos Índios fazem festa nas águas do Rio Pacoti”. Como tema secundário foi realizado um relato sobre fogos e dança.

A IX edição foi sediada pelas cidades pernambucanas de Recife e Olinda. Foram coletadas 14 matérias de dois jornais, o jornal O Commercio (Recife) com 12 reportagens e o jornal O Liberal (Belém) com 2 reportagens. Os temas principais trataram de algumas modalidades como futebol, corrida de tora e arco e flecha. O teor político dos JPI, foi observado por meio da reportagem "Mudanças climáticas preocupam indígenas" do jornal O Liberal do dia 28/11/2007. Esta característica também estava presente no logo desta edição “Água é vida direito sagrado que não se vende".

A cidade de Paragominas no Pará sediou a X edição dos JPI. Os dados foram coletados da página do Ministério do Esporte, do jornal online da Bahia Nossacara, dos jornais Diário do Pará, O Globo, O Rebate, O Liberal (Belém), Jornal Local (Campinas), The Observer (Reino Unido), da revista Globo Rural e do jornal online UOL. Os temas principais trataram sobre a estrutura dos JPI, sobre a cultura e rituais de alguns povos.

Da XI edição foram coletadas 12 reportagens o equivalente a 5\% do total de matérias. Esta edição ocorreu em Porto Nacional, uma cidade que fica a $60 \mathrm{~km}$ da capital Palmas. A cobertura desta edição foi realizada pelas páginas online G1, Portal Terra e Portal Stylo (Tocantins/Palmas). Foram coletadas uma reportagem do jornal O Globo e uma reportagem do jornal Folha de São Paulo. Os temas principais e secundários abordaram principalmente a abertura dos jogos. Informações mais específicas foram realizadas pelos jornais locais. 
Embora não tenha sido retratado nos jornais, esta edição teve um forte apelo político relacionado ao meio ambiente. Segundo dados da página do Ministério do Esporte ${ }^{6}$, na época esta edição foi dividida em duas temáticas:

[...] uma relacionada ao Fórum Social Indígena e a Rio+20, abordará a Conferência Internacional do Meio Ambiente e discutirá a economia verde e temas com foco na sustentabilidade e na preservação das tradições indígenas. Já a segunda terá como objetivo o intercâmbio esportivo e cultural entre as etnias, além de propor um debate sobre a inclusão indígena como legado da Copa do Mundo FIFA 2014 e das Olimpíadas e Paraolimpíadas de 2016.

A XII edição dos JPI foi sediada pela cidade de Cuiabá capital do estado do Mato Grosso. Quatro jornais de Mato Grosso cobriram o evento com um total de 10 reportagens o equivalente a $4.16 \%$ do total de 240 matérias. Os temas principais abordaram basicamente a preparação e inauguração dos jogos.

$\mathrm{O}$ aspecto político foi uma característica comum a quase todas edições dos JPI o que parece concordar com os fóruns ocorridos nos eventos que abordavam questões como direitos indígenas à terra e à educação. Foi observado que não houve um aumento linear na cobertura dos JPI no decorrer das edições, como mostra o gráfico 2:

\footnotetext{
6 Acessível em <http://arquivo.esporte.gov.br/index.php/institucional/esporte-educacao-lazer-e-inclusao-
} social/jogos-indigenas/xi-edicao-porto-nacional-2011> 
Gráfico 1 - Número de reportagens por edição

№ de Reportagens por Edição

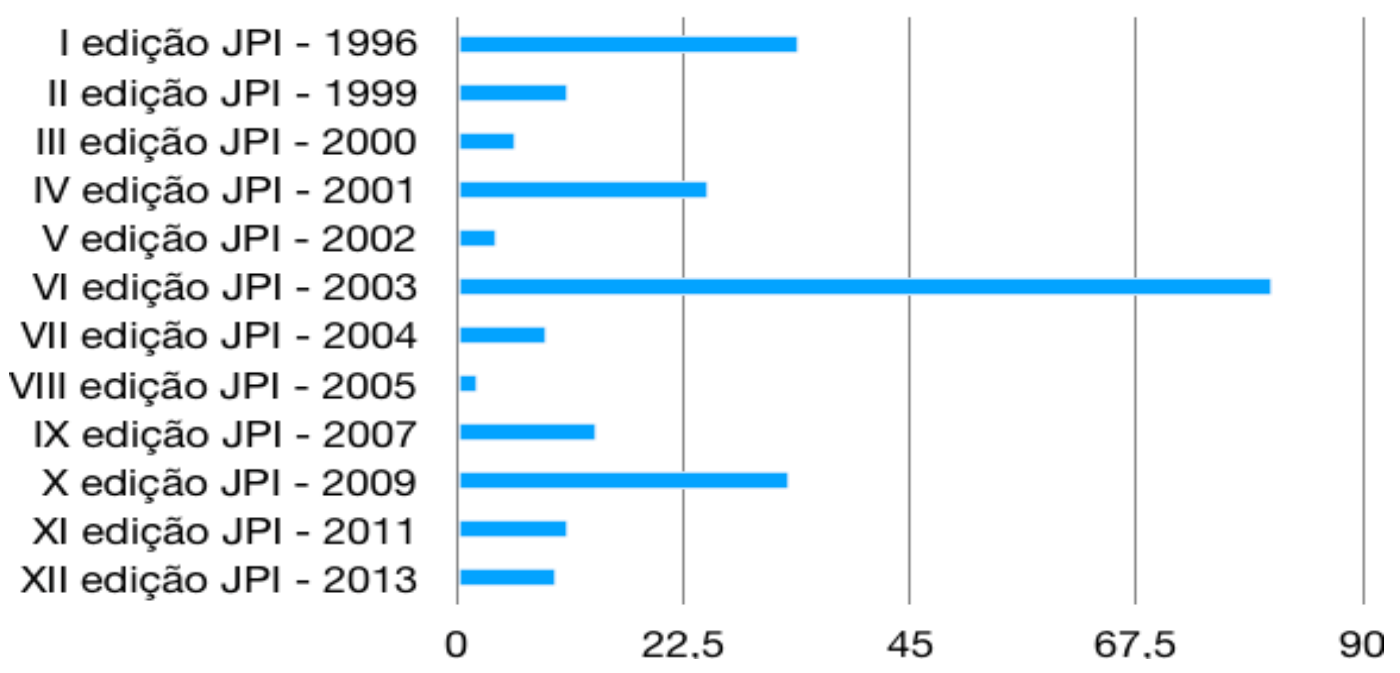

Este ponto, pode estar atrelado a alguns fatores, como por exemplo, políticas públicas realizadas no ano da edição, o governo vigente, uma vez que foi observado na análise das reportagens uma forte característica política dos JPI. Mas também, de acordo com Horne (2007) e Roche (2000), pode ser relacionado ao fato dos interesses por trás dos meios de comunicação, uma vez que os JPI são um evento não mega, talvez não atraia uma grande atenção como os Jogos Olímpicos. A falta de interesse da mídia em dar voz a estes grupos minoritários em detrimento a interesses políticos e econômicos de classes dominantes pode ter contribuído para a baixa cobertura da mídia em algumas edições.

Os JPI duram em média 7 dias e possuem programações para o dia inteiro. Além dos jogos, estão presentes atividades culturais, venda de artesanatos e a realização de oficinas, ou seja, possui um vasto campo para possíveis reportagens. Estas reportagens poderiam aprofundar especificidades e a cultura de algumas etnias, porém foi observado que a maioria das edições obtiveram uma baixa cobertura, no qual a mídia abordou as temáticas indígenas como algo exótico e primitivo.

Da I edição dos JPI as mídias que mais retrataram as modalidades e etnias foram os jornais O Popular (GO) e o Diário da Manhã (Goiânia), pertencentes à cidade anfitriã do evento. Esta edição teve a participação de 29 etnias e a apresentação de 9 modalidades. Estes jornais relataram todas as etnias participantes e as modalidades nas reportagens, contudo 
como estas informações pareciam não ser o foco das reportagens elas apenas foram citadas. $\mathrm{O}$ Jornal de Brasília comentou sobre algumas etnias participantes mas de forma superficial e falou resumidamente sobre o artesanato indígena presente no evento. As outras mídias citaram somente algumas etnias e modalidades. Esta edição teve uma reportagem do jornal internacional Arab Times (Estados Unidos), no qual foi relatado apenas as modalidades como a natação, o arco e flecha, o futebol e a corrida.

Foram encontradas apenas reportagens do jornal Folha de Londrina referentes à II edição dos JPI. Esta edição contou com a presença de 25 etnias e 7 modalidades. Apesar desta edição apresentar uma baixa cobertura as reportagens realizadas citaram todas as modalidades e etnias participantes. Com um total de 11 reportagens o Jornal de Londrina apresentou a programação do evento citando algumas etnias e ressaltando os sucesso na venda de artesanato.

Cerca de 900 indígenas de 39 etnias brasileiras participaram da III edição. As modalidades presentes nesta edição foram o arco e flecha, zarabatana, cabo de guerra, arremesso, canoagem, futebol e a natação. Contudo, esta edição apresentou uma baixa cobertura, as reportagens apenas citaram as etnias, não foi destacado nada específico e com relação às modalidades apenas algumas foram relatadas.

A IV edição contou com a participação de aproximadamente 850 indígenas de 40 etnias e teve 11 modalidades. Mesmo com a terceira maior quantidade de reportagens a IV edição dos JPI abordou as etnias de forma superficial, elas apenas foram citadas. Com relação as modalidades, todas foram relatadas e algumas matérias se aprofundaram e explicaram o funcionamento de algumas delas, como zarabatana e o arremesso de lança. Retratar especificidades culturais de algumas etnias e as modalidades presentes nos JPI nas reportagens, poderia contribuir para um melhor entendimento da população não indígena sobre a dinâmica dos JPI.

Com aproximadamente 1000 indígenas a V edição dos JPI apresentou 20 modalidades. Ao contrário da III edição também ocorrida no Pará, no qual teve a cobertura de 3 mídias pertencente à cidades paraenses, a cobertura desta edição foi realizada somente pelo jornal $\mathrm{O}$ Liberal (Belém/PA) no qual as etnias e modalidades apenas foram citadas. A V edição obteve uma reportagem a menos do que a III edição. Ambas edições tiveram uma baixa cobertura o que pode ter inviabilizado o espaço para explicações sobre as etnias e/ou o funcionamento das modalidades presentes.

A VI edição dos JPI contou com a reunião de mais de 1000 indígenas de 60 etnias diferentes. De todas as edições analisadas a VI edição dos JPI apresentou as etnias 
participantes e as modalidades presentes de forma mais completa, especialmente os jornais Folha do Tocantins, O Girassol (Palmas/TO) e o Jornal do Tocantins (Palmas/To) pertencentes à cidade anfitriã do evento. Algumas reportagens foram realizadas antes e depois do evento tratando assuntos referentes à características de algumas etnias e modalidades, o que pode ser um dos fatores para o grande sucesso de público presente nesta edição. Os jornais pertencentes às cidades mais distantes como a Folha de São Paulo não comentaram sobre as etnias e modalidades presentes nesta edição. O jornal Zero Hora (RS) comentou sobre as modalidades ronkrã, corrida de tronco e arco e flecha, mas não citou nenhuma etnia.

A VII edição dos JPI apresentou uma baixa cobertura, até mesmo dos jornais locais do evento. Foram encontradas reportagens apenas do jornal O Sollo (Porto Seguro) e do SETRAS (Informativo Mensal Secretaria do Trabalho e Ação Social da Bahia). Algumas reportagens citaram todas as etnias mas sem relatar especificidades. Estavam presentes nesta edição aproximadamente cerca de 1000 indígenas. Das 16 modalidades presentes nesta edição, foram citadas o arco e flecha, cabo de guerra, zarabatana e canoagem.

Com um dos maiores número de participantes a VIII edição dos JPI contou com a presença de aproximadamente 1300 indígenas de 31 etnias diferentes. No total estavam presentes 15 modalidades. Esta quantidade expressiva de participantes indígenas poderia fornecer a possibilidade para as mídias de tratar mais detalhadamente sobre as etnias e modalidades nas reportagens. Contudo, do total de 8 dias de evento foram encontradas apenas 2 reportagens de um jornal local, no qual apenas algumas etnias e modalidades foram citadas.

$\mathrm{Na}$ IX edição todas as etnias participantes foram citadas, contudo não foi ressaltada nenhuma característica específica. Das 18 modalidades presentes todas foram citadas e algumas explicadas. Foram encontradas 14 reportagens, das quais apenas 1 reportagem não era da cidade anfitriã. Embora esta edição tenha apresentado a quarta maior cobertura, pouco foi explorado sobre as etnias e/ou suas culturas. Uma das poucas modalidades abordadas foi o Takraw criado pelos povos indígenas da Malásia há mais de 500 anos. Segundo reportagem do jornal Commercio de PE do dia 30/11/2007, é um jogo semelhante ao voleibol que tem por objetivo de manter a bola no ar por mais tempo possível sem utilizar os braços ou as mãos.

Algumas reportagens da $\mathrm{X}$ edição citaram todas as etnias participantes e foi relatado as características de algumas delas. Algumas reportagens apenas citaram as modalidades. As reportagens que abordaram os temas de forma mais completa pertenciam à página online do Ministério do Esporte e da mídia pertencente ao Estado do Pará, anfitrião do evento. O jornal The Observer pertencente ao Reino Unido, citou as etnias Enawenê-nawê, Gavião e Ka'apor e todas as modalidades presentes, mas sem relatar especificidades de nenhuma delas. 
A mídia local da XI edição, ocorrida no Tocantins, foi responsável pela maior parte das reportagens. A mídia pertencente à cidade anfitriã realizou 8 reportagens que citaram as modalidades e etnias, porém sem ressaltar nenhuma característica delas. As outras mídias como o jornal O Globo e o portal de notícias Terra na internet apenas realizaram uma reportagem sem nenhum aprofundamento sobre as etnias e/ou modalidades.

As reportagens referentes à XII edição dos JPI foram todas realizadas pela mídia local do Mato Grosso. Das 48 etnias participantes desta edição, apenas a Kraô e Paresi foram citadas. Das 10 modalidades presentes nesta edição foram citadas as modalidades futebol, arco e flecha e o huka huka.

O que pode ser observado é que a maior parte das reportagens que aprofundaram algo sobre as etnias e /ou modalidades presentes nas edições pertenciam à mídia local do evento. Um fator que parece ter contribuído para o aprofundamento nas especificidades sobre etnias e/ou modalidades foi o tamanho da cobertura da mídia sobre o evento. Por exemplo, a VI edição dos JPI ocorrida no Tocantins teve o maior número de reportagens, principalmente da mídia local, o que proporcionou um maior espaço para explicações sobre as etnias e/ou modalidades presentes no evento.

A maior parte das mídias mais distantes do evento apenas citaram algumas etnias e/ou modalidades ou não citaram nenhuma delas. Contudo, apesar desta relação do aprofundamento sobre estes temas com a mídia local, não é possível afirmar que este seja um fator determinante no interesse da mídia no aprofundamento destas temáticas. Ao ser realizado um comparativo entre as VI e a XI edição dos JPI, ambas realizadas no Tocantins, isto fica bem nítido quando as poucas reportagens da XI edição apenas citaram as etnias e modalidades. O mesmo pode ser observado nas edições III e V realizadas no Pará, no qual além de uma baixa cobertura da mídia local também não realizaram detalhamento sobre estas temáticas.

A classificação dos meios de comunicação aqui levantados, podem estar atrelados aos relatos dos indígenas participantes e /ou organizadores dos JPI. Como aconteceu na reportagem da I edição dos JPI "Jogos indígenas são um sucesso" do jornal "O Estadão do Maranhão" do dia 19/10/1996, embora a repórter se refira aos JPI como programação esportiva, na reportagem é relatado pela autora a comemoração diferenciada realizada pelos indígenas Funi-ô no momento em que eles faziam gols. O relato de Marcos Terena sobre a profissionalização do futebol ainda estar muito longe das comunidades reforça o que foi 
descrito por Vinha (2004) sobre a interferência da mídia na conceituação dos JPI. A jornalista se refere aos JPI como uma comemoração aberta da multiculturalidade.

Na edição do dia 18/10/1996 do jornal O Popular, na reportagem "Goleadas marcam o início dos jogos indígenas" é possível observar uma mesma abordagem da cobertura de um evento competitivo, ao se usar termos como disputa, partidas, torneios. Contudo, no final da reportagem menções à um evento cultural ao final do dia, onde é ressaltado que os indígenas evocariam espíritos protetores, ressalta o teor diferenciado dos JPI.

A reportagem com o tema principal "Dia de índio" do jornal O Dia na data 21/10/1996 e com tema secundário "Uma lição de espírito olímpico nos Jogos dos Povos Indígenas" mostrava uma figura de um indígena e anéis das Olimpíadas embaixo. Esta matéria reforça a visão da imprensa como uma tentativa de igualar os JPI às Olimpíadas.

Foi possível observar na I edição que embora tenha sido constatado uma abordagem mais próxima sobre a classificação dos JPI, com relação à percepção em algumas partes das reportagens, foram apresentadas muitas expressões equivocadas, como "índios invadem Goiânia”. O verbo invadir, segundo dicionários da língua portuguesa, tem o significado de entrar violentamente em; conquistar, ocupar: invadir um país, ou seja, remete ao receptor da mensagem que os indígenas estão tomando algo que não é seu. A expressão invadir parece ser recorrente nas reportagens que tratam a respeito de temáticas indígenas como relatam os trabalhos de Costa e Santos (2015) e Batista, Silva e Simas (2015).

Na II edição dos JPI na classificação das matérias sobre os JPI foram usadas as expressões "competição" e "demonstração de modalidade esportiva", porém na maioria das matérias foi usada a expressão "jogos" para se referirem aos JPI. Com relação à percepção, alguns trechos foram problemáticos, como por exemplo, em uma das reportagens foi utilizado o termo primitivo para se referir à etnia Matis. Segundo Lima et al. (p. 220, 2016), ao ser usada a expressão "primitivo" o grupo referido seria desumanizado, ou seja:

[...] A desumanização decorre da criação de hierarquias entre os grupos, em que um se considera mais humano que outro. Nesse caso, um dos grupos se afirma possuidor de características especiais e, simultaneamente, nega ao outro a posse de tais atributos.

Na III edição dos JPI com relação à visão da imprensa, a maioria das matérias se referiram aos JPI como "jogos", mas também foram usadas expressões como "evento cultural", "evento esportivo" e "torneio". Na IV edição a maioria das reportagens usou “jogos” para se referirem aos JPI. Contudo é possível observar que a percepção da imprensa, na maior parte, apresentava uma leitura negativa de estereotipia. Vale ressaltar a análise de 
como esta construção pode interferir na abordagem da imprensa na hora da conceituar os JPI. Segundo Fleuri (2016, p. 497), estereótipo:

[...] indica um modelo rígido a partir do qual se interpreta o comportamento de um sujeito social, sem se considerar o seu contexto e a sua intencionalidade. $\mathrm{O}$ estereótipo representa uma imagem mental simplificadora de determinadas categorias sociais. Funciona como um padrão de significados utilizado por um grupo na qualificação do outro. Constitui imagens que cumprem o papel de criar ou acentuar a diversidade.

Das 24 reportagens, quatro se referiram apenas ao possível surto de catapora entre os indígenas e a vacinação deles. Contudo, o levantamento mostrou que a maioria das reportagens tratou os JPI como jogos. Esta classificação mais assertiva da mídia sobre os JPI pode estar atrelada ao fato destas reportagens pertencerem à mídia da cidade anfitriã. Isto ocorreria pela proximidade desta mídia aos JPI, ou seja, por ter um contato maior com os participantes e organizadores, passariam a ter uma noção mais real do que seriam os JPI.

A população indígena do Mato Grosso do Sul, segundo dados do IBGE, é a segunda maior do país. O levantamento deste dado é interessante para saber se a quantidade da população indígena da cidade iria interferir em uma abordagem mais assertiva da imprensa. $\mathrm{O}$ que pode ser constatado, pelo menos nesta edição, é que este fator pareceu não ter muita influência na maneira como a imprensa tratou os JPI.

$\mathrm{Na} \mathrm{V}$ edição dos JPI a imprensa classificou os JPI de 3 formas diferentes: "jogos", "competição" e "disputa esportiva". O termo "jogos" foi utilizado 4 vezes, já os termos "competição" e "disputa esportiva" foi utilizado apenas uma vez cada. Com relação à percepção, algumas expressões, analisadas durante as reportagens se referindo à alguns indígenas como "arredios", ou dizendo que eles "comem demais", depreciaram a imagem dos indígenas e dos JPI. Como relata Ximenes (2011), esta tendência de atribuir primitividade aos indígenas, supõe um atraso em relação à sociedade não indígena.

Para a análise da percepção, foi observada a distância de condução entre as cidades de Marapanim e Belém que é de aproximadamente $156 \mathrm{~km}$. A proximidade do evento poderia ser um ponto de relação interessante visto que o que se espera é que quanto mais próximo do evento mais a imprensa estaria envolvida no contexto dos JPI. Este é um ponto de relevância, uma vez que a imprensa possui a possibilidade de desempenhar um papel importante quando falamos em legado de participação, como exposto por Chalip et al. (2017). Quando Chalip et al. (2017) tratam da construção de uma imagem realista, eles falam em humanizar o atleta, de tirar aquela imagem de herói inalcançável. No contexto dos JPI esta relação da imagem 
realista que a imprensa deveria abordar está ligada à desconstrução de estereótipos. A imprensa ao abordar os JPI desta forma pode criar uma conexão verdadeira com os receptores da mensagem, sejam indígenas ou não e ao mesmo tempo possibilitar a contribuição para este possível legado de participação entre as comunidades indígenas.

As matérias referentes a VI edição apresentaram percepções positivas. Foi percebido uma dedicação e envolvimento maior no tratamento das reportagens, isto pode ter contribuído positivamente na cobertura do evento. Foi observado um amadurecimento por parte da imprensa na cobertura desta edição, tal fato pode ser relacionado a experiência adquirida no decorrer das quatro edições anteriores. Sobre a visão da imprensa ao classificar os JPI, a maior parte das reportagens relata os JPI como "jogos". Os outros termos usados foram: "festa esportiva", "competição", "apresentações esportivas e culturais" , "esportes indígenas" e "olimpíadas". É importante destacar que o maior interesse e a maior assertividade sobre as temáticas indígenas nesta edição pertenciam às mídias locais da cidade anfitriã.

A VII edição dos JPI apresentou uma das menores coberturas da mídia. Segundo dados do censo de 2010 do IBGE, a Bahia é o terceiro Estado com maior população indígena do país. Proporcionalmente ao número de habitantes o estado concentra as maiores taxas de pessoas que se auto declaram indígenas. Com 56.742 pessoas que se declaravam indígenas no ano de 2010 (6,9\% dos 821.501 indígenas brasileiros). Este dado vai ao encontro do que Pacheco e Munaro (2015) relatam sobre uma população indígena expressiva na cidade anfitriã não influenciar em um maior interesse da mídia em abordar temáticas indígenas. De um total de 9 reportagens apenas 2 pertencem a um jornal local. As matérias trataram os JPI apenas como “jogos”, não houve outra classificação. As percepções foram todas positivas.

A VIII edição também parece corroborar com o que os autores Pacheco e Munaro (2015) relatam, pois esta edição foi a que apresentou a menor cobertura da imprensa, mesmo o Ceará representando o $8^{\circ}$ Estado brasileiro com maior população indígena do país, com 26.071 aldeados. As duas reportagens realizadas sobre esta edição não apresentaram aprofundamento sobre nenhuma temática. A percepção sobre a mídia foi positiva e o JPI foram abordados como "jogos". Porém, a falta de aprofundamento e uma quantidade de matérias reduzidas podem comprometer a análise sobre a percepção que a mídia possui com relação aos JPI, ou seja, se ela aborda as temáticas indígenas de forma estereotipada ou não. $\mathrm{O}$ mesmo pode ocorrer com relação à visão destas mídias sobre os JPI. Contudo, a quantidade reduzida de matérias e este não aprofundamento sobre os JPI possui a possibilidade de se caracterizar como uma mídia local pouco interessada nas temáticas indígenas.

Com um total de 14 reportagens a IX edição teve uma cobertura local de 12 matérias. 
As outras duas reportagens foram realizadas pelo jornal $\mathrm{O}$ Liberal pertencente à cidade anfitriã Palmas possuidora da maior cobertura da mídia de todas as edições analisadas. É válido ressaltar que a maior parte das matérias sobre os JPI foram realizadas pelas mídias das cidades anfitriãs dos JPI. Nesta edição a visão da imprensa abordou os JPI como "jogos". As outras referências trataram os JPI como "disputa" e "Olimpíadas indígenas". A percepção sobre a abordagem da imprensa nesta edição foi toda positiva.

Da X edição dos JPI foram contabilizadas 35 reportagens, a maioria abordou os JPI como "jogos". Foram usadas também expressões como "competição indígena", "evento esportivo e cultural da tradição indígena", "Olimpíada", "competição esportiva" e "competição". A utilização do termo "Olimpíada Verde", foi usada pela primeira vez e reforçou a característica política dos JPI. O termo "Olimpíada Verde" permite inferir que o fator político influenciou a visão da mídia e a percepção, que nesta edição foram todas positivas. Segundo algumas reportagens, os JPI receberam este nome devido ao fato de Paragominas ter passado, na época, de condição de cidade que mais desmatava para a que mais reflorestava no estado do Pará. Este fato foi bem divulgado pela imprensa que cobriu os JPI e decorreu, segundo as reportagens, por uma iniciativa da prefeitura de Paragominas e teve como resultado a plantação de mais de 50 milhões de árvores nativas.

O Estado do Tocantins sediou pela segunda vez os JPI, a XI edição ocorreu na cidade de Porto Nacional. Com 12 reportagens esta edição apresentou uma menor cobertura da mídia quando comparada à VI edição. A mídia se referiu aos JPI como "encontro esportivo cultural e tradicional de indígenas da América", "evento" e "competição", porém a maioria das reportagens usou o termo “jogos”. Com relação à percepção todas foram positivas.

As reportagens referentes à XII edição se referiram aos JPI como “jogos” havendo só uma referência aos JPI como "manifestações esportivas". A percepção ds reportagens foram todas positivas. Como base no total das reportagens apuradas, as matérias abordaram os JPI com classificações mais próximas do conceito de Fassheber (2006). A maioria se referiu aos JPI como "jogos”, em segundo lugar as matérias usaram a classificação "evento competitivo", em terceiro usaram a classificação "evento" e em quarto a classificação "esportes". Como mostra abaixo o gráfico 1 : 
Gráfico 2 - Frequência das conceituações dos JPI realizadas nas reportagens

Total

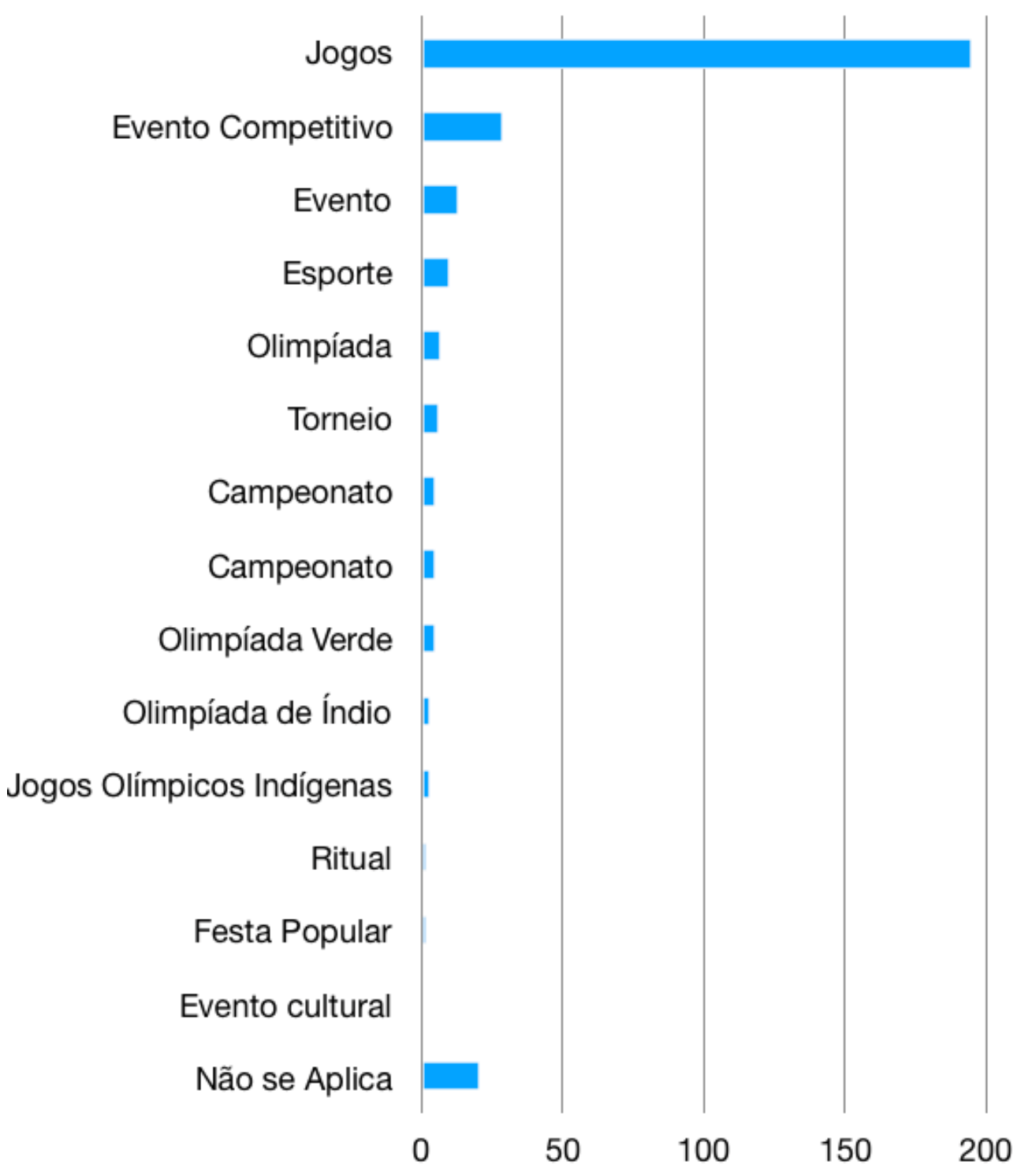

Embora, a maioria das reportagens tenham se referido aos JPI como "jogos", dentro do contexto das reportagens esta terminologia estava atrelada muitas vezes à concepção de esporte padronizado. Embora a classificação "jogo" usada na maioria das reportagens, aqui considerada como a classificação mais próxima do conceito de Fassheber (2006), ela não pode ser analisada isoladamente, ou seja, fora do contexto das matérias. Isto porque a maioria dos conteúdos possuíam uma conotação diferente de jogo, uma visão de "Jogos dos brancos" expressão usada por Gruppi (2013) ao relatar os diferentes tipos de objetivos. 
Na entrevista de Carlos Terena para Gruppi (2013, p. 93), é possível refletir sobre esta abordagem por conta da imprensa:

\begin{abstract}
(...) digamos assim, agora nós não incentivamos um atleta Carajá ou Xavante brigar entre si por causa de uma medalha porque isso não é importante pra gente..., porque o espírito de competição, ele ta no meio do branco ele não ta no meio dos indígenas, então que o índio não quer ganhar não que cada atleta quer ganhar... se você for numa aldeia por exemplo você não vai ver o campeão de Uca Uca você não vai ver o campeão de corrida de tora, todos tem os seus valores, dentro de uma comunidade então a gente não incentiva essas coisas nos jogos..., nós fizemos nós incentivamos isso, tudo tem o contexto espiritual dentro dos jogos, tem o contexto das nossas danças, tem o contexto das nossas cerâmicas, das nossas comidas, e depois tem o contexto dos Jogos propriamente dito, e do contexto social também, porque a gente tem o lado educativo dos jogos, tanto para os indígenas como para os jovens branco por exemplo, a gente busca ensinar um pouco a maneira mais correta de não sujar o rio por exemplo... tanto quando quem ganhar a gente fala que o importante pra nós é a gente brincar entre nós, celebrar, vamos celebrar a vida, celebrar a comida, celebrar a natureza, celebrar Deus nosso criador, celebrar a vida de uma maneira geral, então a gente tenta passar isso pros nossos parentes e muito deles entendem isso (TERENA, 2009).
\end{abstract}

Expressões usadas por participantes e coordenadores dos JPI observadas em algumas reportagens como esporte, competição e treinamentos nas aldeias, é explicado por Vinha (2004) como um fenômeno resultante de interferências da mídia e políticas públicas que reforçam esta configuração. Deste ponto específico, é possível dizer, como relata Fassheber (2006) que ocorreu um duplo mimético, onde a imprensa tentou classificar os JPI a partir das suas construções e por um outro lado está a leitura dos participantes e organizadores ao se referirem aos JPI.

Foi observado que as percepções estereotipadas interferiram diretamente na visão dos JPI durante as reportagens. Apesar de representar um percentual pequeno, não é possível generalizar este resultado, pois como mostram alguns trabalhos do meio acadêmico, a imprensa possui um despreparo em abordar temáticas indígenas, como alguns exemplos relatados acima, pareceu haver uma tendência de tratá-los como primitivos, outro fato é a questão da imprensa muitas vezes ser parcial (COSTA; SANTOS, 2015; ARAÚJO, 2016; FREIRE, 2019b). Outro ponto, passível de reflexão, é o fato destes ocorridos terem acontecido nas primeiras edições, embora não seja possível afirmar que a imprensa tenha amadurecido estas questões no decorrer das edições. Porém, é viável dizer que os meios de comunicação têm grande importância na divulgação dos JPI, que a sua abordagem pode influenciar diretamente a visão e a precepção dos JPI.

$\mathrm{Na}$ análise total, a visão dos jornais pertencentes às cidades anfitriãs foi mais próxima 
da classificação dos JPI. A primeira edição pareceu confirmar este fator, no qual a Folha de São Paulo classificou os JPI como Olimpíadas e a revista Isto É usou a classificação versão tupiniquim das olimpíadas. No entanto, algumas edições apresentaram uma baixa cobertura da imprensa, com matérias que não aprofundaram sobre as temáticas dos JPI. Como foi abordado anteriormente, eventos desta natureza devem ser entendidos e classificados, com intuito de haver planejamento para alavancagem de possíveis legados de participação, como relatam Reis, de Sousa-Mast e Gurgel (2013). 
Ao classificar e entender os Jogos dos Povos Indígenas pelo olhar da gestão esportiva, foi possível compreender, que devido as suas características únicas e a sua classificação como evento não mega, os JPI tem um grande potencial em trazer benefícios para os seus envolvidos, especialmente quando se fala sobre legado de participação. Para que isto ocorra uma melhor gestão dos JPI será necessária. Os relatos de mídia usados como fonte de informação nesta pesquisa mostram que os gestores dos jogos ainda precisam promovê-los de maneira muito mais eficaz para criar efeitos positivos para os seus beneficiários principais, os próprios povos indígenas.

Considero que para a compreensão dos possíveis legados de participação advindos dos Jogos dos Povos Indígenas é necessário o entendimento sobre as práticas corporais e seus significados de cada etnia. Os gestores dos JPI têm a missão de informar a imprensa sobre isto. Com suporte de Viveiro de Castro (1979) e Mauss (2003), foi concebida a ideia diferenciada de corpo indígena, entendimento imprescindível para o desvencilhamento da concepção de que os JPI se encaixariam em uma classificação reducionista de eventos esportivos. Ao mesmo passo a necessidade da compreensão de práticas corporais, como sugerido por autores como Vinha (2004), Gruppi (2013) e Ferreira e Vinha (2015).

Esta construção permitiu vislumbrar a classificação dos JPI com um olhar ainda mais diferenciado, compreendendo-o como etno-desporto. Onde os JPI são reconhecidos como processos dinâmicos, como relatado por Fassheber (2006), no qual as práticas tradicionais indígenas e a introdução dos esportes modernos seriam como diz Vinha (2004) ressignificados e/ou significados. Uma divulgação mais apropriada do termo etno-desporto pode informar a mídia e melhorar a qualidades dos relatos sobre os JPI.

Nesta acepção, não faria sentido realizar estas reflexões sem entender como "as janelas interpretativas do mundo contemporâneo" (expressão usada por Barreira (2020) ao se referir à mídia) abordam os JPI. A análise da cobertura da mídia sobre os JPI, permitiu realizar algumas suposições. A primeira delas é que a mídia, quando aborda os JPI, apresenta o mesmo comportamento ao abordar temáticas indígenas de uma forma geral. Geralmente pautadas em construções estereotipadas, sensacionalistas ou simplesmente com o intuído de expressar os interesses das classes dominantes, como relatado por Melo (2008).

Outro apontamento, a partir das análises, é que a mídia além de se apresentar muitas vezes despreparada para tratar dos JPI, ou seja, não conseguir apresentar classificações 
adequadas ainda demonstra falta de interesse em tratar dos JPI, fato observado pelo número de reportagens levantadas em algumas edições como a II, V e VIII edições. Tal ponto é confirmado também pela falta de aprofundamento nas reportagens, como relata Melo (2008, p. 8):

\footnotetext{
E em grande parte das reportagens, apenas o nome "índio" é referido, sem qualquer aprofundamento ou aproximação da reportagem à realidade indígena brasileira ou regional, bastante diversa em virtude das variantes culturais de cada região onde há comunidades indígenas.
}

Embora as reportagens tratassem os JPI como "jogos" na maioria das vezes, no contexto das reportagens esta classificação estava mais ligada a um conceito de esporte padronizado distante dos significados que os JPI possuem.

A percepção estereotipada sobre os indígenas e os JPI que a mídia apresentou não impediu o tratamento da mídia com relação aos JPI como "jogos", embora já tenha sido explicado o contexto que a expressão "jogos" foi usada. Este fato pode ser observado principalmente nos jornais das cidades anfitriãs dos JPI. Por outro lado, em algumas reportagens onde a percepção foi considerada estereotipada, geralmente em mídias que estavam longe dos JPI, tanto em um distanciamento físico e cultural, afetou diretamente a classificação dos JPI, como no caso da revista Isto É, que se referiu aos JPI como "Versão Tupiniquim das Olimpíadas".

Como foi observado sobre a expressividade da população indígena das cidades anfitriãs não ser pressuposto para uma abordagem da mídia menos esterotipada, isto não significa dizer que não exista engajamento e representatividade destes grupos. Mas sim que a mídia, apesar de possuir um papel social, como diz Ijuim (2009), apresenta uma abordagem estereotipada, construída historicamente e enraizada nas arcaicas concepções de colonizador e colonizado.

Considero que os JPI são um evento não mega com características únicas, um evento genuinamente brasileiro com o potencial de gerar legados tangíveis e outros intangíveis, em especial o legado de participação social considerado relevante para comunidades como as indígenas. Dentro do contexto da história passada e atual do povo indígena, o legado de participação como resultado dos JPI é talvez um caminho para resgatar e perpetuar a cultura destes povos.

Considero ainda que a análise da abordagem da mídia sobre os JPI possibilitou a compreensão da forma como os meios de comunicação classificam e enxergam os JPI, além de aumentar a sensação de responsabilidade de maiores investigações e envolvimento da 
gestão esportiva sobre este evento e com a própria mídia. Esta análise permitiu o entendimento que a cobertura de eventos desta natureza ainda apresenta uma visão bastante estereotipada, tanto com relação à sua abordagem na classificação dos JPI quanto à sua postura preconceituosa com relação ao tratamento de temáticas indígenas.

Nitidamente esta evolução está ligada a fatores sociais mais complexos. Como solução, é possível realizar uma analogia baseada na formulação de Freire (2019b), no qual o autor realiza uma reflexão sobre o conhecimento acerca dos terremotos não ser capaz de eliminá-los mas de nos permitir sobreviver a eles. Isto significa dizer que talvez não seja possível eliminar as percepções negativas da mídia com relação às temáticas indígenas e aos JPI mas ao conhecer este evento podemos diminuir os danos de estereótipos historicamente construídos. Assim, ao reconhecer que esta evolução da mídia seja talvez um processo complexo e longo, o conhecimento sobre os JPI, seus legados e classificação pode tornar seus gestores, segundo Freire (2019b), capazes de intervir na realidade.

Esta pesquisa apresenta algumas limitações. A escolha dos documentos foi realizada mediante a uma pesquisa exploratória a qual os meios de comunicação e fontes utilizadas foram jornais, revistas, arquivos e internet. Informações e documentações também foram consultadas do Comitê Intertribal - Memória e Ciência Indígena e Memorial dos Povos Indígenas e do projeto intitulado "Jogo, Celebração, memória e Identidade: Reconstrução da trajetória de criação, implementação e difusão dos Jogos Indígenas no Brasil (1996 - 2009)”.

Mesmo com a convicção que as fontes consultadas são possuidoras de um acervo riquíssimo e completo, pode ter sido perdida alguma informação sobre o que foi publicado na mídia a respeito dos JPI. Entrei em contato com a edição de alguns meios de comunicação por telefone ou via e-mail. Alguns meios de comunicação cobram o pagamento de taxas para o acesso de algumas reportagens, o que limitou o levantamento de dados. Foram utilizadas apenas as informações com acesso gratuito em jornais, revistas e internet.

Para pesquisas futuras relacionadas as temáticas indígenas, sugiro o envolvimento prévio com propósitos da natureza do projeto “Jogo, Celebração, memória e Identidade: Reconstrução da trajetória de criação, implementação e difusão dos Jogos Indígenas no Brasil (1996 - 2009)" e/ou envolvimento com as próprias comunidades indígenas que se objetivam ter como sujeitos de pesquisa. 
AGHA, N.; TAKS, M.A. A theoretical comparison of the economic impact of large and small events. International Journal of Sport Finance, Morgantown, v. 10, n. 3, p. 199-216, 2015.

ALBUQUERQUE JÚNIOR, D.M. Xenofobia: medo e rejeição ao estrangeiro. São Paulo: Cortez, 2016. 192 p.

ALMEIDA, A.J.M. Esporte e cultura: análise acerca da esportivização de práticas corporais nos Jogos dos Povos Indígenas. 2008. 131 f. Dissertação (Mestrado em Educação Física) Faculdade de Educação Física, Universidade de Brasília, Brasília, 2008.

ALMEIDA A.J.M.; ALMEIDA, D.M.F.; GRANDO, S.B. As práticas corporais e a educação do corpo indígena: a contribuição do esporte nos Jogos dos Povos Indígenas. Revista Brasileira de Ciência e Esporte, Brasília, v. 32, n. 2, p. 59-74, 2010.

ARAÚJO, R.B. Imprensa e História: a crise do SPI e a violação dos direitos indígenas narradas pelo Jornal do Brasil (1966-1968). In: ENCONTRO DE HISTÓRIO, 17., 2006, Rio de Janeiro. Anais... Rio de Janeiro: ANPUH-RJ, 2006.

BAINES, S. G. In: SMILJANIC, M. I.; PIMENTA, J. Faces da Indianidade. In: SMILJANIC, M. I; PIMENTA, J.; BAINES, S. G.Smiljanic

BARDIN, L. Análise de conteúdo. Lisboa: LDA, 1977.

BATISTA, D.N.; SILVA, L.W.A.; SIMAS, H.C.P. O outro lado do índio: representações sociais na mídia. Revista Eletrônica Mutações, Manaus, v. 6, n. 11, p. 141-151, 2015.

BRENT RITCHIE, J.R. Assessing the impact of hallmark events: conceptual and research issues. Journal of Travel Research, Thousand Oaks, v. 23, n. 1, p. 2-11, 1984.

BRONSTEIN, L. A crise do urbanismo contextualista. Revista de Pós-Graduação de Arquitetura e Urbanismo da FAUUSP, São Paulo, v. 19, n. 32, p. 158-177, 2012.

BARREIRA, B.B. Produtos midiáticos e representações sociais. Observatório da Imprensa, 2020. Disponível em: <http://observatoriodaimprensa.com.br/e-noticias/produtos-midiaticose-representacoes-sociais/>. Acesso em: 6 jan. 2020.

BUITRAGO, E.A.C. naĩ ãweẽ i nucuma' ü : Jogos autóctones ticunas na perspectiva dos povos indígenas da Região Amazônica Colombiana. 2013. 122 f. Dissertação (Mestrado em Ciência do Movimento Humano) - Escola de Educação Física, Universidade Federal do Rio Grande do Sul, Porto Alegre, 2013.

CAMARGO, V. R. T. et al. Mídia e divulgação científica e instrumentos para a preservação das culturas: um olhar sobre os jogos interculturais dos povos indígenas. Revista Eletrônica CEDOC/SEME, São Paulo, v. 1, 2010. Número Especial.

CARDOSO, A.; MATTOS, I; KOIFMAN, R. Prevalência de fatores de risco para doenças cardiovasculares na população Guaraní-Mbyá do Estado do Rio de Janeiro. Cadernos de Saúde Pública, Rio de Janeiro, v. 17, n.2, p. 345-354, 2001. 
COSTA, S.L.M.; SANTOS, M.R.S. A cobertura jornalística do índio de Alagoas na imprensa local. In: CONGRESSO BRASILEIRO DE CIÊNCIAS DA COMUNICAÇÃO, 38., 2015, Rio de Janeiro. Resumos... Rio de Janeiro: Intercom - Sociedade Brasileira de Estudos Interdisciplinares da Comunicação, 2015.

COMITÊ INTERTRIBAL. Memória e Ciência Indígena e Memorial dos Povos Indígenas. Disponível em: <www.labjor.unicamp.br/indio/>. Acesso em: 15 out. 2019.

CHALIP, L. et al. Creating sport participation from sport events: making it happen. International Journal of Sport Policy and Politics, Manchester, v. 9, n. 2, p. 257-276, 2017.

DA COSTA, L.P.; MIRAGAYA, A. Estado da arte do conhecimento sobre legados de megaeventos esportivos no exterior e no Brasil. In: DA COSTA, L.P. et al. (Eds.). Legados de megaeventos esportivos. Brasília: Ministério do Esporte, 2008. p. 33-45.

D’ARAÚJO, M.C. Capital social. Rio de Janeiro: Jorge Zahar. 2003.

DJABALLAH, M.; DESBORDES, M.; HAUTBOIS, C. Non-mega sporting events social impacts: a sensemaking approach of local governments' perceptions and strategies. European Sport Management Quarterly, Loughborough, v. 15, n. 1, p. 48-76, 2015.

ELIAS, N.; DUNNING, E. A busca da excitação. Lisboa: Difel, 1992.

FASSHEBER, J.R.M. Contribuições da antropologia social a partir da experiência entre os Kaiang. 2006. 170 f. Tese (Doutorado em Educação Física) - Universidade Estadual de Campinas, Campinas, 2006.

FERREIRA, M.B.R.; VINHA, M. Celebrando os jogos, a memória e a identidade: XI Jogos dos Povos Indígenas. Porto Nacional - Tocantins, 2011. Dourados: UFGD, 2015. 272 p.

FERREIRA M.E.V.; MATSUO T.; SOUZA, R.K.T. Aspectos demográficos e mortalidade de populações indígenas do Estado do Mato Grosso do Sul, Brasil. Caderno de Saúde Pública, Rio de Janeiro, v. 27, n. 12, p. 2327-2339, 2011.

FLEURI, R.M. Políticas da diferença: para além dos estereótipos na prática educacional. Educação \& Sociedade, Campinas, v. 27, n. 95, p. 495-520, 2006.

FREIRE, M.J.A. A construção de um réu: Payakã e os índios na imprensa brasileira. Rio Grande do Norte: EDUFRN, 2019a.

FREIRE, P. Pedagogia da autonomia saberes necessaries à prática educativa. 61. ed. São Paulo/Rio de Janeiro: Paz e Terra, 2019b. 144 p.

GETZ, D. Event tourism: definition, evolution, and research. Tourism Management, Guildford, v. 29, n. 3, p. 403-428, 2008.

GIBSON, H.J.; KAPLANIDOU, K.; KANG, S.J. Small-scale event sport tourism: a case study in sustainable tourism. Sport Management Review, Brisbane, v. 15, n. 2, p. 160-170, 2012.

GIRGINOV, V.; HILLS, L. A sustainable sports legacy: creating a link between the London 
Olympics and sports participation. The International Journal of the History of Sport, State College, v. 25, n. 14, p. 2091-2116, 2008.

GOMES, M. Jogos Indígenas em pauta o índio tratado na imprensa brasileira. In: CAMARGO, V.R.T.; ROCHA FERREIRA, M.B.R; von SIMSON, O.R. (Orgs.). Jogo, celebração, memória e identidade: reconstrução da trajetória de criação, implementação e difusão dos Jogos Indígenas no Brasil (1996-2009). Campinas: Curt Nimuendajú, 2011.

GRANDO, B.S. Jogos e culturas indígenas: possibilidades para a educação intercultural na escola. Cuiabá: Editora UFMT, 2010.

GRATTON, C.; DOBSON, N.; SHIBLI, S. The economic importance of major sports events: a case-study of six events. Managing Lisure, Abingdon, v. 5, n. 1, p. 17-28, 2000.

GUIZZO, B.S.; KRZIMINSKI, C.O.; OLIVEIRA, D.L.L.C. O Software QSR NVIVO 2.0 na análise qualitativa de dados: ferramenta para a pesquisa em ciências humanas e da saúde. Revista Gaúcha Enfermagem, Porto Alegre, v. 24, n. 1, p. 53-60, 2003.

GUTTMAN, A. Visando a modernidade arco e flecha e a modernização do Japão. Movimento, Porto Alegre, v. 10, n. 3, p. 9-21, 2004.

GRUPPI, D.R. Jogos dos povos indígenas: trajetória e interlocuções. 2013. 163 f. Tese (Doutorado em Educação Física) -Faculdade de Educação Física, Universidade Estadual de Campinas, Campinas, 2013.

HARVEY, J. The role of sport and recreation policy in fostering citizenship: the canadian experience. Canadian Policy Research Networks, Ottawa, Discussion Paper, p. 23-45, 2001.

HORNE, J. The four 'knowns' of sports mega events. Leisure Studies, London, v. 26, n. 1, p. 81-96, 2007.

HORNE, J.; MANZENREITER, W. An introduction to the sociology of sports mega-events. The Sociological Review, London, v. 54, n. s2, p. 1-24, 2006.

IJUIM, J.K. A responsabilidade social do jornalista e o pensamento de Paulo Freire. Em Questão, Porto Alegre, v. 15, n. 2, p. 31-43, 2009.

IBGE - Instituto Brasileiro de Geografia e Estatística. Os indígenas no Censo Demográfico 2010 - Primeiras considerações com base no quesito cor ou raça. In: IBGE. Censo Demográfico 2010. Rio de Janeiro, 2010.

KLEIN, O.J. A midiatização do telejornalismo em rede: as reportagens da Rede Brasil Sul de Televisão sobre os indígenas caingangues no Rio Grande do Sul. 2008. 264 f. Dissertação (Mestrado em Ciências da Comunicação) - Universidade do Vale do Rio dos Sinos, São Leopoldo, 2008.

LAZZAROTTI FILHO, A. et al. O termo práticas corporais na literatura científica brasileira e sua repercussão no campo da Educação Física. Movimento, Porto Alegre, v. 16, n. 1, p. 1129, 2010.

LIMA, T.S. O que é um corpo? Religião e Sociedade, Seropédica, v. 22, n. 1, p. 9-20, 2002. 
LIMA M.E.O.; FARO A.; SANTOS, M.R. A desumanização presente nos estereótipos de índios e ciganos. Psicologia: Teoria e Pesquisa, Brasília, v. 32, n. 1, p. 219-228, 2016.

MALUF, S.W. Corpo e corporalidade nas culturas contemporâneas: abordagens antropológicas. Esboços: Revista do PPG História da UFSC, Florianópolis, v. 9, n. 9, p. 87$101,2001$.

MARRIS, T. The role and impact of mega-events and attractions on regional and national tourism development resolutions. The Tourist Review, San Francisco, v. 42, n. 4, p. 3-12, 1987.

MAUSS, M. As técnicas do corpo. In: MAUSS, M. Sociologia e Antropologia. São Paulo: Cosac Naify, 2003, p. 399-422.

MELO, P.B. O índio na mídia: discurso e representação social. Fundação Joaquim Nabuco, Observa Nordeste textos especiais, 2008. Disponível em: <http://www.fundaj.gov.br/geral/observanordeste/indi o.pdf>. Acesso em: $1^{\mathrm{o}}$ jun. 2018.

MÜLLER, M. What makes an event a mega-event? Definitions and sizes. Leisure Studies, London, v. 34, n. 6, p. 627-642, 2015.

OLIVEIRA, C.S.; LOTUFO NETO, F. Suicídio entre povos indígenas: um panorama estatístico brasileiro. Revista Psiquiatra Clínica, São Paulo, v. 30, p. 1, p. 4-10, 2003.

PACHECO, R.P.M.; MUNARO, L.F. O indígena em Roraima: representações invisíveis. In: CONGRESSO BRASILEIRO DE CIÊNCIAS DA COMUNICAÇÃO, 38., 2015, Rio de Janeiro. Resumos... Rio de Janeiro: Sociedade Brasileira de Estudos Interdisciplinares da Comunicação, 2015.

PINTO, L.M.S. Legados dos Jogos dos Povos Indígenas. In: FERREIRA, M.B.R.; VINHA, M. Celebrando os jogos, a memória e a identidade: XI Jogos dos Povos Indígenas. Porto Nacional - Tocantis, 2011. Dourados: UFGD, 2015. 272 p.

PINTO, L.M.S.; GRANDO, B. S (Orgs.). Brincar, jogar, viver: IX Jogos dos povos indígenas. 2. ed. Brasília: Editora Ideal, 2011.

POIT, D.R. Organização de eventos esportivos. 4. ed. São Paulo: Phorte, 2006.

PORTES, A. Capital social: origens e aplicações na sociologia contemporânea. Sociologia, Problemas e Práticas, Oeiras, n. 33, p. 133-158, 2000.

POTWARKA, L.R.; LEATHERDALE, S.T. The Vancouver 2010 Olympics and leisure-time physical activity rates among youth in Canada: any evidence of a trickle-down effect? Leisure Studies, London, v. 35, n. 2, p. 241-257, 2016.

PREUSS, H. The conceptualisation and measurement of mega sport event legacies. Journal of Sport Tourism, Malmö, v. 12, n. 3-4, p. 207-228, 2007.

REIS, A.C.; DE SOUSA-MAST, F.R.; GURGEL, L.A. Rio 2016 and the sport participation legacies. Leisure Studies, London, v. 33, n. 5, p. 437-453, 2013. 
RAMCHANDANI, G. et al. Limited or lasting legacy? The effect of non-mega sport event attendance on participation. European Sport Management Quartely, Loughborough, v. 15, n. 1, p. 93-110, 2015.

ROCHA, C.M. Rio 2016 Olympic Games and diplomatic legacies. Internacional Journal of Sport Policy and Politics, Manchester, v. 9, n. 2, p. 1-18, 2017.

ROCHA, C.M.; BARBANTI, V.J.; CHELLADURAI, P. Support of local residents for the 2016 Olympic Games. International Journal of Event Management Research, Queensland, v. 21, n. 2, p. 20-41, 2016.

ROCHA FERREIRA, M.B. et al. Cultura corporal indígena. In.: COSTA, L.P. (Org.). Atlas do esporte no Brasil. Rio de Janeiro: Shape Editora e Promoções Ltda, 2005. p. 35-36.

ROCHE, M. Mega-events and modernity: olympics and expos in the growth of global culture. London: Routledge, 2000. 281 p.

RUHANEN, L.; WHITFORD, M. Indigenous sporting events: more than just a game. International Journal of Event Management Research, Queensland, v. 6, n. 1, p. 33-51, 2011.

SALES, O.S. Marçal de Souza: um índio militante marcado para morrer. In: SEMINÁRIO DE PESQUISA DA PÓS-GRADUAÇÃO EM HISTÓRIA, 6., 2013, Goiânia. Resumos... Goiânia: PUC-GO/UFG, 2013.

SANTIN, S. Esporte: identidade cultural. In: SOUZA E SILVA, J.E.F. (Org.). Esporte com identidade cultural. Brasília: Instituto Nacional de Desenvolvimento do Desporto, 1996. p. 13- 25. Série: Esportes de Criação Nacional.

SANTOVITO, T.C. A Copa do Mundo 2006: megaevento esportivo como atração turística, instrumento de comunicação e interação entre os povos. Comunicação \& Inovação, São Caetano do Sul, v. 7, n. 13, p. 50-58, 2006.

SOUZA, L.S.; PAPOUS, S. Legados esportivos de megaeventos esportivos: uma revisão da literatura. Motrivivência, Aracajú, v. 25, n. 41, p. 42-56, 2013.

TAKS, M. Social sustainability of non-mega sport. European Journal for Sport and Society, Copenhague, v. 10, n. 2, p. 121-141, 2013.

TAKS, M.; CHALIP, L.; GREEN, B.C. Impacts and strategic outcomes from non-mega sport events for local communities. European Sport Management Quarterly, Loughborough, v. 15, n. 1, p. 1-6, 2015.

TAVARES, O. Megaeventos esportivos. Movimento, Porto Alegre, v. 17, n. 3, p.11-35, 2011.

TERENA, C.J. Depoimento [ago. 2009]. Entrevistadora: Diana Vicente Ruiz - LABJORUNICAMP, Entrevista concedida ao LABJOR/UNICAMP, Campinas, SP.

TROVATO, F. Aboriginal mortality in Canada, the United States and New Zealand. Journal of Biosocial Science, Oxford, v. 33, n. 1, p. 67-86, 2001. 
VIANNA, F.F.L.B. A bola, os "brancos" e as toras: futebol para índios xavantes. 2001. 459 f. Dissertação (Mestrado em Antropologia Social) - Faculdade de Filosofia, Letras e Ciências Humanas, Universidade de São Paulo, São Paulo, 2001.

VINHA, M. Corpo-sujeito Kadiwéu: jogo e esporte. 2004. 273 f. Tese (Doutorado em Educação Física) - Faculdade de Educação Física, Universidade Estadual de Campinas, Campinas, 2004.

VINHA, M. Jogo cabo-de-guerra e a reconquista das terras indígenas de Mato Grosso do Sul. In. LORO, A.P.; VINHA, M.; GOLIN, C.H. Educação Física: enfoques contemporâneous. Dourados: Ed. UFGD, 2013.

VINHA, M. Saúde social: fonte revitalizadora dos povos indígenas. In: FERREIRA, M.B.R.; VINHA, M. Celebrando os jogos, a memória e a identidade: XI Jogos dos Povos Indígenas. Porto Nacional - Tocantis, 2011. Dourados: UFGD, 2015. 272 p.

VINHA, M.; FERREIRA, M.B.R. Esporte entre os índios Kadiwéu. Revista Brasileira Ciências do Esporte, Campinas, v. 24, n. 3, p. 145-158, 2003.

VIVEIROS DE CASTRO, E.B. A fabricação do corpo na sociedade xinguana. In: SEEGER, A., DA MATTA, R. (Orgs.). A construção da pessoa nas sociedades indígenas brasileiras. Rio de Janeiro: Boletim do Museu Nacional, 1979.

XIMENES, L.G. Aquém e além-mar: imaginário e interação entre índios e não índios. In: SIMPÓSIO NACIONAL DE HISTÓRIA, 26., 2011, São Paulo. Anais... São Paulo: AnpuhSP, 2011.

WEED, M. et al. A systematic review of the evidence base for developing a physical activity and health legacy from the London 2012 Olympic and Paralympic games. Canterbury, UK: Centre For Sport, Physical Education \& Activity Research (SPEAR), Canterbury Christ Church University, 2009. Disponível em: <www.canterbury.ac.uk/socialapplied-sciences/>. Acesso em: 17 nov. 2017.

WICKER, P; SOTIRIADOU, P. The trickle-down effect: what population groups benefit from hosting major sport events? International Journal of Event Management Research, Queensland, v. 8, n. 2, p. 25-41, 2013. 
Apêndice A - Tabela completa com os dados coletados sobre a representação dos Jogos dos Povos Indígenas na mídia brasileira 


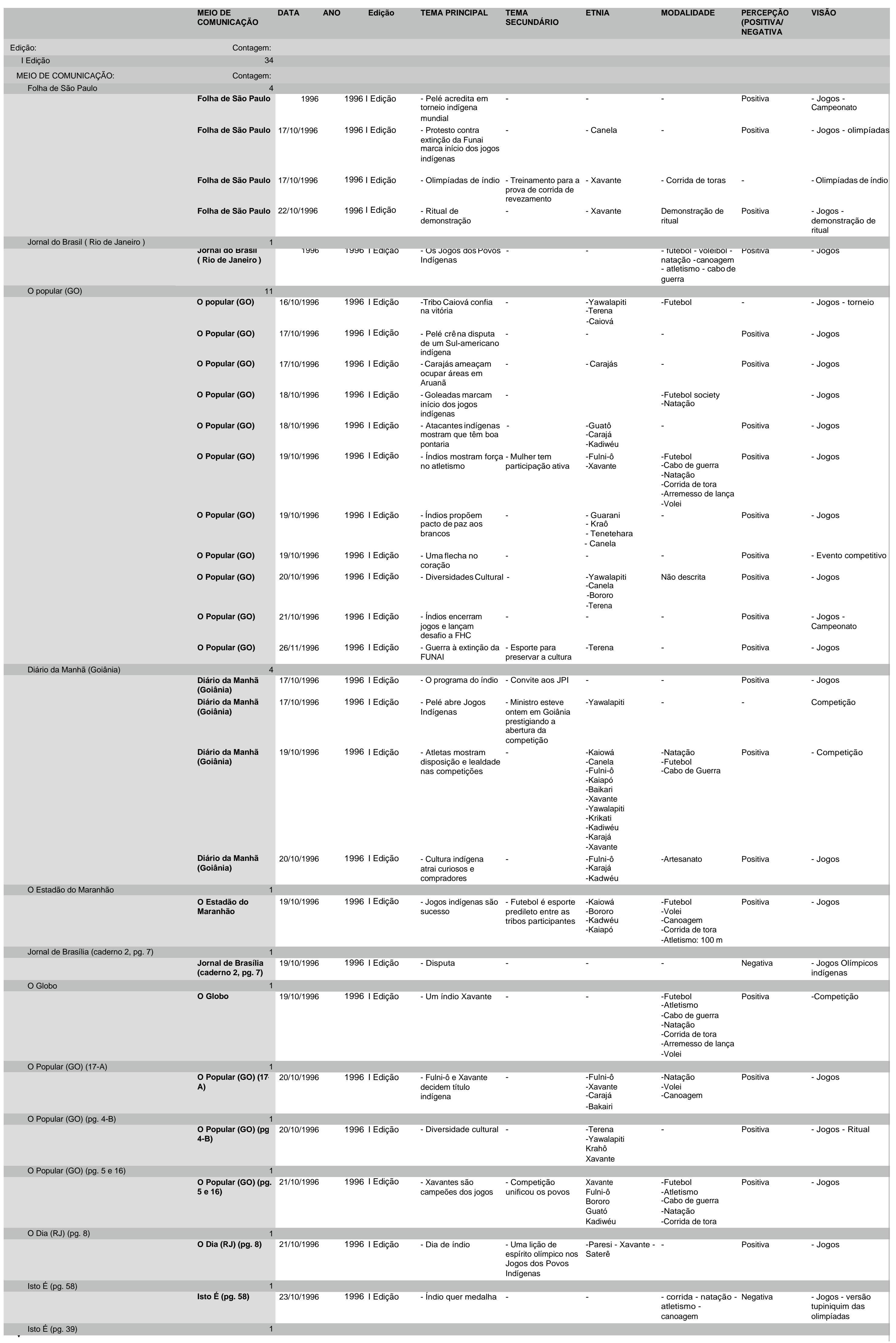




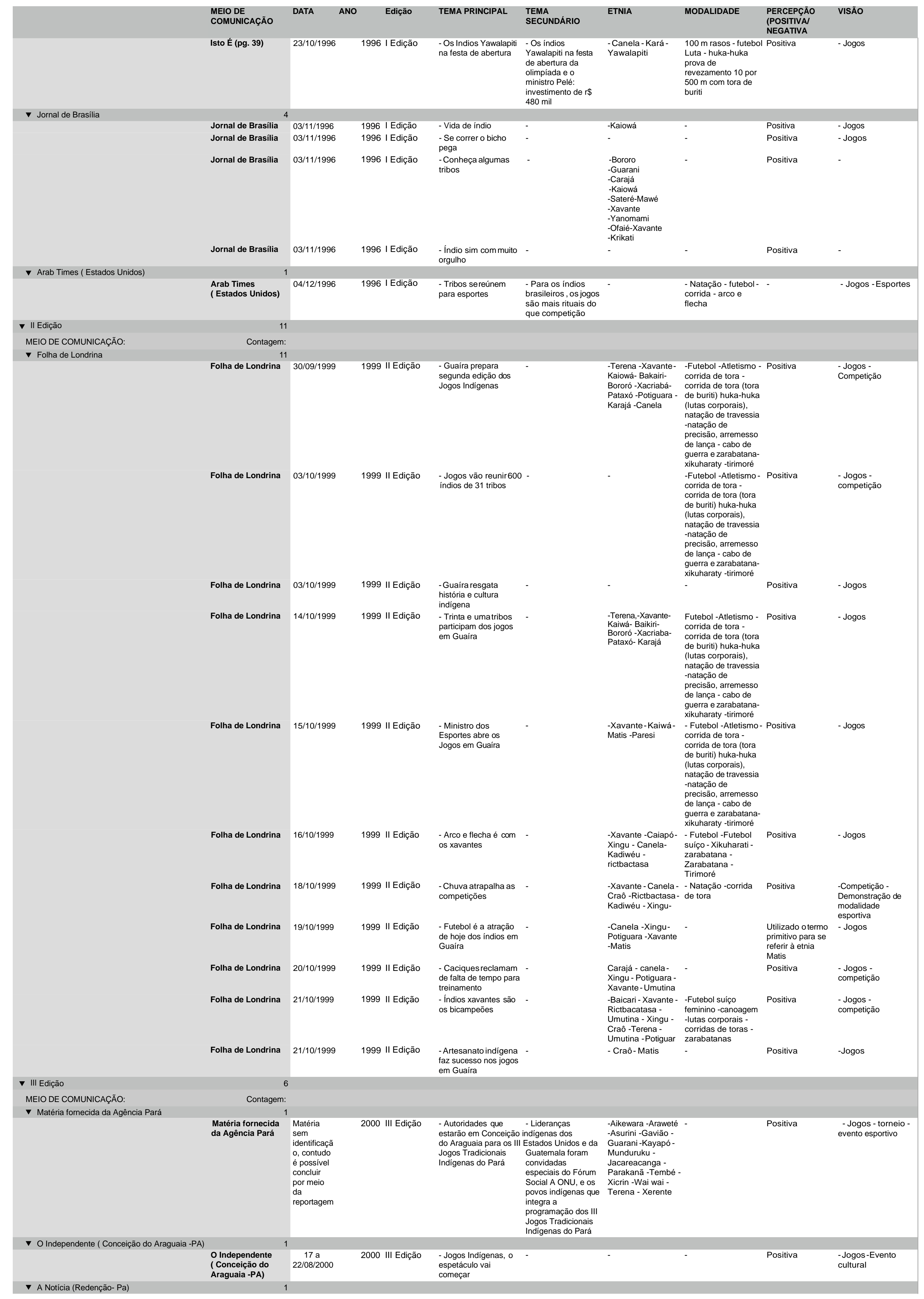




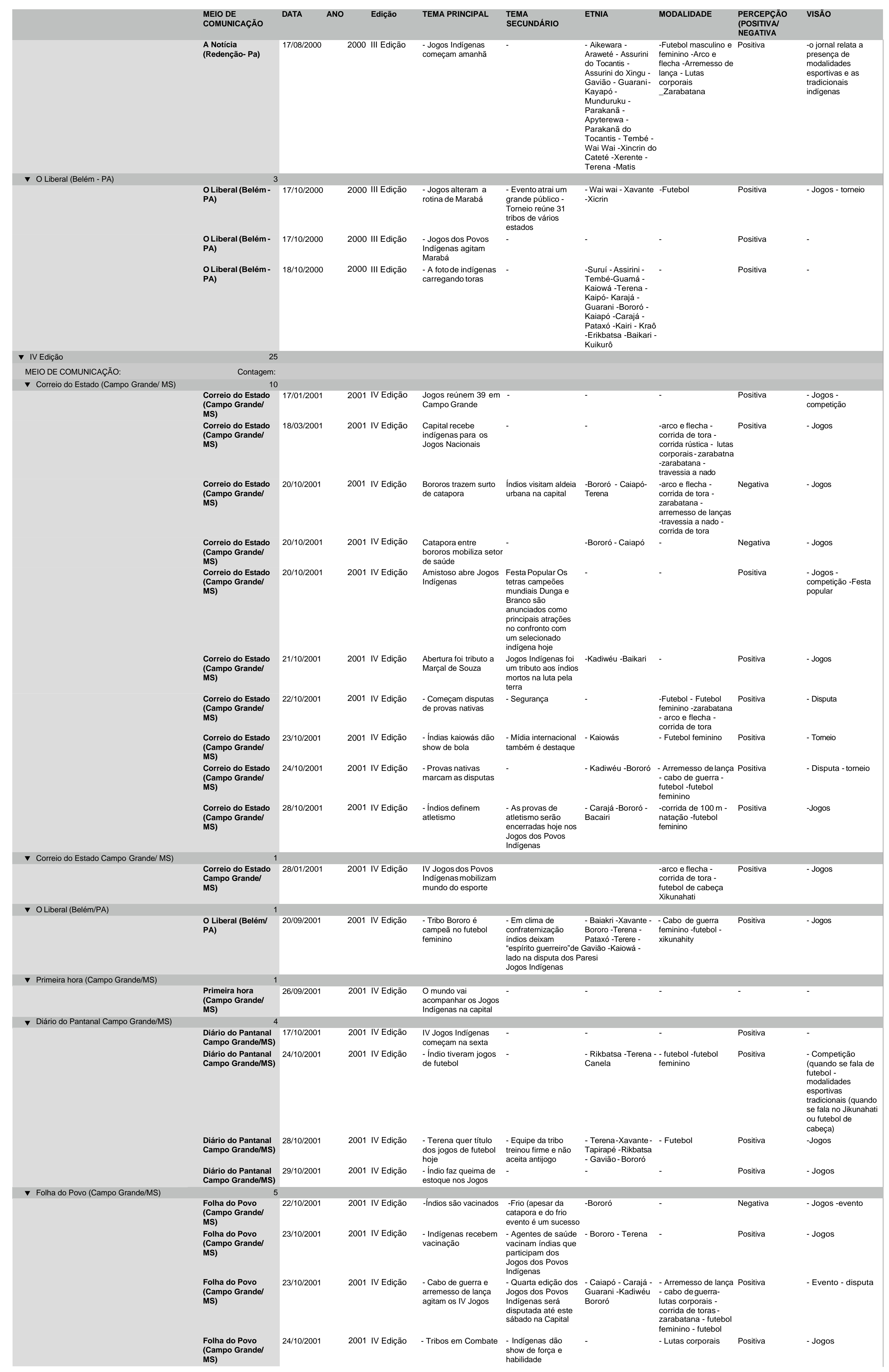




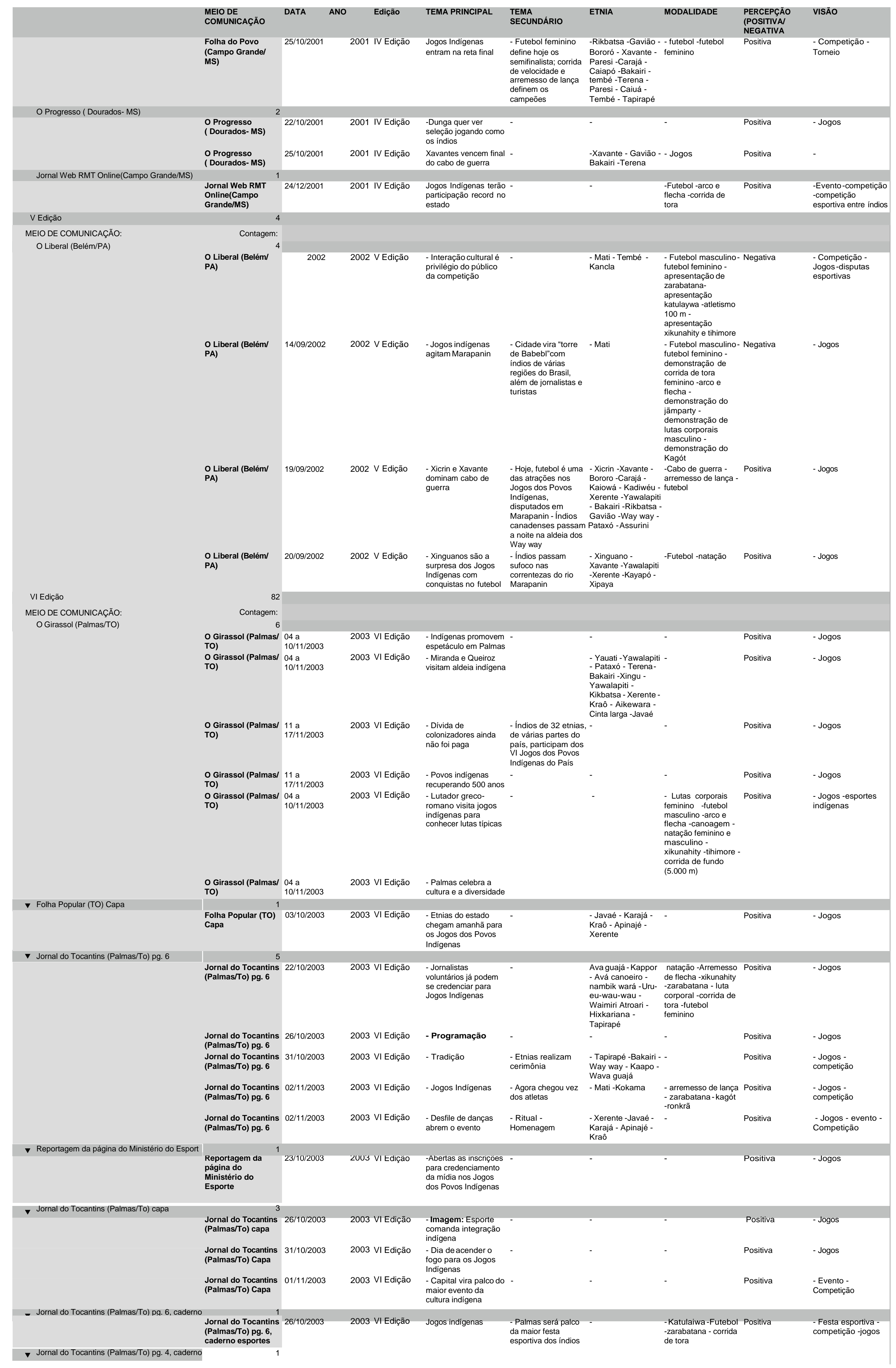




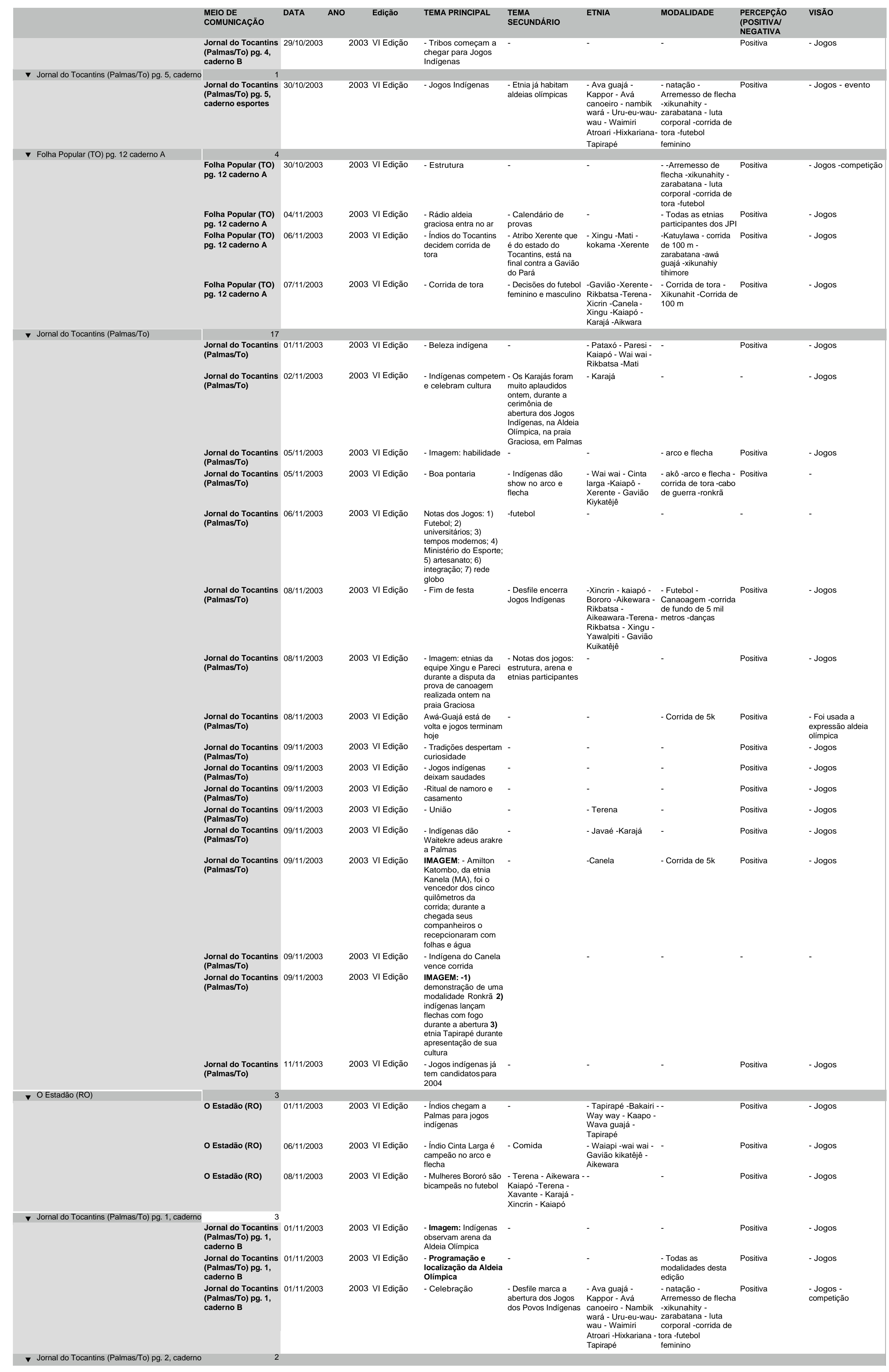




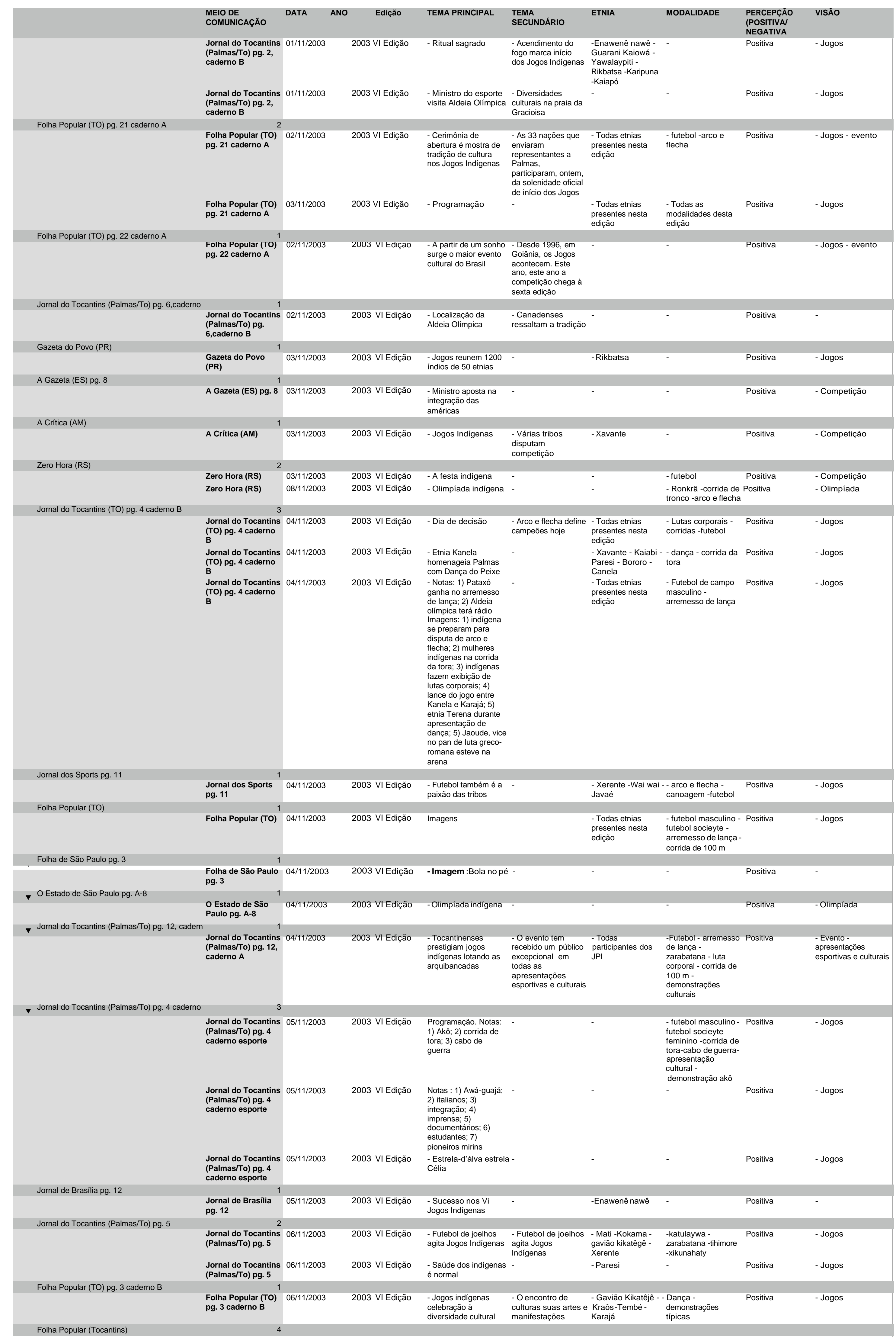




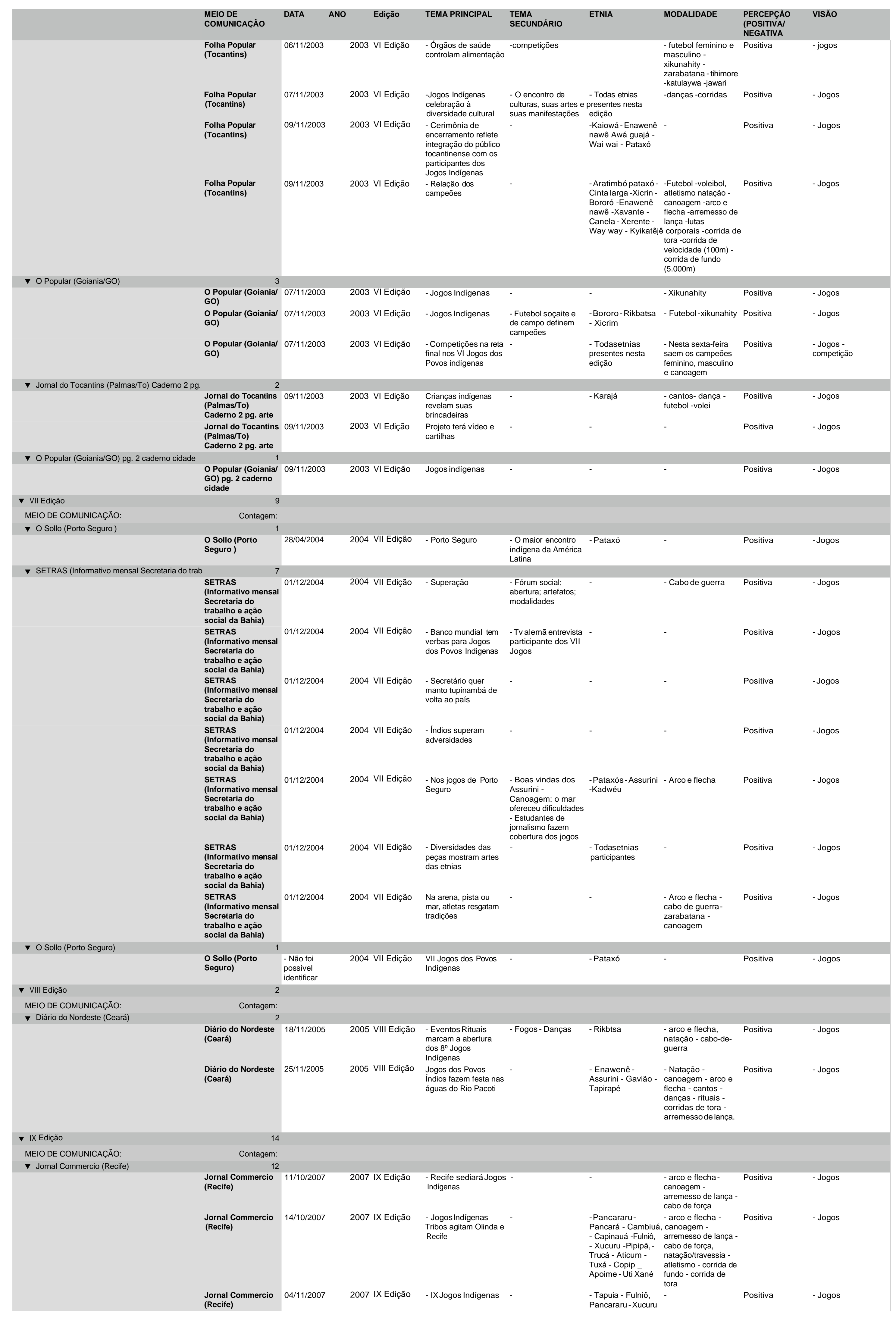




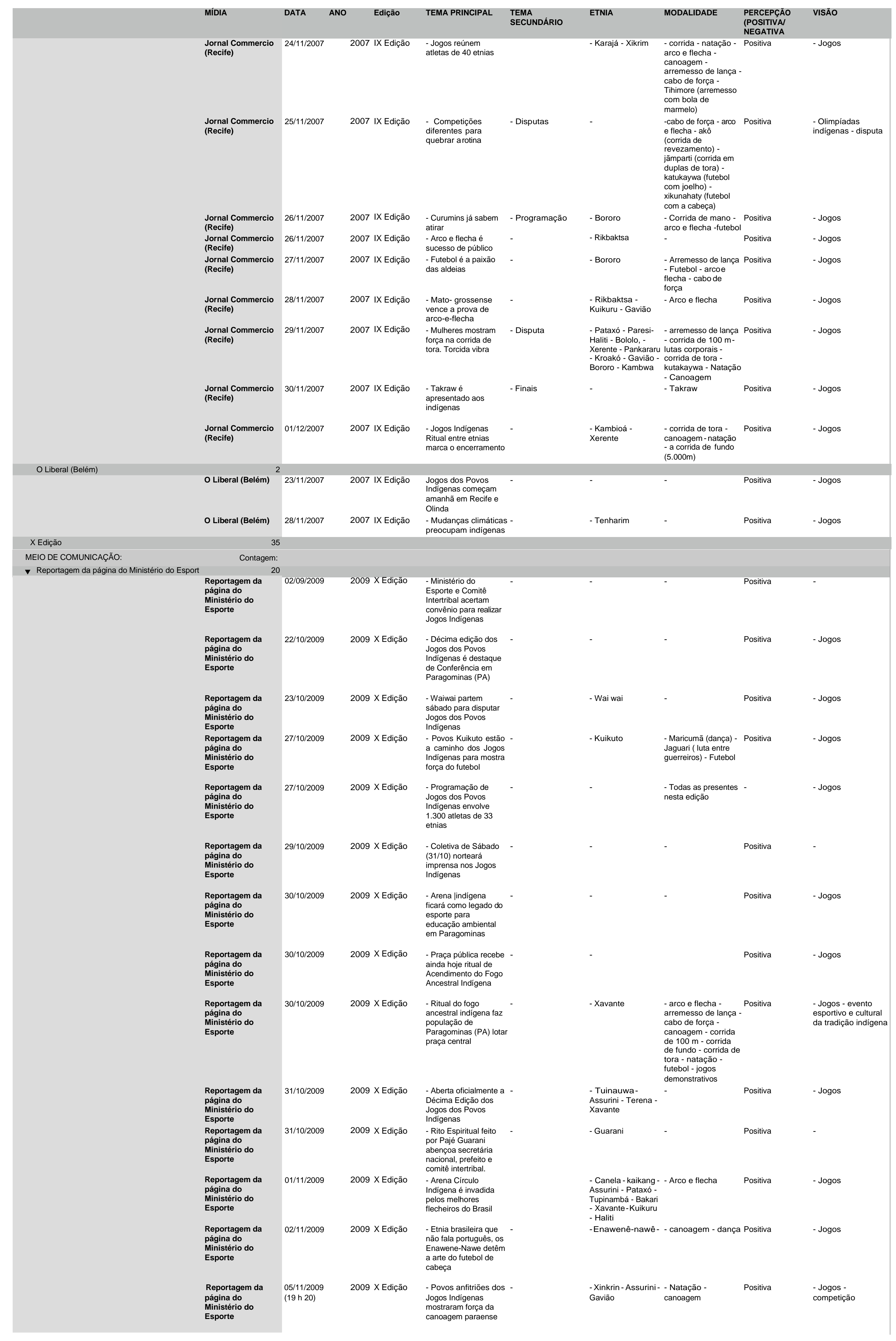




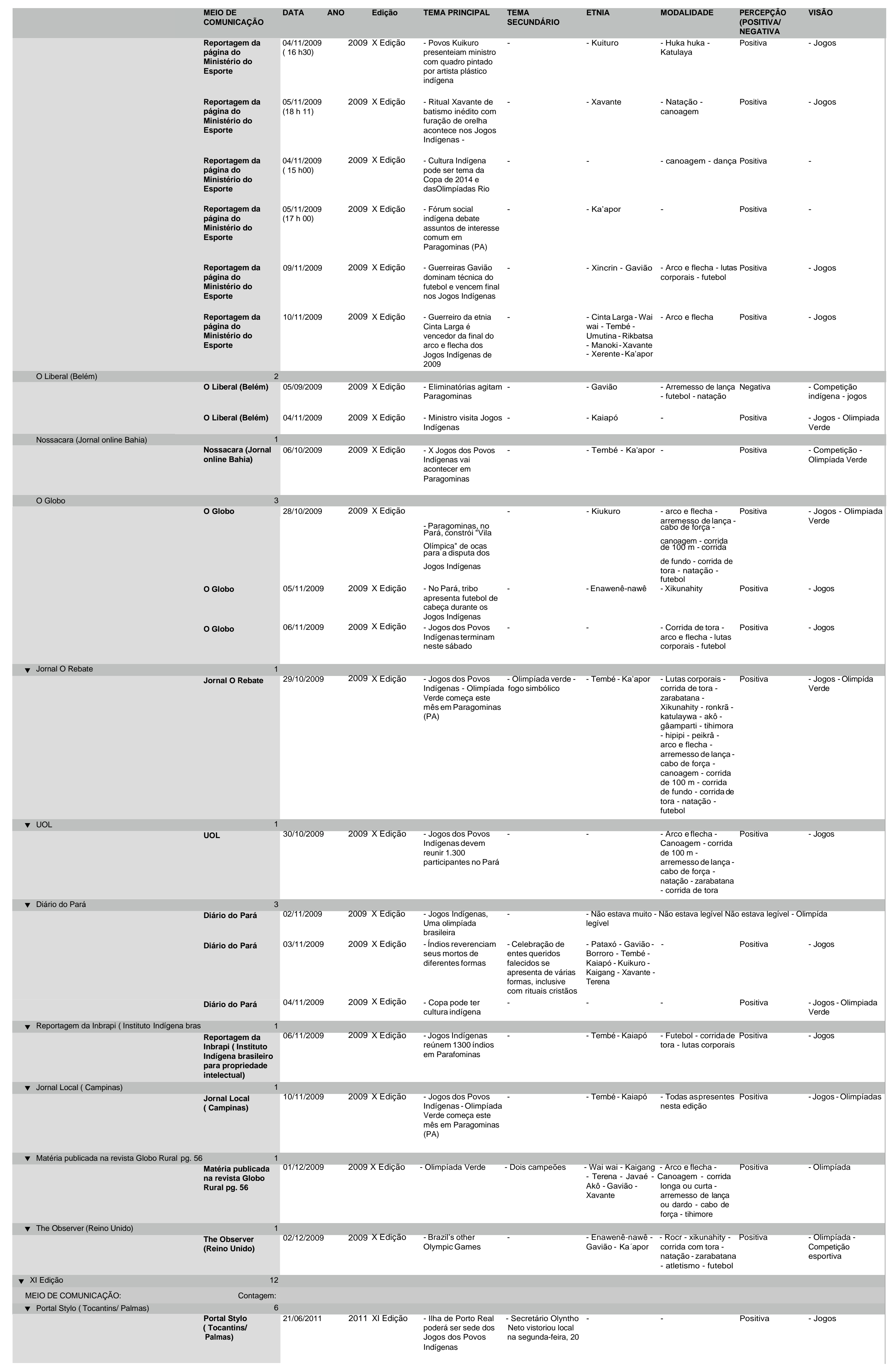




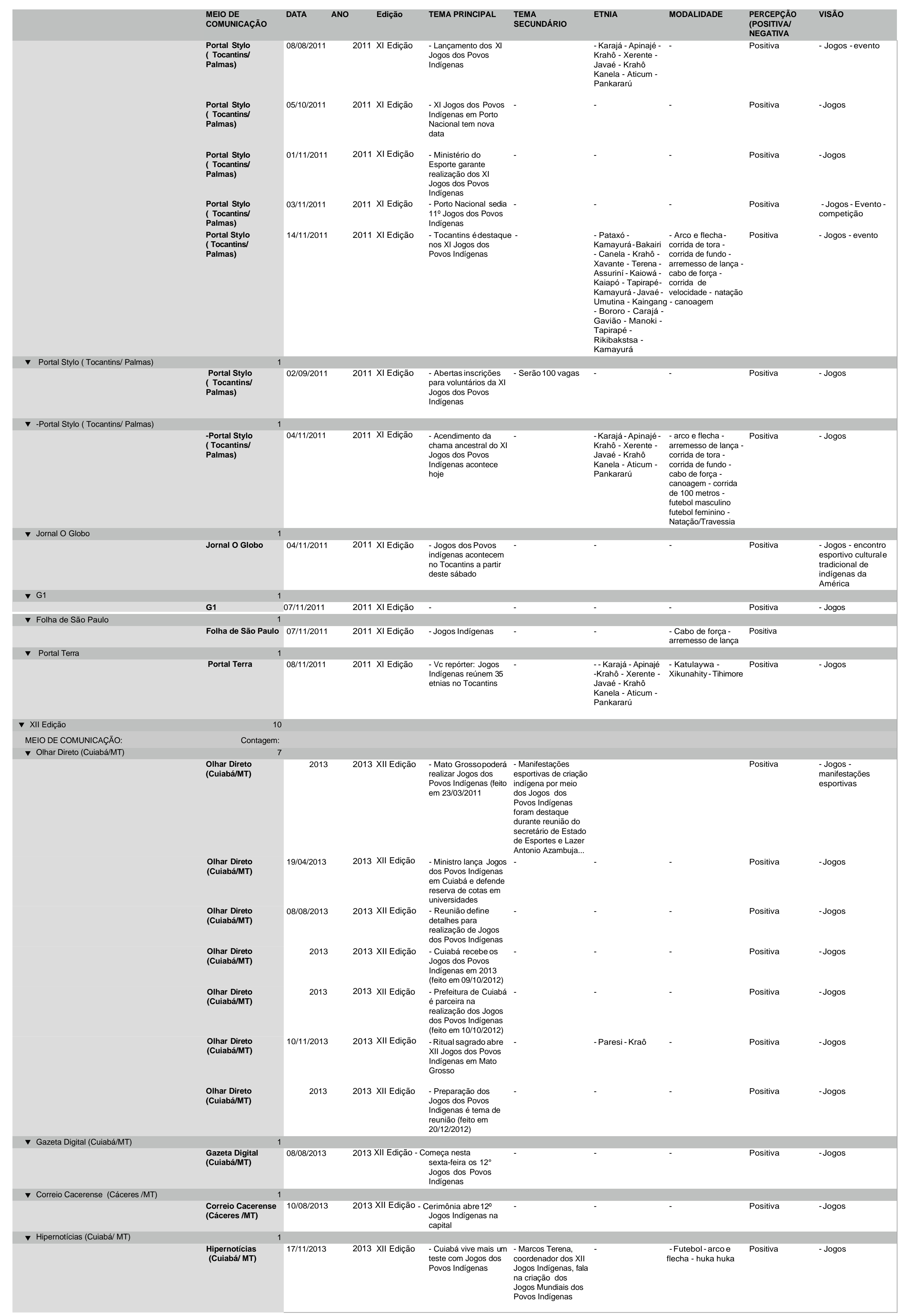

